\title{
Análise e gerenciamento dos efluentes gerados no processo produtivo do combustível nuclear
}

\author{
MAYARA COSTA DE CASTRO BECCA SAKAI
}

Dissertação apresentada como parte dos requisitos para obtenção do Grau de Mestre em Ciências na Área de Tecnologia Nuclear - Materiais

Orientadora:

Profa. Dra. Elita F. Urano de Carvalho 
INSTITUTO DE PESQUISAS ENERGETICAS E NUCLEARES Diretoria de Pesquisa, Desenvolvimento e Ensino

Av. Prof. Lineu Prestes, 2242 - Cidade Universitária CEP: 05508-000 Fone/Fax(0XX11) 3133-8908

SÃO PAULO - São Paulo - Brasil http://www.ipen.br

O IPEN é uma Autarquia vinculada à Secretaria de Desenvolvimento, associada à Universidade de São Paulo e gerida técnica e administrativamente pela Comissão Nacional de Energia Nuclear, órgão do Ministério da Ciência, Tecnologia e Inovação. 


\title{
INSTITUTO DE PESQUISAS ENERGÉTICAS E NUCLEARES
}

Autarquia associada à Universidade de São Paulo

\author{
Análise e gerenciamento dos efluentes gerados no processo produtivo do \\ combustível nuclear \\ Versão Corrigida
}

\section{MAYARA COSTA DE CASTRO BECCA SAKAI}

Dissertação apresentada como parte dos requisitos para obtenção do Grau de Mestre em Ciências na Área de Tecnologia Nuclear - Materiais

Orientadora:

Profa. Dra. Elita F. Urano de Carvalho 
Dedicatória

Ao meu marido e minha família, com muito amor e carinho. 


\section{Agradecimentos}

À Dra. Elita F. U. de Carvalho, pela orientação, ensinamentos e paciência durante o desenvolvimento desse trabalho, e acima de tudo pela confiança depositada em mim desde o princípio.

Aos funcionários do Centro de Combustível Nuclear pela ajuda com informações e esclarecimentos referente ao meu trabalho.

Aos amigos do grupo, pelos momentos de descontração.

À minha mãe, Eliane Maria Santos Cravo Costa de Castro e ao meu pai, Ary Estevam de Castro, agradeço por toda a paciência durante toda a minha caminhada, pelo amor, compreensão, e apoio em todos os momentos.

Agradeço à minha irmã Maysa Costa de Castro, por toda amizade e companheirismo e principalmente pela ajuda, orientação e paciência nos momentos de dúvidas e dificuldades.

Ao meu marido, Caio Henrique Becca Sakai, pelo companheirismo, carinho e dedicação ao longo dos anos, e por me apoiar nessa nova jornada de novos conhecimentos e desafios.

Ao Instituto de Pesquisas Energéticas e Nucleares IPEN-CNEN/USP, na pessoa do Sr. Superintendente, Dr. Wilson Aparecido Parejo Calvo por proporcionar toda a infraestrutura necessária para o desempenho do projeto.

À Coordenação de Aperfeiçoamento de Pessoal de Nível Superior, pela concessão da bolsa de estudos. 


\section{Epígrafe}

"A tarefa não é ver aquilo que ninguém viu, Mas pensar o que ninguém ainda pensou Sobre aquilo que todo mundo vê." Arthur Schopenhauer 


\section{Resumo}

O Brasil com o propósito de se tornar autossuficiente na produção de radioisótopos e fontes radioativas usados na medicina nuclear, na agricultura e no meio ambiente desenvolveu o projeto de um reator multipropósito de 30 megawatts de potência para atender a demanda nacional. No Instituto de Pesquisas Energéticas e Nucleares (IPEN), o Centro de Combustível Nuclear (CCN) é responsável pela fabricação dos combustíveis para o reator IEA-R1 e, possivelmente, pelos combustíveis do reator multipropósito. Com o intuito de atender a demanda para os reatores foi projetada uma nova planta de fabricação com a capacidade máxima de 60 combustíveis por ano, o qual atualmente é de dez. $O$ aumento da produção consequentemente aumentará o volume de efluentes gerados. A atual preocupação com o meio ambiente faz-se necessário elaborar um plano de gestão para tornar o processo sustentável, o qual ocasionará em benefícios ambientais, econômicos e sociais. O processo produtivo do combustível gera vários tipos de efluentes, contendo urânio ou não, sendo sólidos, líquidos e gasosos com características físicas e químicas variadas. Esse estudo tem como objetivo identificar, caracterizar e segregar os efluentes gerados em todo o processo produtivo de obtenção do combustível nuclear do tipo MTR (Materials Testing Reactors). No desenvolvimento do presente trabalho foram utilizadas como base a Resolução no 357 , de 17 de março 2005, e a Resolução № 430, de 13 de maio de 2011 do Conselho Nacional do Meio Ambiente - CONAMA. Com os resultados obtidos foi possível determinar que os efluentes líquidos são os principais aspectos que podem causar contaminação ao meio ambiente, e a atual situação do CCN mostra que $30 \%$ do efluente líquido possui tratamento de recuperação de urânio; $20 \%$ dos efluentes líquidos são reutilizados na composição química em que foi gerado; $35 \%$ descartado diretamente ao meio ambiente de acordo com a legislação. 0 restante dos efluentes líquidos, cerca de $15 \%$, estão em fase de desenvolvimento do processo de tratamento.

Palavras-chave: efluentes, ciclo combustível, combustível nuclear, urânio. 


\begin{abstract}
Brazil with the purpose of becoming self-sufficient in the production of radioisotopes and radioactive sources used in nuclear medicine, agriculture and the environment has developed the project of a multipurpose reactor of 30 megawatts of power to meet the national demand. At the Instituto de Pesquisas Energéticas e Nucleares (IPEN), the Centro de Combustível Nuclear (CCN) is responsible for manufacturing fuels for the IEA-R1 reactor and, possibly, the multipurpose reactor fuels. In order to meet the demand for the reactors, a new manufacturing plant with a maximum capacity of 60 fuels per year has been designed, which is currently ten. The increase in production will consequently increase the volume of effluents generated. The current concern with the environment makes it necessary to elaborate a management plan to make the process sustainable, which will lead to environmental, economic and social benefits. The production process of the fuel generates several types of effluents - containing uranium or not - being solid, liquid and gaseous with varied physical and chemical characteristics. This study aims to identify, characterize and segregate the effluents generated in the entire production process of obtaining the nuclear fuel type MTR (Materials Testing Reactors). In the development of this paper, Resolution 357 of March 17, 2005, and Resolution No. 430 of May 13, 2011 of the National Environmental Council - CONAMA, were used. With the results obtained it was possible to determine that the liquid effluents are the main aspects that can cause contamination to the environment, and the current situation of the CCN shows that $30 \%$ of the liquid effluent has uranium recovery treatment; $20 \%$ of the liquid effluents are reused in the chemical composition in which it was generated; $35 \%$ discarded directly to the environment according to the legislation. The rest of the liquid effluents, about 15\%, are in the development phase of the treatment process.
\end{abstract}

Keywords: effluents, fuel cycle, nuclear fuel, uranium. 


\section{Lista de Figuras}

Figura 2.1 Mapa do IPEN com as instalações do CCN.............................. 20

Figura 2.2 Diagrama de blocos do processo de produção do EC................ 23

Figura 2.3 Esquema de montagem da placa combustível.......................... 28

Figura 4.1 Efluentes gerados no processo de produção do EC...................59

Figura 4.2 Diagrama geral do processo de produção do EC. …….............. 72

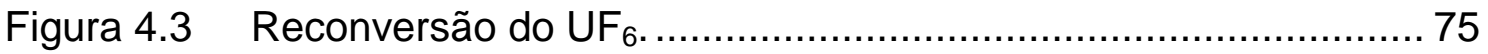

Figura 4.4 Processamento de ligas especiais - parte 1 1............................ 76

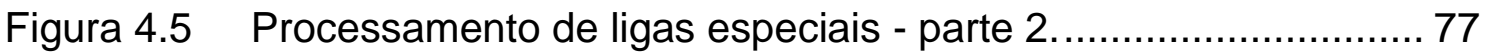

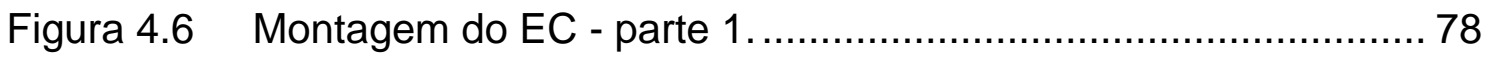

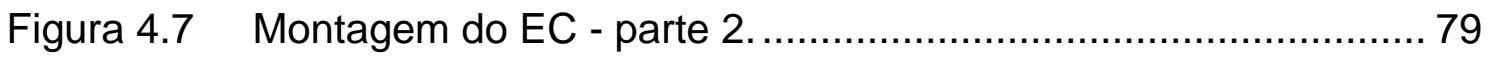

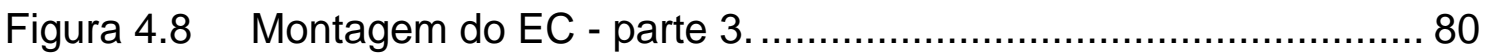

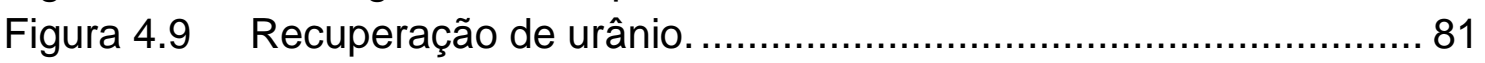

Figura 4.10 Tratamento dos efluentes contendo urânio............................... 82

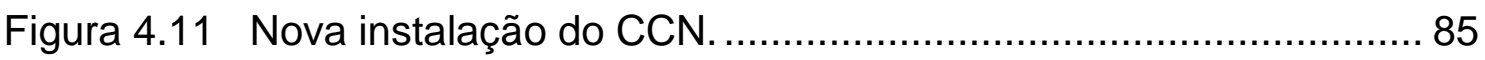




\section{Lista de Tabelas}

Tabela 2.1: Áreas do $\mathrm{CCN}$ e suas respectivas atividades. ......................... 21

Tabela 2.2 Normas ISO existentes e seus status. .................................. 32

Tabela 2.3 Índice de severidade de impactos ambientais......................... 39

Tabela 2.4 Índice de ocorrência de impactos ambientais. ......................... 39

Tabela 2.5 Índice de deteç̧ão de impactos ambientais........................... 39

Tabela 2.6 Índice de abrangência de impactos ambientais. ..................... 40

Tabela 2.7 Planilha de identificação de aspectos e impactos

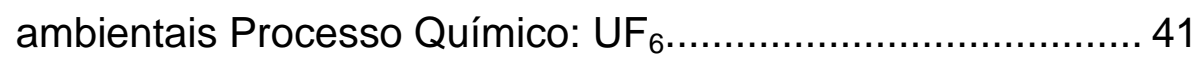

Tabela 2.8 Planilha de identificação de aspectos e impactos ambientais Processo Ligas Especiais. ..................................... 42

Tabela 2.9 Planilha de identificação de aspectos e impactos ambientais Processo Mecânico-Metalúrgico. ........................... 43

Tabela 2.10 Planilha de identificação de aspectos e impactos ambientais Processo Químico: Recuperação de Urânio......... 44

Tabela 2.11 Planilha de identificação de aspectos e impactos ambientais Processo Administrativo......................................... 45

Tabela 3.1 Análises realizas no CQMA................................................. 58

Tabela 4.1 Efluentes gerados no processo de produção do EC. .............. 60

Tabela 4.2 Análises utilizadas na caracterização dos efluentes. ............... 61

Tabela 4.3 Efluentes líquidos gerados no processo produtivo do EC....... 62

Tabela 4.4 Efluentes gasosos gerados no processo produtivo do EC...... 64

Tabela 4.5 Efluentes sólidos gerados no processo produtivo do EC........66 66 


\section{Lista de Siglas}

A - Abrangência

AIA - Avaliação de Impacto Ambiental

APR - Advanced Power Reactor

CCL - Processamento de Ligas Especiais

CCN - Centro de Combustível Nuclear

CCP - Processamento Mecânico-Metalúrgico

CCR - Processamento Químico

CEN - Centro de Energia Nuclear

CNEN - Comissão Nacional de Energia Nuclear

$\mathrm{CNPq}$ - Conselho Nacional de Pesquisas

CONAMA - Conselho Nacional do Meio Ambiente

CQMA - Centro de Química e Meio Ambiente

CTMSP - Centro Tecnológico da Marinha de São Paulo

D - Detecção

DUA - Diuranato de amônio

EC - Elemento Combustível

EUA - Estados Unidos da América

FMEA - Failure Mode and Effect Analysis

FPM - Fabricação de Placas e Montagem do EC

IEA - Instituto de Energia Atômica

IPEN - Instituto de Pesquisas Energéticas e Nucleares

IRA - Índice de Risco Ambiental

$\mathrm{L}$ - Critério adicional

MCP - Metrologia e Controle de Processo

MIT - Massachusetts Institute of Technology

MTR - Materials Testing Reactor

NA - National Academies

NRC - NUCLEAR Regulatory Commission

O - Ocorrência 
PPB - Processamento de Pós e Briquetes

$\mathrm{RC}$ - Reconversão do $\mathrm{UF}_{6}$

RF - Redução e Fusão de Ligas

RMB - Reator Multipropósito Brasileiro

RU - Recuperação de Urânio

S - Severidade

SGA - Sistema de Gestão Ambiental

TBP - Tributil fosfato

TEI - Tratamento de Efluentes Industriais

USP - Universidade de São Paulo 


\section{Sumário}

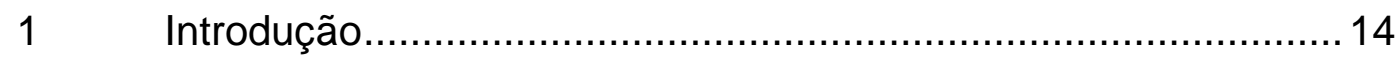

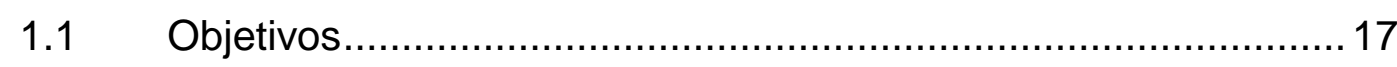

2 Revisão da Literatura.................................................... 18

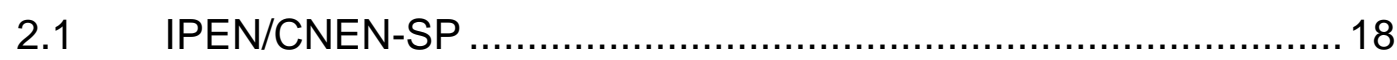

2.2 Combustível Nuclear Produzido no IPEN/CNEN-SP .................. 19

2.3 Processo de Produção do Combustível Nuclear ........................21

2.3.1 Processamento Químico ............................................ 23

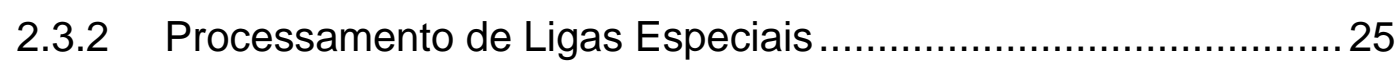

2.3.3 Processamento Mecânico-Metalúrgico ...................................26

2.4 Questão Ambiental .................................................... 29

2.5 Legislação de Interesse ................................................ 34

2.6 Impactos Ambientais que o CCN pode causar ..........................37

2.7 Gerenciamento de Efluentes ............................................. 46

2.7.1 Gerenciamento de Efluentes em Plantas Nucleares ..................49 49

$3 \quad$ Materiais e Métodos ........................................................ 57

3.1 Caracterização química dos efluentes gerados no processo produtivo .................................................................... 58

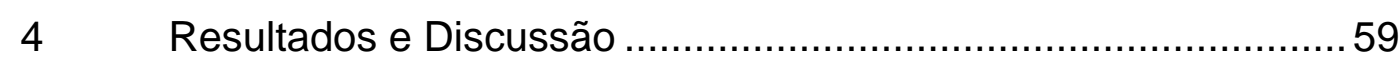

4.1 Avaliação dos efluentes gerados no processo produtivo do elemento combustível............................................................59

4.2 Caracterização química dos efluentes gerados no processo produtivo ..................................................................... 60

4.3 Fluxograma do processo produtivo.................................... 73

$4.4 \quad$ Nova instalação do CCN ................................................... 83

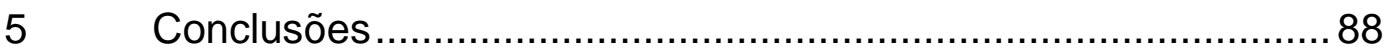

$6 \quad$ Referências Bibliográficas .............................................90 


\section{Introdução}

Durante muitos anos, o IPEN-CNEN/SP trabalhou no desenvolvimento do processo de fabricação de elementos combustíveis usados internacionalmente em reatores de pesquisas, visando a nacionalização da sua produção para utilização no seu reator IEA-R1. Desde sua inauguração em 1956 e durante quase três décadas, ao longo de uma época de incertezas quanto ao mercado de materiais nucleares, o reator IEA-R1 dependeu totalmente da importação dos elementos combustíveis necessários para sua operação, fornecidos durante este período pela GENERAL ATOMICS americana (93\% em $\left.{ }^{235} \mathrm{U}\right)$ e NUKEM (20\% em $\left.{ }^{235} \mathrm{U}\right)$ [1].

Considerando-se a importância social e estratégica da produção de radiofármacos no país e o contínuo crescimento de dispêndios na importação dos radioisótopos necessários para atender a essa produção o Ministério da Ciência, Tecnologia e Inovação estabeleceu como meta em seu Plano de Ação em 2007 [2] a construção de um reator multipropósito, com o intuito de tornarse autossuficiente na produção de radiofármacos.

Atualmente, são realizados mais 2 milhões de procedimentos envolvendo radiofármacos no Brasil [3]. Radiofármaco é uma substância com afinidade biológica conhecida cuja molécula possui ao menos um átomo radioativo (radioisótopo), pode ser empregado na Medicina Nuclear tanto para diagnóstico (95\%) quanto para terapia (5\%) [4]. Em sua maioria os radioisótopos são importados gerando um gasto de pelo menos US\$ 15 milhões por ano [5].

Esse contexto determinou a necessidade de implantação de uma nova unidade de produção no Centro do Combustível Nuclear (CCN), planejada para utilizar $\mathrm{U}_{3} \mathrm{Si}_{2}$ na fabricação dos elementos combustíveis [6]. Esta nova instalação foi idealizada para ampliar a capacidade atual de elementos combustíveis tipo MTR (Material Testing Reactor - combustível plano a base de dispersão).

O novo reator, denominado de Reator Multipropósito Brasileiro (RMB), será de grande porte com 30 megawatts de potência, e terá três funções 
principais: fornecer radioisótopos para aplicação na saúde, indústria, meio ambiente e agricultura; criar capacidade nacional para testar e qualificar materiais e combustíveis nucleares e facilitar a instalação de um laboratório nacional de pesquisa com feixes de nêutrons [2].

O CCN, localizado no IPEN, a cerca de 30 anos é o único fornecedor nacional de combustíveis para reatores de pesquisa. Sendo assim será o responsável pela fabricação dos combustíveis nucleares para o novo reator. A capacidade atual do CCN é cerca de dez combustíveis ao ano, e para atender a nova demanda foi projetada uma planta que possibilitará a produção máxima de 60 combustíveis ao ano.

A nova instalação operará de modo integrado, na qual todas as atividades de fabricação serão realizadas sob um plano mais coerente, tendo origem na reconversão do $U_{6}$ até a montagem final do elemento combustível.

As atividades realizadas no $\mathrm{CCN}$ envolvem a manipulação e o processamento de hexafluoreto de urânio $\left(\mathrm{UF}_{6}\right)$, na forma gasosa, fluoreto de uranila $\left(\mathrm{UO}_{2} \mathrm{~F}_{2}\right)$, nitrato de uranilo $(\mathrm{NU})$, na forma líquida, tetrafluoreto de urânio $\left(\mathrm{UF}_{4}\right)$, urânio metálico $\left(\mathrm{U}^{\circ}\right)$, trióxido de urânio $\left(\mathrm{UO}_{3}\right)$, diuranato de amônio (DUA) e siliceto de urânio $\left(\mathrm{U}_{3} \mathrm{Si}_{2}\right)$, na forma sólida.

A manipulação destas substâncias gera, inevitavelmente, efluentes líquidos, sólidos e gasosos e rejeitos radioativos, que são característicos dos processos desenvolvidos nesta instalação. Esses materiais são controlados visando a proteção de trabalhadores, indivíduos do público e do meio ambiente.

O crescimento da atividade, com caráter industrial, com consequente geração de maior quantidade de efluentes e poluentes, tem forçado o desenvolvimento de novas tecnologias para os processos produtivos, simultaneamente à necessidade de novas técnicas administrativas voltadas ao gerenciamento dessas atividades, com preocupação ambiental. Ao mesmo tempo em que os governos passaram a dedicar-se à busca de soluções para problemas ambientais, organismos normalizadores passaram a trabalhar em normas técnicas de orientação às empresas, visando o desenvolvimento de uma melhoria contínua. 
A produção do elemento combustível gera vários tipos efluentes (contendo urânio ou não) com características físicas e químicas diferentes. Esses efluentes devem ser tratados, recuperados devendo retornar ao processo produtivo, entre eles podemos destacar os efluentes como soluções aquosas, como os gerados na obtenção de $\mathrm{UF}_{4}$, DUA, refugos sólidos na forma de pó como $\mathrm{U}_{3} \mathrm{Si}_{2}$ contaminados, escórias de $\mathrm{MgF}_{2}$ proveniente da redução de $\mathrm{UF}_{4}$ a urânio metálico, placas e briquetes refugados da produção e montagem do elemento combustível assim como restos de amostras utilizadas em análises de controle e efluentes líquidos gerados em análises de metalografia.

A preocupação com o meio ambiente existe desde do início da elaboração da Constituição Brasileira de 1988, na qual em seu artigo 225 expõe seu receio: "Todos têm direito ao meio ambiente ecologicamente equilibrado, bem de uso comum do povo e essencial à sadia qualidade de vida, impondo-se ao Poder Público e à coletividade o dever de defende-lo e preservá-lo para a presentes e futuras gerações". A partir de então teve-se um aumento da preocupação com o meio ambiente, surgiram normas com 0 objetivo de fiscalizar as empresas e reduzir os impactos ao meio ambiente. Mas, com o decorrer dos anos, a preocupação das empresas com multas e autuações referentes as legislações não seguidas passaram a ficar em segundo plano e vem sendo substituídas por um maior cuidado com a imagem da empresa.

Foi nesse contexto que se desenvolveu a gestão ambiental, um conjunto de ações que envolvem políticas públicas, o setor produtivo e a sociedade de forma a incentivar o uso racional e sustentável dos recursos ambientais. É um processo que liga as questões de conservação e do desenvolvimento em todos os níveis.

Considerando a evolução histórica da preocupação com o meio ambiente até o então desenvolvimento da gestão ambiental, busca-se com esse trabalho identificar, caracterizar e segregar os efluentes gerados no processo produtivo do combustível nuclear para que futuramente o centro seja capaz de gerenciar e controlar seus efluentes. E para avaliar todos os aspectos possíveis realizouse um aprofundamento no estudo da legislação ambiental, onde é possível destacar duas resoluções importantes relativas à lançamento de efluentes ao 
meio ambiente, tais como a Resolução № 357, de 17 de março 2005, e a Resolução no 430, de 13 de maio de 2011 do Conselho Nacional do Meio Ambiente - CONAMA.

\subsection{Objetivos}

O objetivo principal desse trabalho foi identificar, caracterizar e segregar os efluentes que são gerados durante todo o processo produtivo de obtenção do combustível nuclear, em consonância de segurança e saúde ambiental da instituição e da Unidade de Negócio ( $\mathrm{CCN}$ ) atendendo inclusive as normas CNEN-NE-1.04 [7], CONAMA N²37[8].

Para que o objetivo principal seja cumprido, estabeleceu-se os seguintes objetivos específicos:

1. Conhecer e acompanhar o processo de fabricação do combustível nuclear;

2. Quantificar todas as emissões geradas no processo produtivo de elemento combustível do tipo MTR;

3. Caracterizar química e fisicamente todas as emissões líquidas, sólidas e gasosas geradas no processo produtivo de elemento combustível nuclear;

4. Avaliar os efluentes quanto à legislação de meio ambiente;

5. Segregar os efluentes de modo a agrupar os que requerem o mesmo tratamento, separando-os dos que requerem tratamentos específicos;

6. Estudar processos alternativos de tratamento de efluentes, em relação aos já implantados no $\mathrm{CCN}$.

7. Construir um fluxograma do processo produtivo do combustível nuclear. 


\section{Revisão da Literatura}

\subsection{IPEN/CNEN-SP}

As aplicações de energia nuclear no Brasil iniciaram-se por volta dos anos 50 quando a Universidade de São Paulo (USP) e o Conselho Nacional de Pesquisas (CNPq) firmaram um convênio com o intuito de criar um órgão nacional para atuar nas áreas de pesquisas científicas, desenvolvimento tecnológico e formação de especialistas nas aplicações pacíficas da energia nuclear. Com isso, surgiu o Instituto de Energia Atômica (IEA) e, logo em seguida, deu início a construção do prédio no qual iria alocar o primeiro reator nuclear: IEA-R1. Esse reator foi doado pelo governo do Estados Unidos da América (EUA) a partir do programa Átomos para a Paz [9].

Em 1979 a IEA passou a se chamar Instituto de Pesquisas Energéticas e Nucleares (IPEN) e foi vinculada à Secretaria da Indústria, Comércio, Ciência e Tecnologia do Governo do Estado de São Paulo na forma de autarquia estadual e, então passou a ser gerida técnica e administrativamente pela Comissão Nacional de Energia Nuclear [9].

O IPEN/CNEN-SP é uma instituição de pesquisa que oferece serviços e produtos ligados à área nuclear. Os setores em que o IPEN/CNEN-SP atua possibilita estender os benefícios da energia nuclear a segmentos maiores de nossa população, pois a multidisciplinaridade que caracteriza as atividades deste setor tem permitido ao instituto conduzir um amplo e variado programa de pesquisa e desenvolvimento em outras áreas. Em especial, decorrente da competência adquirida com a contribuição decisiva no ciclo do combustível nuclear realizado pelo CCN [6].

O CCN é responsável pela produção do combustível nuclear para a operação do reator IEA-R1 e também tem como objetivo o desenvolvimento de novas tecnologias de combustível nuclear [10]. A produção dos EC para reatores de pesquisa iniciou-se na década de 1980 devido à dificuldade de se obter esse combustível no mercado internacional e da necessidade de manter o reator do IPEN/CNEN-SP em operação. Como resultado do esforço de 
capacitação, em setembro de 1988 foi inserido no núcleo do reator o primeiro elemento combustível produzido pelo IPEN/CNEN-SP e desde então, o instituto vem produzindo o combustível necessário para sua operação [11].

Os principais propósitos do $\mathrm{CCN}$ consistem em:

- Desenvolver tecnologias de fabricação de elementos combustíveis para aplicação em reatores de pesquisa tipo piscina;

- Suprir continuamente de combustíveis os reatores de pesquisa do IPEN/CNEN-SP (combustível plano base de dispersão);

- Desenvolver processos e produtos nas áreas do combustível nuclear, com excelência de qualidade, buscando avanços tecnológicos e auxílio à formação de recursos humanos em nível de pós-graduação.

\subsection{Combustível Nuclear Produzido no IPEN/CNEN-SP}

O CCN é responsável pela produção do combustível nuclear para o reator IEA-R1, o elemento combustível produzido é do tipo MTR em forma de placas. Esse tipo de combustíveis apresenta um núcleo que é composto por materiais físseis e férteis; no caso do combustível produzido pelo $\mathrm{CCN}$ o material físsil utilizado é o urânio. Esses combustíveis apresentam um revestimento de modo a garantir a sua integridade e estabilidade estrutural, esse é composto por uma liga de aço inoxidável [10].

O EC se baseia na dispersão de siliceto de urânio $\left(\mathrm{U}_{3} \mathrm{Si}_{2}\right)$ em alumínio com uma densidade de $3 \mathrm{gUcm}^{-3}$. O CTMSP é o fornecedor de urânio, hexafluoreto de urânio $\left(\mathrm{UF}_{6}\right)$ o qual possui um enriquecimento de 19,75 \pm $0,20 \%$ em peso do isótopo ${ }^{235} \mathrm{U}$.

Atualmente no $\mathrm{CCN}$, após muito estudo e desenvolvimento, uma nova carga de combustível tipo MTR foi fabricada para o Reator IPEN MB01, que consiste de uma unidade crítica projetada e construída pelo IPEN/CNEN-SP em parceria com a Marinha (COPESP - atual CTMSP). O CTMSP está operando desde 1988 e é uma instalação essencial ao grupo de física de 
reatores para análise dos reatores de potência de geração elétrica ou propulsão naval. Possui desde sua primeira criticalidade, um núcleo com varetas combustíveis de dióxido de urânio $\left(\mathrm{UO}_{2}\right)$ enriquecido a 4,3\%. Esse núcleo será substituído por um núcleo de placas combustíveis de $\mathrm{U}_{3} \mathrm{Si}_{2}-\mathrm{Al}$ com $19,75 \pm 0,20 \%$ em peso de ${ }^{235} \mathrm{U}$ em enriquecimento, para ser semelhante ao núcleo do RMB.

O processo de fabricação dos elementos combustíveis no $\mathrm{CCN}$ é realizado em três áreas distintas em diferentes prédios:

- Processamento Químico (CCR) - Prédio 31(A);

- Processamento de Ligas Especiais (CCL) - Prédio 24(C).

- Processamento Mecânico Metalúrgico (CCP) - Prédio 97(B);

Os três prédios estão localizados fisicamente no IPEN/CNEN-SP de acordo com o mapa a seguir na Figura 2.1. E na Tabela 2.1 temos as subáreas e suas respectivas atividades.

Figura 2.1 Mapa do IPEN com as instalações do CCN.

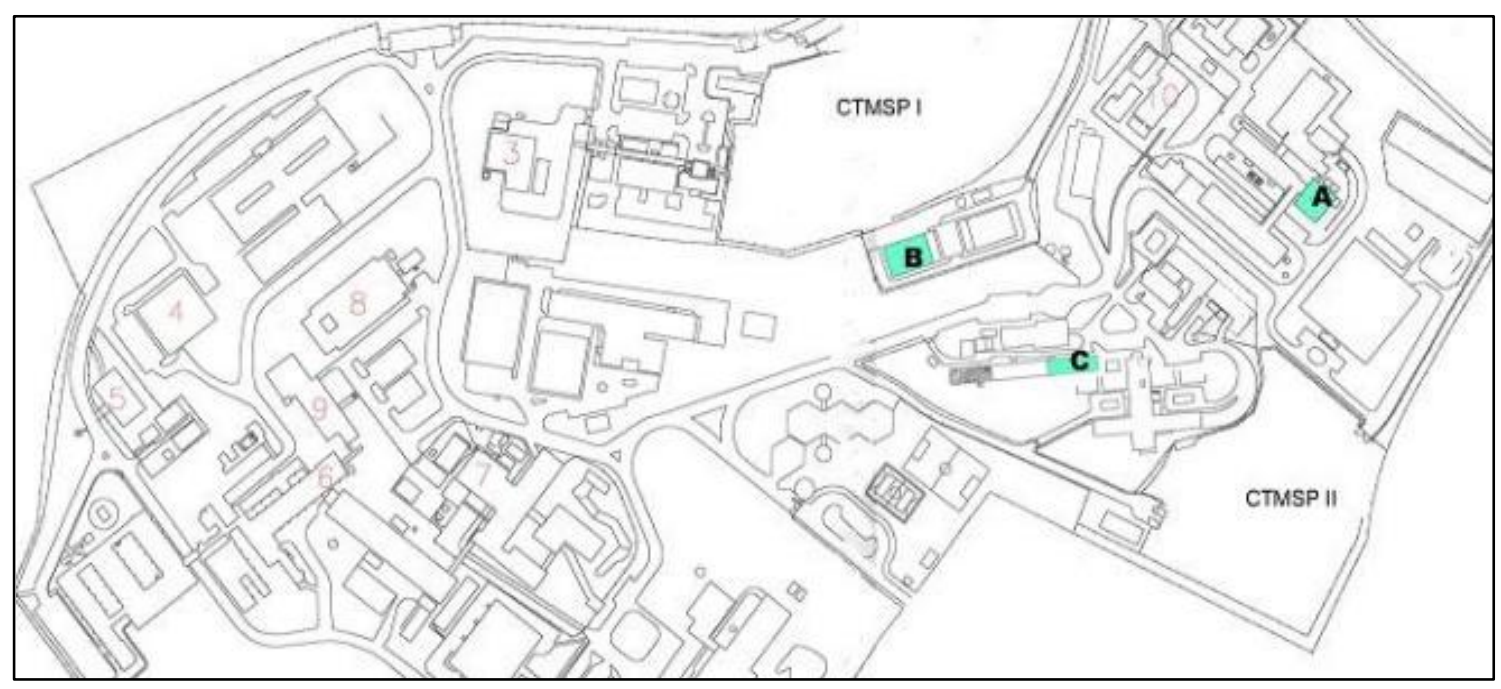

Fonte: Descrição das Atividades e Operações - Centro do Combustível Nuclear (2007). 
Tabela 2.1: Áreas do CCN e suas respectivas atividades.

Reconversão de $\mathrm{UF}_{6}$ $(\mathrm{RC})$
- Transferência do $\mathrm{UF}_{6}$,

- Produção de tetrafluoreto de urânio $\left(\mathrm{UF}_{4}\right)$ a partir da hidrólise do hexafluoreto de urânio $\left(\mathrm{UF}_{6}\right)$ enriquecido a $20 \%$ em peso de U-235
Processamento Químico

Recuperação de Urânio (RU)
- Recuperação do urânio contido em subprodutos rejeitados na linha de fabricação.
Tratamento de

Efluentes Industriais (TEI)
- Tratamento dos efluentes convencionais
- Produção de urânio metálico $\left(U^{\circ}\right)$ a partir do pó de $U_{4}$

- Produção da liga de siliceto de urânio $\left(\mathrm{U}_{3} \mathrm{Si}_{2}\right)$ a partir do urânio metálico

- Produção dos núcleos combustíveis a partir do pó de $\mathrm{U}_{3} \mathrm{Si}_{2}$ e alumínio

- Produção das placas combustíveis com os núcleos de $\mathrm{U}_{3} \mathrm{Si}_{2}-\mathrm{Al}$

- Montagem dos elementos combustíveis

e Montagem do EC (FPM)

Metrologia e Controle de Processo (MCP)

- Análise de Imagem

Fonte: Descrição das Atividades e Operações - Centro do Combustível Nuclear (2007).

\subsection{Processo de Produção do Combustível Nuclear}

$\mathrm{O} \mathrm{UF}_{6}$ com base em $\mathrm{U}_{3} \mathrm{Si}_{2}$ é utilizado como matéria prima para a produção do elemento combustível nuclear. $\mathrm{Na}$ fabricação de combustíveis nucleares, o processo é iniciado com o recebimento de hexafluoreto de urânio 
em cilindros tipo 5A e/ou 5B no enriquecimento especificado pelo Centro de Engenharia Nuclear (CEN) do IPEN/CNEN-SP (no máximo 19,75 $\pm 0,20 \%$ em peso de ${ }^{235} \mathrm{U}$ ) para a fabricação de combustíveis.

O recebimento do cilindro de $U_{6}$ é realizado pela área externa lateral do prédio, pertencente à Área CCR. O descarregamento é realizado com o acompanhamento do corpo técnico da proteção radiológica, que realiza monitorações para caracterização das condições dosimétricas, a fim de verificar se ocorreram alterações nos níveis de dose durante o transporte do cilindro e também orientando os técnicos na operação de descarregamento. Uma vez realizada a pesagem, o cilindro de $\mathrm{UF}_{6}$ é conduzido para a sala de salvaguardas, onde permanece armazenado até que seja iniciado 0 processamento do $\mathrm{UF}_{6}$. A massa bruta do cilindro é registrada, assim como os dados relativos ao cilindro [12].

Para seu processamento o cilindro de $U_{F_{6}}$ é pesado em uma balança e posteriormente acoplado ao sistema de transferência de $\mathrm{UF}_{6}$, composto de um forno de aquecimento resistivo, um sistema de vácuo e uma ampola colocada num frasco criogênico. Inicialmente verifica-se a existência de vazamento na linha efetuando vácuo em todo o sistema. $\mathrm{O}$ cilindro contendo o $\mathrm{UF}_{6}$ é inserido no forno tubular [12].

Face à alta reatividade química do hexafluoreto de urânio, principalmente frente à água, e a necessidade de se evitar o acúmulo de material nas tubulações da linha, põe-se em funcionamento a unidade de vácuo [12].

Esta unidade de vácuo é composta por uma bomba de vácuo de duplo estágio e de armadilhas criogênicas (traps) para evitar qualquer liberação de material via bomba de vácuo. Assim, a transferência é realizada num ambiente livre de contaminantes que possam afetar a pureza final do material coletado [12].

A quantidade de $\mathrm{UF}_{6}$ transferido do cilindro $5 \mathrm{~A}$ para a ampola tipo $1 \mathrm{~S}$ é de $3,0 \pm 0,3 \mathrm{~kg}$, de acordo com a massa segura calculada considerando a criticalidade.

As próximas etapas que envolvem o processo de produção do elemento 
combustível serão apresentadas de acordo com as atividades que envolve cada prédio. E também se tem um fluxograma do processo em forma de diagrama de blocos na Figura 2.2 destacando as respectivas etapas e os setores em que ocorrem.

Figura 2.2 Diagrama de blocos do processo de produção do EC.

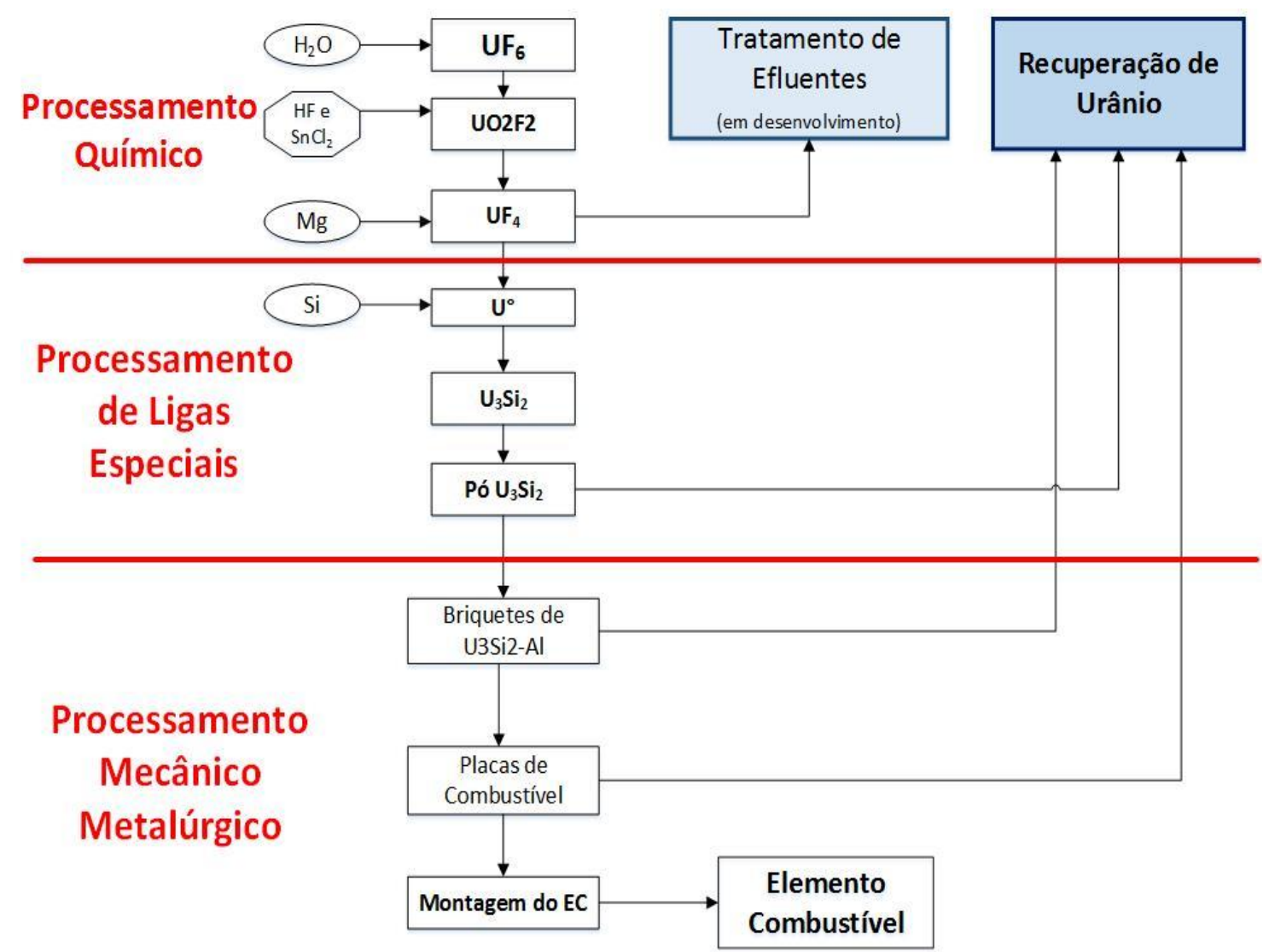

Fonte: Autora da dissertação

\subsubsection{Processamento Químico}

A ampola com $\mathrm{UF}_{6}$ obtida após a transferência é introduzida em uma autoclave a vapor e aquecida para sublimação do $\mathrm{UF}_{6}$, esse é transferido por diferença de pressão, para o reator de hidrólise, onde na presença de água destilada reage, obtendo-se uma solução de fluoreto de uranilo $\left(\mathrm{UO}_{2} \mathrm{~F}_{2}\right)$ [12].

A solução de $\mathrm{UO}_{2} \mathrm{~F}_{2}$ é bombeada para o reator de precipitação de $\mathrm{UF}_{4}$. $\mathrm{O}$ $\mathrm{U}^{+6}$ contido na solução de $\mathrm{UO}_{2} \mathrm{~F}_{2}$ é reduzido a $\mathrm{U}^{+4}$ utilizando como agente 
redutor cloreto de estanho II $\left(\mathrm{SnCl}_{2}\right)$, sendo o urânio precipitado na forma de $\mathrm{UF}_{4}$ mediante a adição de ácido fluorídrico (HF) à solução [12].

A suspensão obtida é transferida do reator de precipitação para o filtro horizontal a vácuo. $\mathrm{A}$ torta de $\mathrm{UF}_{4}$ é então lavada com água deionizada. $\mathrm{O}$ filtrado é recolhido em tanques de armazenamento e enviado ao Setor de Tratamento de Efluentes. A água de lavagem é utilizada na batelada posterior [12].

A massa contendo $\mathrm{UF}_{4}$ é inicialmente seca em estufa e posteriormente transferida para o forno para a retirada da água de cristalização. O produto é amostrado para caracterização química e física, caso seja solicitado [12].

As operações de transferência do pó de $U_{4} F_{4}$ são realizadas manualmente com o pó de $\mathrm{UF}_{4}$ armazenado adequadamente segundo as normas de proteção radiológicas. $\mathrm{O} \mathrm{UF}_{4}$ é transferido para o Setor de Redução e Fusão de Ligas [12].

O setor de Processamento Químico realiza três atividades, como apresentada na Tabela 3.1, das quais duas já foram citadas até o momento, pois estão no início do processo e a terceira atividade é resultante dos materiais não qualificados das próximas etapas do processo que serão encaminhados para a recuperação de urânio [12].

Esse setor realiza o tratamento e recuperação de refugos tais como: placas, briquetes e pós fora da especificação provenientes do processo de fabricação de combustível à base de $\mathrm{U}_{3} \mathrm{Si}_{2}-\mathrm{Al}$; escória da produção de urânio metálico; e refugos proveniente das análises de qualificação química do material combustível [12].

O tratamento e recuperação do urânio presente nas placas e briquetes do combustível à base de $\mathrm{U}_{3} \mathrm{Si}_{2}-\mathrm{Al}$ inicia-se com a dissolução do alumínio, obtendo-se, após a filtração, o $\cup_{3} \mathrm{Si}_{2}$ impuro. O material impuro é dissolvido com ácido nítrico, obtendo-se uma solução de nitrato de uranilo impuro. Esse nitrato é enviado ao sistema de purificação por extração com solvente, obtendo-se uma solução de nitrato de uranilo puro, que é transferido por bombeamento ao reator de precipitação de diuranto de amônia puro, e 
calcinado posteriormente a $\cup_{3}$. A seguir, faz-se reagir $\circ \cup_{3}$ com ácido fluorídrico na presença de cloreto de estanho II obtendo-se o tetrafluoreto de urânio. $\mathrm{OUF}_{4}$ é seco, desidratado e enviado para o Setor de Redução e Fusão de Ligas da Área de Ligas Especiais, onde ele retorna o processo para a produção de urânio metálico [12].

As utilidades necessárias para o funcionamento do setor são: água de refrigeração, ar comprimido e gases analíticos (argônio, nitrogênio, ar sintético, amônia) [12].

Os efluentes gerados no CCN são conduzidos ao Setor de Tratamento de Efluentes Industriais em tanques de armazenamento, sendo tratado o efluente de DUA por troca iônica. A bancada experimental de tratamento do efluente do $U F_{4}$ é composta por uma infraestrutura laboratorial destinada ao levantamento de dados sobre o processo, pois o tratamento do efluente ainda está em desenvolvimento [12].

Ressalta-se que no CCN não há geração de rejeitos radioativos que não contenham urânio, sendo o urânio o único radioisótopo processado. O Centro de Química e Meio Ambiente-CQMA do IPEN/CNEN-SP fornece o suporte às áreas produtivas quanto à caracterização química das matérias-primas e produtos e quanto ao desenvolvimento de procedimentos operacionais e otimização dos processos conduzidos no CCN. A quantidade de ensaios e análises varia em função das amostras submetidas e dos ensaios requeridos [12].

\subsubsection{Processamento de Ligas Especiais}

Para a obtenção de urânio metálico, o pó de $\mathrm{UF}_{4}$ é transferido para uma caixa de luvas (glovebox) de carregamento, onde é pesado, misturado com magnésio metálico e homogeneizado [12].

A carga de redução é colocada manualmente no cadinho de grafite que é, então, colocado na bomba de redução, a qual é inserida no interior do forno de redução, tipo poço, com o auxílio de uma talha [12].

O forno de redução é aquecido, e depois de decorrido o tempo necessário para a conclusão da reação de redução, obtém-se o urânio metálico. A bomba 
de redução é retirada do forno para então ser resfriada. Após a desmontagem da bomba de redução, a escória gerada é separada do lingote de urânio metálico, esse é limpo e seco, sendo então pesado e armazenado para posterior fusão com silício para a obtenção do siliceto de urânio. A escória contendo urânio é transferida para o Setor de Recuperação de Urânio [12].

Para a obtenção de siliceto de urânio, o urânio metálico é misturado com grânulos de silício, formando a carga para fusão, e inserida em um forno de indução equipado com um sistema de vácuo e controle de atmosfera [12].

A carga de fusão é preparada em uma capela de laboratório colocando o lingote de urânio num cadinho de zircônia o qual é colocado no centro da espira de indução. Após a colocação da carga no forno e fechamento do mesmo, faz-se a efetiva evacuação da câmara de fusão por meio de uma bomba de vácuo até que a pressão atingir o valor pré-determinado, o gás de argônio é então introduzido, estabelecendo-se uma atmosfera [12]

Quando a fusão é completada, o forno é desligado, resfriado e completamente preenchido com argônio até a pressão atmosférica, sendo aberto para a retirada do lingote. O lingote é pesado e é feita uma inspeção visual, sendo a qualificação desse produto realizada após sua cominuição, realizada em caixa de luvas [12].

O pó de $U_{3} \mathrm{Si}_{2}$ é armazenado em uma caixa de luvas com atmosfera de argônio. A caixa de luvas contém no seu interior o peneirador vibratório que efetua a separação das frações granulométricas. $O$ descarregamento do pó das peneiras é realizado manualmente. Os pós obtidos são pesados, recolhidos e armazenados em recipientes cilíndricos. O lote de siliceto de urânio é ajustado quanto à composição de finos e homogeneizado, sendo acondicionado sob atmosfera inerte e armazenado em recipiente anteriormente descrito, retirando nesta etapa amostras para qualificação [12].

\subsubsection{Processamento Mecânico-Metalúrgico}

Para a fabricação dos briquetes, o pó de siliceto de urânio e de alumínio são pesados e homogeneizados preparando uma carga por pesagem. As cargas pesadas e homogeneizadas são compactadas. Após a sua remoção da 
matriz, os briquetes gerados são examinados, retificados as eventuais rebarbas, pesados, medidos e identificados. Os briquetes dentro da especificação são embalados em papel alumínio e armazenados em dessecador no interior da caixa de luvas. Os briquetes rejeitados são enviados ao Setor de Recuperação de Urânio [12].

Os briquetes qualificados são desgaseificados em um forno térmico, embalados em papel alumínio e enviados ao Setor de Fabricação de Placas e Montagem do EC, onde são imediatamente acondicionados em um dessecador [12].

As placas combustíveis são fabricadas utilizando a tecnologia de moldurarevestimento. A laminação é feita em um conjunto composto pelo núcleo (briquete), uma placa de moldura em alumínio e duas de revestimento, todas de alumínio. O briquete é posicionado na cavidade da moldura e o conjunto montado é soldado em suas bordas. Para se proceder à etapa seguinte do processo, o conjunto soldado, devidamente identificado, é inserido no forno para aquecimento [12].

É apresentado na Figura 2.3 a montagem da placa combustível, que é um conjunto de briquete e moldura de alumínio envolvidas por duas placas de alumínio, o qual é soldado nas bordas para em seguida passar pelo processo de laminação. A laminação a quente é realizada em vários passes conforme programa estabelecido. Após a laminação a quente realiza-se o teste de bolhas (blister test) fazendo-se uso do mesmo forno utilizado para o processo de laminação a quente [12].

Após a retirada do forno, as placas combustíveis são enviadas ao Setor de Metrologia e Controle de Processo, onde são inspecionadas visualmente e realizado o registro de bolhas. As placas combustíveis que apresentarem bolhas são registradas como refugo na folha de registro da laminação a quente e transferidas para o Setor de Recuperação de Urânio [12]. 
Figura 2.3 Esquema de montagem da placa combustível.

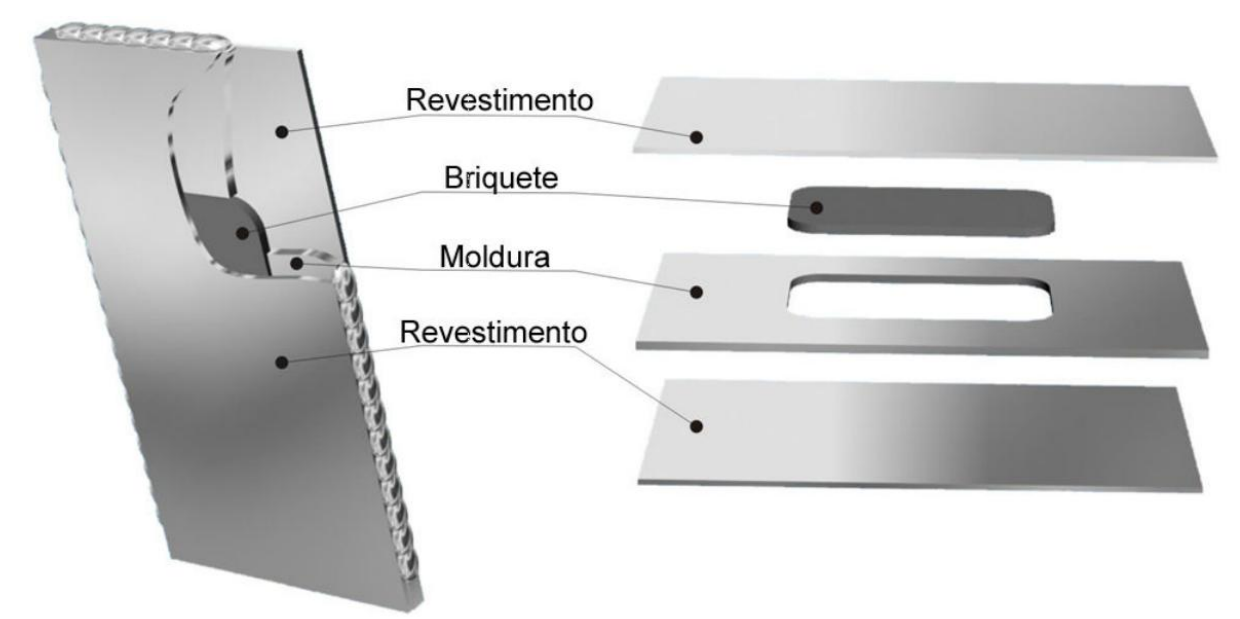

Fonte: MATTOS, L. A. T. (2014)

As placas qualificadas são laminadas a frio no mesmo laminador utilizado para a laminação a quente. Após a laminação a frio, as placas combustíveis são pré-cortadas visando facilitar o manuseio posterior nas etapas de aplainamento, radiografia, traçagem e corte final. Durante o processo de traçagem, as placas são identificadas por meio de um marcador com comando numérico [12].

As placas combustíveis identificadas são retificadas manualmente e encaminhadas ao Setor de Metrologia e Controle de Processo para análise dimensional. A seguir as placas combustíveis são desengraxadas quimicamente. Para cada lote (24 placas combustíveis), uma placa é retirada e verificada sua espessura inicial e final. As placas combustíveis qualificadas são embaladas individualmente em sacos plásticos selados. As placas são estocadas em estojos especiais fabricados até a montagem do elemento combustível [12].

Dois tipos de elementos combustíveis à base de $\mathrm{U}_{3} \mathrm{Si}_{2}$-Al são atualmente fabricados. O Elemento Combustível Padrão, constituído de dezoito placas combustíveis, dois suportes laterais (direito e esquerdo), um bocal, um pino de sustentação e oito parafusos. O Elemento Combustível de Controle é constituído de doze placas combustíveis, dois suportes laterais (direito e esquerdo), duas placas guia, um bocal, um cilindro do dash-pot ou amortecedor e 8 (oito) parafusos [12]. 
A montagem do elemento combustível é realizada no Setor de Fabricação de Placas e Montagem do EC. As placas são fixadas por cravamento [12].

O elemento combustível montado é caracterizado dimensionalmente em uma máquina tridimensional. O elemento combustível qualificado é limpo e inspecionado visualmente procurando-se detectar possíveis obstruções causadas por cavacos ou materiais estranhos resultantes da fixação do bocal e pino de sustentação. O elemento combustível é acondicionado em saco de polipropileno, selado e armazenado em caixa de madeira. $O$ elemento combustível é monitorado pelos técnicos da proteção radiológica, sendo preferencialmente transferido para o reator [12].

\subsection{Questão Ambiental}

A preocupação com os efeitos dos impactos ambientais, decorrentes da ação humana na natureza, passou a receber maior atenção partir da década de 1950 devido à queda da qualidade de vida em algumas regiões do planeta. Nessa época, surgiram movimentos ambientalistas, entidades governamentais sem fins lucrativos e agências governamentais focadas para a proteção ambiental [13].

Na década de 1970 um grupo de cientistas do Massachusetts Institute of Technology (MIT) que ajudava a organização Clube de Roma, alertou sobre os riscos do crescimento econômico baseado na exploração de recursos naturais não renováveis. O planeta não suportaria o crescimento populacional devido à pressão gerada sobre os recursos naturais e energéticos e o aumento da poluição, mesmo tendo em conta o avanço tecnológico [13].

Muitas das previsões citadas no relatório elaborado pelos cientistas do MIT não aconteceram, e outras permaneceram com um cenário possível. Mas, o documento foi importante para darmos mais atenção no impacto que a exploração dos recursos e a degradação do meio ambiente poderia causar [13].

Essa década ficou conhecida como a década da regulamentação e do controle ambiental. As nações começaram a organizar seus órgãos ambientais e estabelecer legislações, e poluir passou a ser considerado crime [13]. 
Na década seguinte, o Relatório de Brundtland propõe o desenvolvimento sustentável: aquele que atende as necessidades do presente sem comprometer a possibilidade de as gerações futuras atenderem as suas necessidades. Houve também, o surgimento de legislações mais específicas que visavam controlar a instalação de novas indústrias e estabelecer exigências para as existentes. $O$ foco era no controle da poluição no end pipe (final do tubo), em que se tratava o efluente, resíduo ou emissão. Na mesma época, a Constituição Brasileira de 1988 em seu artigo 225 expôs sua preocupação com o meio ambiente: "Todos têm direito ao meio ambiente ecologicamente equilibrado, bem de uso comum do povo e essencial à sadia qualidade de vida, impondo-se ao Poder Público e à coletividade o dever de defende-lo e preservá-lo para a presentes e futuras gerações" [14].

Inicialmente, a proteção ambiental era vista por um ângulo mais defensivo, estimulando apenas soluções corretivas que visavam atender a legislação. A partir da década de 1990 o foco passou a ser a otimização do processo produtivo e a redução do impacto ambiental. Os esforços para se utilizar tecnologias mais limpas e menos poluentes aumentaram, o que fez com que surgisse o conceito de ciclo de vida dos produtos, nos quais buscavam torná-los ecologicamente corretos desde a fase de concepção até o descarte ou reaproveitamento. Ocorreu também a introdução de novos conceitos, como: Certificação Ambiental, Atuação Responsável e Gestão Ambiental [14].

Com a introdução da gestão ambiental e a adoção dos códigos de conduta, as empresas adquirem uma nova postura na qual apresentam um maior cuidado com a imagem da organização em relação às questões ambientais. Posteriormente, surgem as normas britânicas BS 7750 e, em seguida, um sistema de normas ambientais em nível mundial (ISO 14000). Assim, a questão ambiental em nível empresarial transforma-se em uma possível solução para a imagem e credibilidade da organização em relação a sociedade por meio da qualidade e competitividade dos produtos [14].

Nos anos 2000, o Brasil foi aprovado o Estatuto das Cidades, que tem por objetivo promover a reforma urbana e o combate à especulação imobiliária; à ordenação do uso e ocupação do solo urbano; à gestão democrática da cidade [14]. 
No total, a evolução da preocupação com o meio ambiente teve três fases: a primeira fase da preocupação ambiental, na qual prevalecia um tratamento pontual das questões ambientais; a segunda fase que se caracteriza pela busca de uma nova relação entre o meio ambiente e desenvolvimento; a terceira fase é a fase atual, na qual busca-se pelo aprofundamento e implementação das disposições e recomendações dos estados nacionais, governos locais, empresas e outros agentes [13].

Assim, na fase atual da evolução, as empresas buscam implantar a gestão ambiental em suas práticas de uma forma mais proativa, como exemplo antecipando-se às exigências legais ou indo além do que a lei exige. $O$ efeito da produção é avaliado desde a seleção da matéria prima até o descarte dos resíduos pelo consumidor, passando pelo melhor aproveitamento dos insumos e resíduos lançados no ambiente. Essa atitude não traz resultados apenas ambientais como também reduz os desperdícios de recursos e concomitantemente diminui os custos [14].

O Sistema de Gestão Ambiental (SGA) é um conjunto de procedimentos que visa a ajudar a organização a entender, controlar e diminuir os impactos ambientais de suas atividades, produtos ou serviços. Esse sistema está baseado no cumprimento da legislação ambiental da organização [13].

O SGA também irá possibilitar às organizações uma melhor condição de gerenciamento para seus aspectos e impactos ambientais, além de interagir na mudança de atitudes e de cultura da organização. Poderá alavancar seus resultados financeiros, uma vez que atua na melhoria contínua de seus processos e serviços [13].

A série de normas ISO 14000 tem como objetivo a criação de um SGA que auxilie as organizações a cumprir os compromissos assumidos com 0 ambiente natural [15].

A ISO 14000 é uma forma de administrar o meio ambiente, definindo elementos de um SGA, auditoria de um SGA, avaliação de desempenho ambiental, rotulagem ambiental e análise de ciclo de vida [15].

A norma ISO 14000 é composta por 19 documentos principais, listados na 
Tabela 2.2 a seguir, a qual especifica o número da norma, sua atual situação (status) e o título que indica o assunto que a norma trata. As Normas ISO estão sempre sendo atualizadas e criadas, logo quando uma norma possui o status de publicada significa que está em vigor; quando a norma aparece com o status de documento de trabalho significa que está em fase de discussão; a norma que necessita apenas da aprovação final aparece com o status de final de projeto; quando está no estágio inicial de elaboração seu status é de documento de estudo e finalmente, quando está em estágio inicial de discussão o status será de anteprojeto [15].

Tabela 2.2 Normas ISO existentes e seus status. (continua)

\begin{tabular}{cll}
$\begin{array}{c}\text { Número de } \\
\text { série ISO }\end{array}$ & Status & \multicolumn{1}{c}{ Título } \\
\hline $\mathbf{1 4 0 0 1}$ & Publicada & $\begin{array}{l}\text { Sistemas de Gestão Ambiental - } \\
\text { Especificação e diretrizes para uso. }\end{array}$ \\
\hline $\mathbf{1 4 0 0 4}$ & Publicada & $\begin{array}{l}\text { Sistemas de Gestão Ambiental - Diretrizes } \\
\text { gerais sobre princípios, sistemas e técnicas } \\
\text { de apoio. }\end{array}$ \\
\hline $\mathbf{1 4 0 1 0}$ & Publicada & $\begin{array}{l}\text { Diretrizes para autoria ambiental - Princípios } \\
\text { gerais. }\end{array}$ \\
\hline $\mathbf{1 4 0 1 1}$ & Publicada & $\begin{array}{l}\text { Diretrizes para autoria ambiental - } \\
\text { Procedimentos de autoria - Auditoria de } \\
\text { sistemas de gestão ambiental. }\end{array}$ \\
\hline $\mathbf{1 4 0 1 5}$ & Publicada & $\begin{array}{l}\text { Diretrizes para autoria ambiental - critérios } \\
\text { de qualificação para auditores. }\end{array}$ \\
\hline
\end{tabular}

14020

Final de projeto Rótulos e atestados ambientais - princípios Norma Internacional gerais.

Rótulos e atestados ambientais - queixas autodeclaradas:

- Termos e definições (antiga 14021);

- Símbolos (antiga 14022);

- Teste e verificação (antiga 14023). 
Tabela 2.2 Normas ISO existentes e seus status.

(continuação)

\begin{tabular}{|c|c|c|}
\hline 14024 & $\begin{array}{l}\text { Projeto Norma } \\
\text { Internacional }\end{array}$ & $\begin{array}{l}\text { Rotulagens e atestados ambientais - } \\
\text { rotulagem ambiental tipo I. }\end{array}$ \\
\hline 14025 & $\begin{array}{l}\text { Documento de } \\
\text { trabalho }\end{array}$ & $\begin{array}{l}\text { Rotulagens e atestados ambientais - } \\
\text { rotulagem ambiental tipo III. }\end{array}$ \\
\hline 14031 & $\begin{array}{l}\text { Projeto Norma } \\
\text { Internacional }\end{array}$ & Avaliação de desempenho ambiental. \\
\hline 14032 & $\begin{array}{l}\text { Documento de } \\
\text { estudo }\end{array}$ & $\begin{array}{l}\text { Avaliação de desempenho ambiental - } \\
\text { estudos de caso. }\end{array}$ \\
\hline 14040 & Publicada & $\begin{array}{l}\text { Análise de ciclo de vida - princípios e } \\
\text { diretrizes. }\end{array}$ \\
\hline 14041 & $\begin{array}{l}\text { Final de projeto } \\
\text { Norma Internacional }\end{array}$ & $\begin{array}{l}\text { Análise de ciclo de vida - definição de } \\
\text { escopo e análise do inventário. }\end{array}$ \\
\hline 14042 & Anteprojeto & $\begin{array}{l}\text { Análise de ciclo de vida - avaliação de } \\
\text { impacto. }\end{array}$ \\
\hline 14043 & Anteprojeto & Análise de ciclo de vida - interpretação. \\
\hline 14050 & $\begin{array}{l}\text { Final de projeto } \\
\text { Norma Internacional }\end{array}$ & Vocabulário de Gestão Ambiental \\
\hline Guia 64 & Publicada & $\begin{array}{l}\text { Guia para a inclusão de aspectos ambientais } \\
\text { em normas sobre produtos. }\end{array}$ \\
\hline 14061 & Publicada & $\begin{array}{l}\text { Guia para orientar organizações florestais no } \\
\text { uso das normas ISO } 14001 \text { e } 14004 \text {. }\end{array}$ \\
\hline
\end{tabular}

Fonte: SPAZZANI, M. L., SILVA, P.G. F. (2012).

Os principais pontos de vantagem da adoção da ISO 14000 podem ser:

- Acesso de mercado - algumas empresas para negociarem com outras podem exigir essa norma;

- Incentivos reguladores - empresas que possuem um SGA podem estar sujeitas às inspeções menos frequentes, atenuações de multas, menos rigor na exigência de relatórios, etc.;

- Redução de responsabilidade e risco - um SGA eficiente identifica e administra melhor os riscos e a responsabilidade ambiental; 
- Acesso a capital de baixo custo - créditos com prazos mais longos, tempo de resposta mais rápido ao crédito, etc.;

- Melhoria na eficiência do processo - abordagem sistemática para identificar os aspectos e impactos ambientais leva a uma produção mais eficiente;

- Redução de custos / aumento de receita - maior sistematização diminui os custos de produção, aumentando a receita e a lucratividade;

- Relações com os clientes - com a maior influência dos consumidores sobre as questões ambientais, o produto da empresa tende a ser mais bem aceito no mercado [15].

Concluindo, a implementação da ISO 14000, mesmo não sendo obrigatória, é um instrumento muito importante relacionado à conservação ambiental. É uma forma de empreendimentos utilizarem os recursos naturais de forma racional, colaborando para o desenvolvimento sustentável e uma melhora da qualidade ambiental, que se reflete na qualidade de vida da população. E ainda agrega um maior valor aos produtos [15].

\subsection{Legislação de Interesse}

O Brasil através de novas legislações vem buscando proteger o meio ambiente da poluição industrial reconhecendo a necessidade de as organizações permanecerem economicamente viáveis [16].

A Constituição Federal Brasileira foi promulgada em 5 de outubro de 1988, contendo pela primeira vez um capítulo sobre meio ambiente e vários outros artigos afins. Em seu artigo 225, parágrafo $3^{\circ}$, estabelece que: "As condutas e atividades consideradas lesivas ao meio ambiente sujeitarão os infratores, pessoas físicas ou jurídicas, as sanções penais e administrativas, independentemente da obrigação de reparar os danos causados" [16].

No Brasil, os fatos marcantes na evolução das regulamentações foram: a aprovação da Lei 6.938 da Política Nacional de Meio Ambiente, em 31/08/81 [14]; e em 1986 o Conselho Nacional do Meio Ambiente (CONAMA) aprova a Resolução no 001/86 [18]. 
A Lei da Política Nacional do Meio Ambiente foi regulamentada inicialmente pelo Decreto 8.8351 de $01 / 06 / 83$, posteriormente revogada pelo Decreto 99.274 de 06/06/90, que o substituiu. Essa lei define como poluidor "a pessoa física ou jurídica, de direito público ou privado, responsável, direta ou indiretamente, por atividade causadora de degradação ambiental" e recursos ambientais como "a atmosfera, as águas interiores, superficiais e subterrâneas, os estuários, o mar territorial, o solo, o subsolo e os elementos da biosfera" [17].

A Resolução $n^{\circ}$ 001/86 estabelece que as responsabilidades, os critérios básicos e as diretrizes gerais para o uso e implementação da Avaliação de Impacto Ambiental (AIA) como um dos instrumentos da Política Nacional do Meio Ambiente [18].

Em relação à legislação relativa à área nuclear tem-se a norma CNENNE-1.04 sobre Licenciamento de Instalações Nucleares que tem como objetivo regular o processo de licenciamento de instalações nucleares [7]. E a norma CNEN-NE-3.01 que trata das Diretrizes Básicas de Radioproteção e tem como objetivo principal estabelecer as Diretrizes Básicas de Radioproteção, abrangendo os princípios, limites, obrigações e controles básicos para a proteção do homem e de seu meio ambiente contra possíveis efeitos causados pela radiação ionizante [19].

A Norma CNEN-NE-3.01 se aplica às pessoas físicas e jurídicas envolvidas na produção, uso, posse, armazenamento, processamento, transporte ou deposição de fontes de radiação, define o que é uma Instalação Radioativa e uma Instalação Nuclear e cita que as doses especificadas na Norma não se aplicam às doses resultantes de exposições médicas, naturais ou de emergência [20].

Para o presente trabalho foram consideradas a Resolução $n^{\circ} 357$, de 17 de março de 2005, e a Resolução do $n^{\circ}$ 430, de 13 de maio de 2011 do Conselho Nacional do Meio Ambiente - CONAMA [21,22].

A primeira resolução trata-se da classificação dos corpos de água e diretrizes ambientais para o seu enquadramento, além de estabelecer as condições e padrões de lançamentos de efluentes, e fornecer outras 
providências [21]. Já, a Resolução $n^{\circ} 430$ dispõe sobre condições, parâmetros, padrões e diretrizes para gestão do lançamento de efluentes em corpos de água receptores, alterando parcialmente e completando a Resolução n 357 , de 17 março de 2005 [22].

De acordo com as seguintes resoluções as condições de descarte de efluentes que se aplicam a esse trabalho são:

a) $\mathrm{pH}$ entre 5 a 9;

b) Temperatura inferior a $40^{\circ} \mathrm{C}$, sendo que a variação de temperatura do corpo receptor não deverá exceder a $3^{\circ} \mathrm{C}$ no limite da zona de mistura;

c) Concentração de Estanho total no valor máximo de 4,0 $\mathrm{mg} \mathrm{L}^{-1}$;

d) Concentração de Fluoreto total no valor máximo de 10,0 mg L-1;

e) Concentração de Urânio total no valor máximo de $0,02 \mathrm{mg} \mathrm{L}^{-1}$.

Um ponto importante a se destacar é saber diferenciar resíduo, rejeito e efluente. Resíduo é qualquer material que sobra após uma ação ou processo produtivo de extração de recursos naturais, transformação, fabricação ou consumo de produtos e serviços, podendo ser sólido, líquido ou gasoso. Os resíduos quando não tratados corretamente são descartados e acumulados no meio ambiente, causando poluição e desperdício da matéria usada [23].

Rejeito de acordo com a definição da Lei 12.305 de 2010 (Política Nacional de Resíduos Sólidos), são os resíduos sólidos que, depois de esgotadas todas as possibilidades de tratamento e recuperação por processos tecnológicos disponíveis e economicamente viáveis, não apresentem outra possibilidade que não a disposição final adequada. O rejeito pode ainda ser radioativo, ou seja, qualquer material resultante de atividades humanas, que contenha radionuclídeos em quantidades superiores aos limites de isenção, estabelecidos pela $\mathrm{CNEN}$, para o qual a reutilização é imprópria ou não prevista [24].

Efluentes são os resíduos provenientes das indústrias, dos esgotos e das redes pluviais, que são lançados no meio ambiente, na forma de líquidos ou de 
gases. A palavra efluente significa aquele que flui. É qualquer líquido ou gás gerado nas diversas atividades humanas e que são descartados na natureza.

\subsection{Impactos Ambientais que o $\mathrm{CCN}$ pode causar}

As informações que serão apresentadas nesse tópico são resultados obtidos a partir do estudo realizado pelo MATTOS, L. A. T. (2014) no qual o autor identifica e avalia os aspectos e impactos ambientais no CCN.

Aspecto ambiental é definido como elemento das atividades, produtos e serviços de uma organização. $O$ aspecto pode estar relacionado a uma máquina ou equipamento, assim como, a uma atividade executada por ela ou por alguém que produza ou apresente a possibilidade de produzir algum efeito sobre o meio ambiente [13].

Já impacto ambiental é qualquer mudança no meio ambiente, tanto positiva quanto negativa, total ou parcial, resultados das atividades, produto ou serviços da organização [13].

MATTOS, L. A. T. (2014) utilizou a técnica Failure Mode and Effect Analysis (FMEA) que consiste em identificar, de forma exaustiva e sistemática, os diversos modos de falha que geram os danos ambientais respectivos, procurando definir sua natureza e seu grau de significância relativa quanto ao dano potencial para o meio ambiente, que em uma última análise servirá como informação para tomada de decisões gerenciais a respeito de ações de prevenção e/ou redução de impactos ambientais significativos [12].

Para a utilização do método identificou-se os aspectos e impactos ambientais possíveis nos processos operacionais do $\mathrm{CCN}$ e aplicando critérios de significância, índices de severidade, de ocorrência e de detecção calculou um Índice de Risco Ambiental (IRA) para cada impacto ambiental [12]

Para calcular o IRA foi utilizado a seguinte equação:

$$
\operatorname{IRA}=(S * O * A * D)+L
$$

onde,

$S$ = índice de severidade; 
$O$ = índice de ocorrência;

A = índice de abrangência;

$\mathrm{D}=$ índice de detecção;

$L=0$, se não houver uma legislação ambiental aplicável. Caso contrário, $L=1$.

Se, $\quad I R A \geq 9$, então o aspecto ambiental é considerado significativo. Nesse caso, é obrigatória a implementação de controle operacional. Cabe ressaltar que, mesmo que determinado aspecto seja considerado como não significativo, há a necessidade de implantação de algum tipo de controle. O que pode variar é o nível de controle associado a cada aspecto ambiental [12].

O critério de severidade indica a magnitude do impacto ambiental estabelecida com base nas consequências para o meio ambiente, sendo as consequências estimadas em função de variáveis, tais como: volume/massa e classe de resíduos; características físico-químicas e radiológicas de efluentes; nível de controle necessário; nível de comprometimento de recursos naturais renováveis; reversibilidade; repercussão pública. A severidade do impacto ambiental pode também ser medida em função de aspectos relacionados aos elementos do SGA, como por exemplo: atendimento de requisitos legais; política ambiental; objetivos e metas ambientais [12].

O critério de ocorrência indica o número de vezes que o impacto ambiental pode se manifestar dentro de um determinado período de tempo, durante a vida útil da instalação nuclear ou radiativa, em condições normais de operação [12].

A abrangência representa a área de influência do impacto ambiental em termos de seu alcance espacial. E a detecção mostra o nível de percepção medido de acordo com a maior ou menor possibilidade de identificação do evento. O meio de detecção pode envolver ações automáticas (instrumentação on-line), inspeções periódicas ou atuação do operador [12].

Os critérios de significância de severidade, ocorrência e detecção possuem três níveis: baixo, médio e alto. $O$ critério de abrangência também possui três níveis, mas esses se limitam à local, interno e externo. Para cada nível está associado um índice, esse índice é o valor utilizado para calcular o 
IRA. Nas Tabelas 2.3 a 2.6 são apresentados os níveis de severidade, ocorrência, abrangência e detecção e seus respectivos índices.

Tabela 2.3 Índice de severidade de impactos ambientais.

\begin{tabular}{|c|c|c|}
\hline SEVERIDADE & CRITÉRIO & ÍNDICE \\
\hline Baixa & $\begin{array}{l}\text { Aspecto ambiental, que em função da rotina } \\
\text { operacional da instalação, está relacionado ao } \\
\text { impacto de magnitude desprezível, totalmente } \\
\text { reversível com ações imediatas e locais, envolvendo } \\
\text { substâncias não radioativas, inertes e biodegradáveis. }\end{array}$ & 1 \\
\hline Média & $\begin{array}{l}\text { Aspecto ambiental, que em função da rotina } \\
\text { operacional da instalação, possui magnitude média, } \\
\text { com degradação ambiental reversível com ações } \\
\text { imediatas envolvendo substâncias radioativas, não } \\
\text { inertes e não biodegradáveis. }\end{array}$ & 2 \\
\hline Alta & $\begin{array}{l}\text { Aspecto ambiental, que em função da rotina } \\
\text { operacional, possui magnitude alta, com degradação } \\
\text { ambiental, requerendo ações de remediação, } \\
\text { envolvendo substâncias radioativas e/ou perigosas. }\end{array}$ & 3 \\
\hline
\end{tabular}

Fonte: MATTOS, L. A. T. (2014).

Tabela 2.4 Índice de ocorrência de impactos ambientais.

\begin{tabular}{|c|c|c|}
\hline \multicolumn{2}{|l|}{ OCORRÊNCIA } & \multirow{2}{*}{ ÍNDICE } \\
\hline Baixa & $\begin{array}{l}\text { Aspecto ambiental, que em função da rotina } \\
\text { operacional da instalação, é identificado uma vez por } \\
\text { mês ou mais. }\end{array}$ & \\
\hline Média & $\begin{array}{l}\text { Aspecto ambiental, que em função da rotina } \\
\text { operacional da instalação, é identificado uma vez por } \\
\text { semana ou mais. }\end{array}$ & 2 \\
\hline Alta & $\begin{array}{l}\text { Aspecto ambiental, que em função da rotina } \\
\text { operacional da instalação, é identificado } \\
\text { continuamente. Inerente à realização da atividade. }\end{array}$ & 3 \\
\hline \multicolumn{3}{|c|}{ Fonte: MATTOS, L. A. T. (2014). } \\
\hline \multicolumn{3}{|c|}{ Tabela 2.5 Índice de detecção de impactos ambientais. } \\
\hline DETECÇÃO & CRITÉRIO & ÍNDICE \\
\hline Alto & $\begin{array}{l}\text { Aspecto ambiental relacionado a uma situação, cuja } \\
\text { falha tem detecção garantida, eliminando qualquer } \\
\text { possibilidade de degradação ambiental. A garantia de } \\
\text { detecção é dada por ações automáticas e por ação do } \\
\text { operador (redundância). }\end{array}$ & 1 \\
\hline
\end{tabular}




\begin{tabular}{clll}
\hline & $\begin{array}{l}\text { Aspecto ambiental relacionado a uma situação } \\
\text { operacional, cuja falha tem detecção garantida, mas } \\
\text { depende somente de um tipo de ação para eliminar } \\
\text { qualquer possibilidade de degradação ambiental (sem } \\
\text { redundância). }\end{array}$ & 2 \\
\hline Baixo & $\begin{array}{l}\text { Aspecto ambiental relacionado a uma situação } \\
\text { operacional, cuja falha não tem detecção garantida, } \\
\text { havendo possibilidade de degradação ambiental. }\end{array}$ & 3 \\
\hline
\end{tabular}

Fonte: MATTOS, L. A. T. (2014).

Tabela 2.6 Índice de abrangência de impactos ambientais.

\begin{tabular}{|c|c|c|}
\hline ABRANGÊNCIA & CRITÉRIO & ÍNDICE \\
\hline Local & $\begin{array}{l}\text { Aspecto ambiental, que em função da rotina } \\
\text { operacional da instalação, está restrito a uma } \\
\text { determinada área ou setor. Nesse caso, considera- } \\
\text { se a existência de algum tipo de barreira de } \\
\text { contenção, que restringe a abrangência do evento. }\end{array}$ & 1 \\
\hline Interna & $\begin{array}{l}\text { Aspecto ambiental, que em função da rotina } \\
\text { operacional da instalação, não se restringe aos } \\
\text { limites físicos (prédios) da instalação. }\end{array}$ & 2 \\
\hline Externa & $\begin{array}{l}\text { Aspecto ambiental, que em função da rotina } \\
\text { operacional da instalação, não se restringe aos } \\
\text { limites internos da instalação. }\end{array}$ & 3 \\
\hline
\end{tabular}

Fonte: MATTOS, L. A. T. (2014).

O critério $L$ pode ser denominado de critério adicional, esse refere-se ao aspecto ambiental relacionado às exigências de atendimento de requisitos legais formalizados por meio de condicionantes de Licenças Ambientais; Termo de Compromisso de Ajustamento de Conduta e Notificações/Infrações de órgãos ambientais regulamentadoras [12].

Os resultados das avaliações de significância foram realizados para os seguintes processos: Químico: $\mathrm{UF}_{6}$, Ligas Especiais, Mecânico-Metalúrgico, Químico: Recuperação de Urânio, Administrativo e estão expressos nas Tabelas 2.7 a 2.11 
Tabela 2.7 Planilha de identificação de aspectos e impactos ambientais Processo Químico: UF 6 .

\begin{tabular}{|c|c|c|c|c|c|c|c|c|c|c|c|c|c|c|c|c|c|c|c|c|c|c|}
\hline \multirow{3}{*}{ ipen } & \multirow{3}{*}{\multicolumn{4}{|c|}{ PLANILHA D }} & \multirow{3}{*}{\multicolumn{2}{|c|}{ E IDE }} & \multirow{3}{*}{\multicolumn{2}{|c|}{ NTIFIC }} & \multirow{3}{*}{\multicolumn{11}{|c|}{$\begin{array}{l}\text { AÇÃO DE ASPECTOS E IMPACTOS AMBIENTAIS } \\
\text { CCN/IPEN/CNEN-SP }\end{array}$}} & \\
\hline & & & & & & & & & & & & & & & & & & & & \multicolumn{3}{|c|}{$\begin{array}{l}\text { DATA: 05/03/2013 } \\
\text { RESPONSÁVEL: João Neto }\end{array}$} \\
\hline & & & & & & & & & & & & & & & & & & & & \multicolumn{3}{|c|}{ REVISÃO: 01} \\
\hline \multicolumn{23}{|c|}{$\begin{array}{l}\text { PROCESSO: PRODUÇAO /QUUIMICO:UF } \\
\text { FUNCCAO: Realizar as atividades obtençäo de UF } F_{4} \text { em pó a partir de UF } F_{6} \text { gasoso enriquecido em até } 20 \% \text { de }{ }^{2 \pi} \mathrm{U} \\
\text { UNIDADE(S): Laboratório de Transferéncia de UF }\end{array}$} \\
\hline \multirow{3}{*}{\multicolumn{2}{|c|}{$\begin{array}{l}\text { ASPECTOS } \\
\text { AMBIENTAIS }\end{array}$}} & \multicolumn{5}{|c|}{ ATIVIDADES } & \multicolumn{5}{|c|}{ IMPACTOS } & \multicolumn{6}{|c|}{ SIGNIFICÂNCIA } & \multicolumn{5}{|c|}{ PLANO DE GESTÃO AMBIENTAL } \\
\hline & & \multirow[b]{2}{*}{ 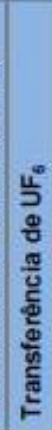 } & \multirow[b]{2}{*}{ 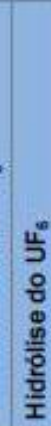 } & & \multirow[b]{2}{*}{ 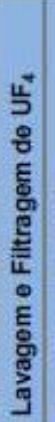 } & \multirow[b]{2}{*}{ 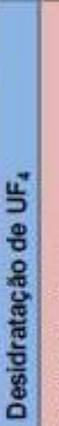 } & \multirow[b]{2}{*}{ : } & \multirow{2}{*}{\multicolumn{2}{|c|}{ 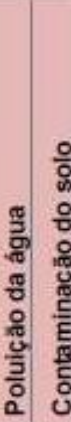 }} & & \multirow[b]{2}{*}{ 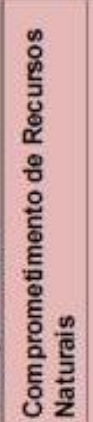 } & \multirow[b]{2}{*}{ 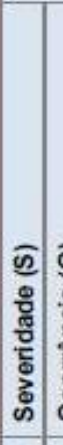 } & & \multirow[b]{2}{*}{ 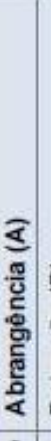 } & & & & & & & Requis & ito Legal \\
\hline & & & & 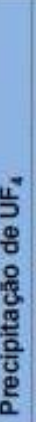 & & & & & & 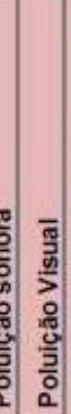 & & & 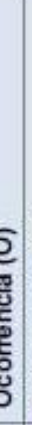 & & ఫ్ & 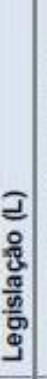 & 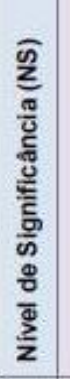 & 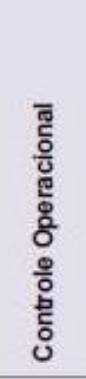 & 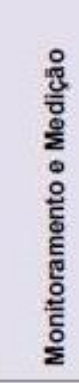 & 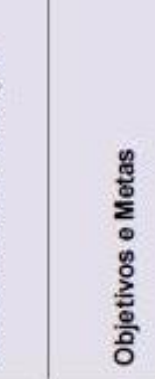 & \begin{tabular}{l|l}
$\mathbf{S}$ & $\mathrm{N}$
\end{tabular} & Código ${ }^{\top}$ \\
\hline Vazamento de UFG & $\mathrm{x}$ & $\mathrm{x}$ & $\mathrm{x}$ & & & & $x$ & $\mathrm{x}$ & $x$ & & & 3 & 2 & 2 & 1 & 1 & 13 & & & & & \\
\hline $\begin{array}{l}\text { Vazamento } \\
\text { Veiculo de }\end{array}$ & $\mathrm{x}$ & & & & & & & $\mathbf{x}$ & $x$ & & & 1 & 1 & 1 & 2 & 1 & 3 & & & $\begin{array}{l}\text { célula } \\
\text { sponde a }\end{array}$ & & $\begin{array}{l}\text { ula } \\
\text { nde a }\end{array}$ \\
\hline $\begin{array}{l}\text { Descarte de EPP's } \\
\text { usados }\end{array}$ & $x$ & $x$ & $\mathrm{x}$ & $x$ & $\mathrm{x}$ & $\mathbf{x}$ & & $\boldsymbol{x}$ & $x$ & & & 3 & 2 & 1 & 1 & 1 & 7 & & & & & ò̀ \\
\hline Incéndio & $x$ & $\mathrm{x}$ & $x$ & $x$ & $x$ & $x$ & $x$ & $x$ & $x$ & & $x$ & 3 & 1 & 3 & 1 & 1 & 10 & & & $\begin{array}{l}\text { ấ dos } \\
\text { imentos }\end{array}$ & & da \\
\hline Consumo de $\mathbf{R}$. Hidricos & & $x$ & & & & & & & & & $x$ & 2 & 1 & 3 & 1 & & 6 & & & & & \\
\hline Consumo de E. Elétrica & $x$ & $x$ & $x$ & $x$ & $x$ & & & & & & $x$ & 2 & 1 & 3 & 1 & - & 6 & & & & & para \\
\hline $\begin{array}{l}\text { Descarte de Residuos de } \\
\text { Limpeza }\end{array}$ & & $\mathrm{x}$ & & & & & & $\mathrm{x}$ & $\mathrm{x}$ & & & 2 & 2 & 1 & 1 & 1 & 5 & & & $\begin{array}{l}\text { lato } \\
\text { pecto }\end{array}$ & & \\
\hline $\begin{array}{l}\text { Descarte de Filtros do } \\
\text { Sistema de Vácuo }\end{array}$ & x & & & & & & & $x$ & $\mathrm{x}$ & & & 3 & 1 & 2 & 1 & 1 & 7 & & & & & \\
\hline Descarte & & $\mathrm{x}$ & & & & & & $x$ & $x$ & & & 3 & 2 & 2 & 1 & 1 & 13 & & & & 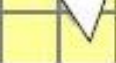 & \\
\hline $\begin{array}{l}\text { Descarte de soluçōes ol } \\
\mathrm{UF}_{4}\end{array}$ & & & & & $\mathrm{x}$ & & & $x$ & $x$ & & & 3 & 3 & 2 & 1 & 1 & 19 & & & & & \\
\hline
\end{tabular}

Fonte: MATTOS, L. A. T. (2014). 
Tabela 2.8 Planilha de identificação de aspectos e impactos ambientais Processo Ligas Especiais.

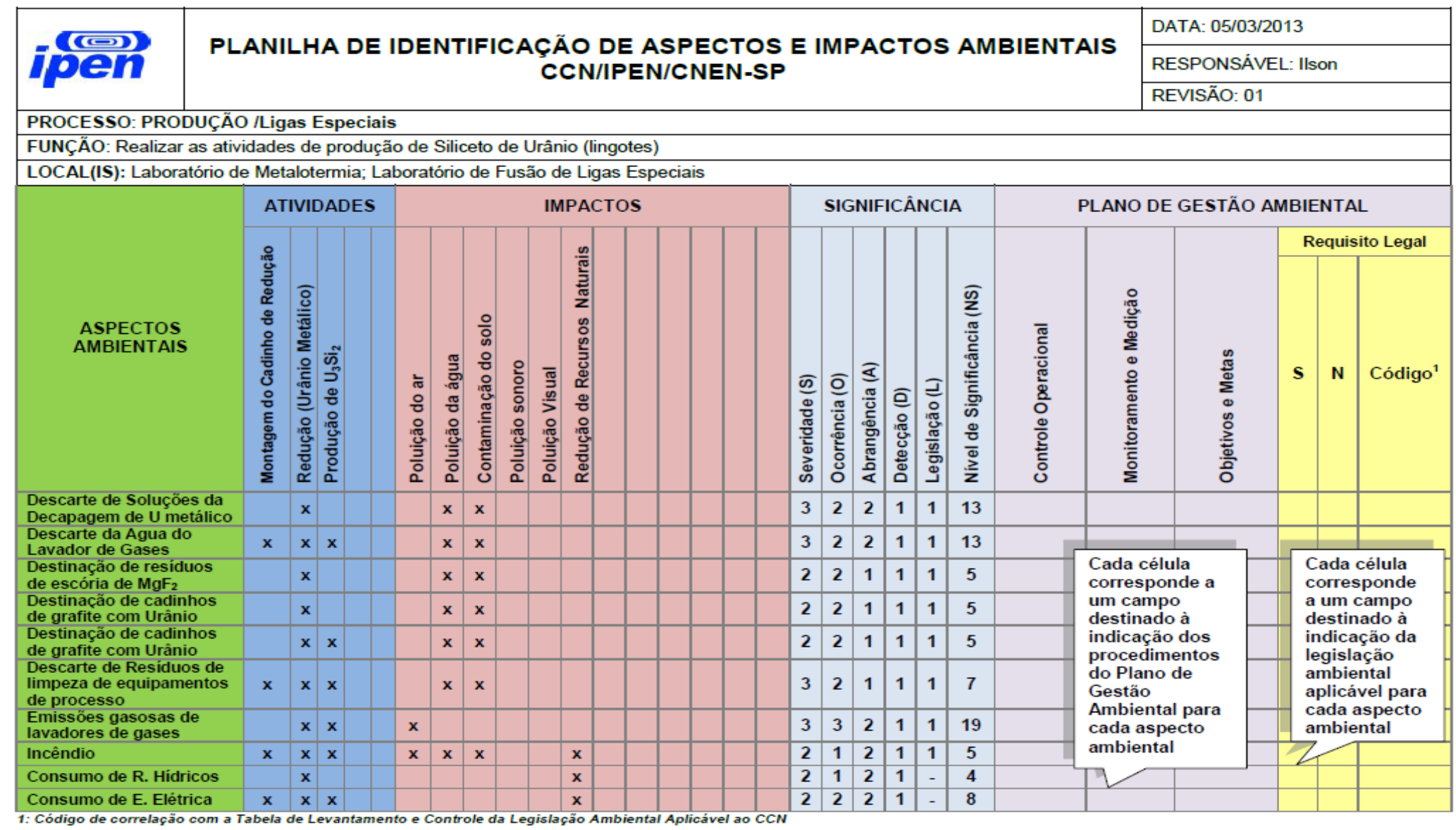

Fonte: MATTOS, L. A. T. (2014). 
Tabela 2.9 Planilha de identificação de aspectos e impactos ambientais Processo Mecânico-Metalúrgico.

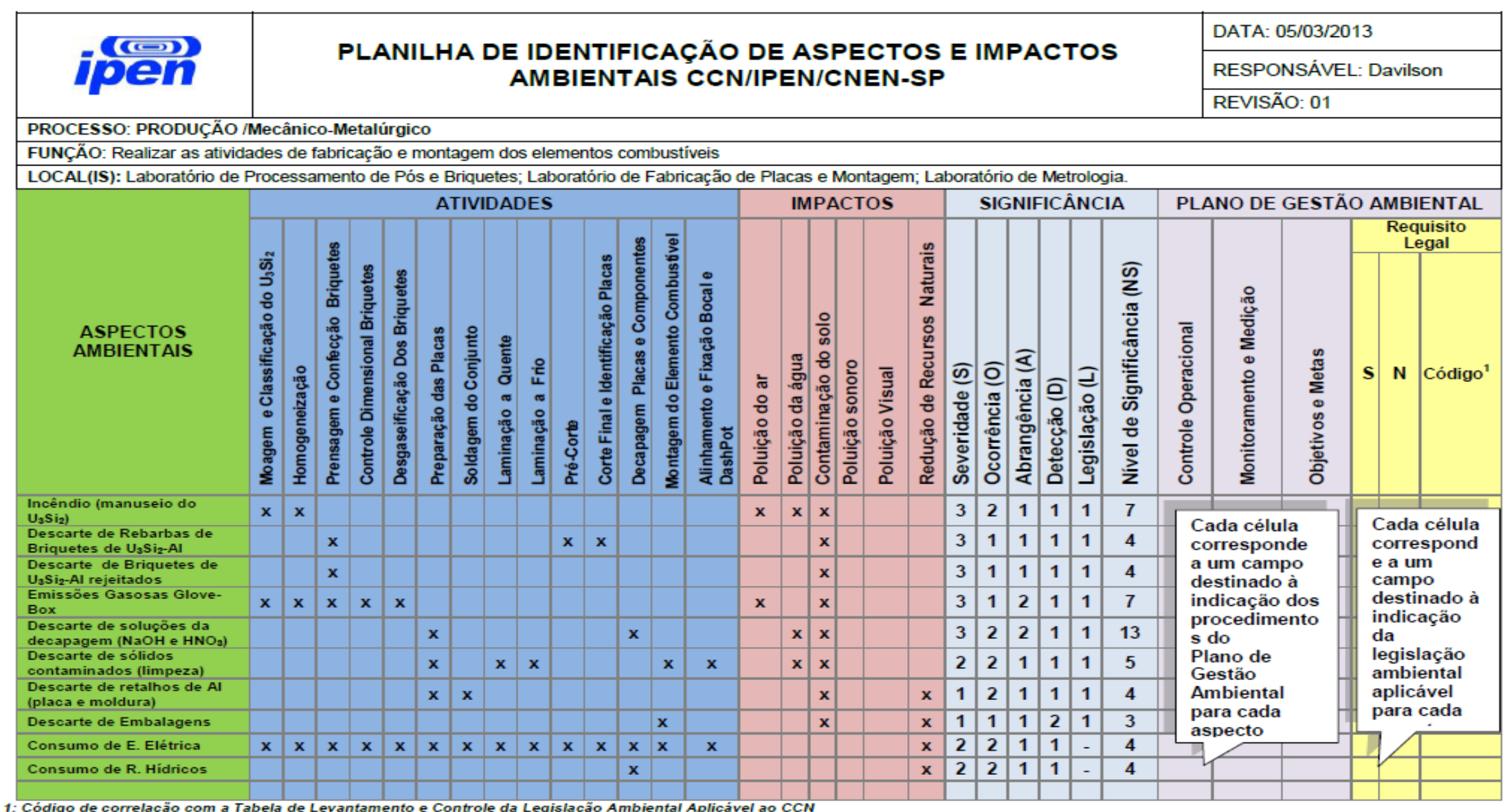

Fonte: MATTOS, L. A. T. (2014). 
Tabela 2.10 Planilha de identificação de aspectos e impactos ambientais Processo Químico: Recuperação de Urânio.

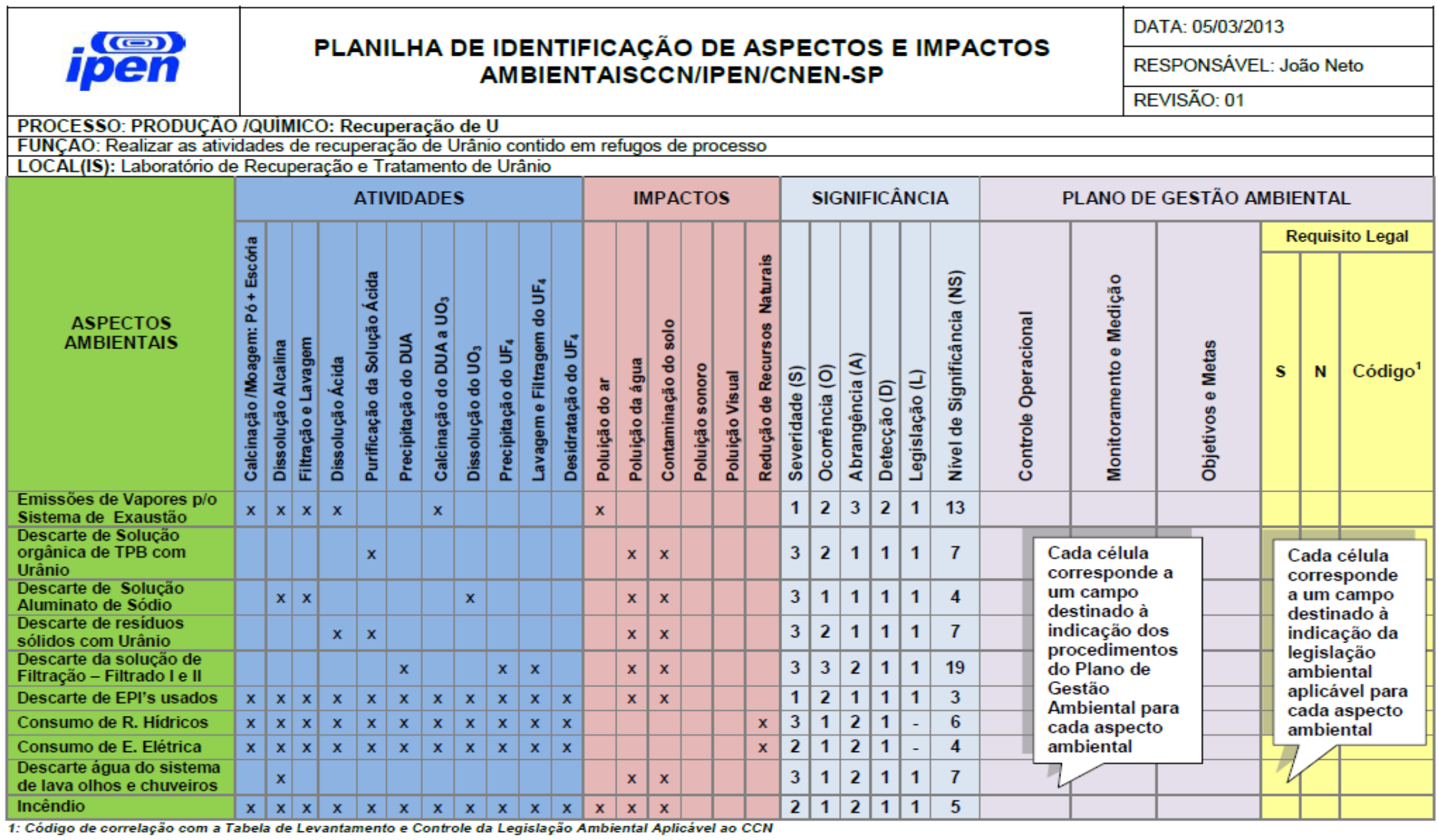

Fonte: MATTOS, L. A. T. (2014). 
Tabela 2.11 Planilha de identificação de aspectos e impactos ambientais Processo Administrativo.

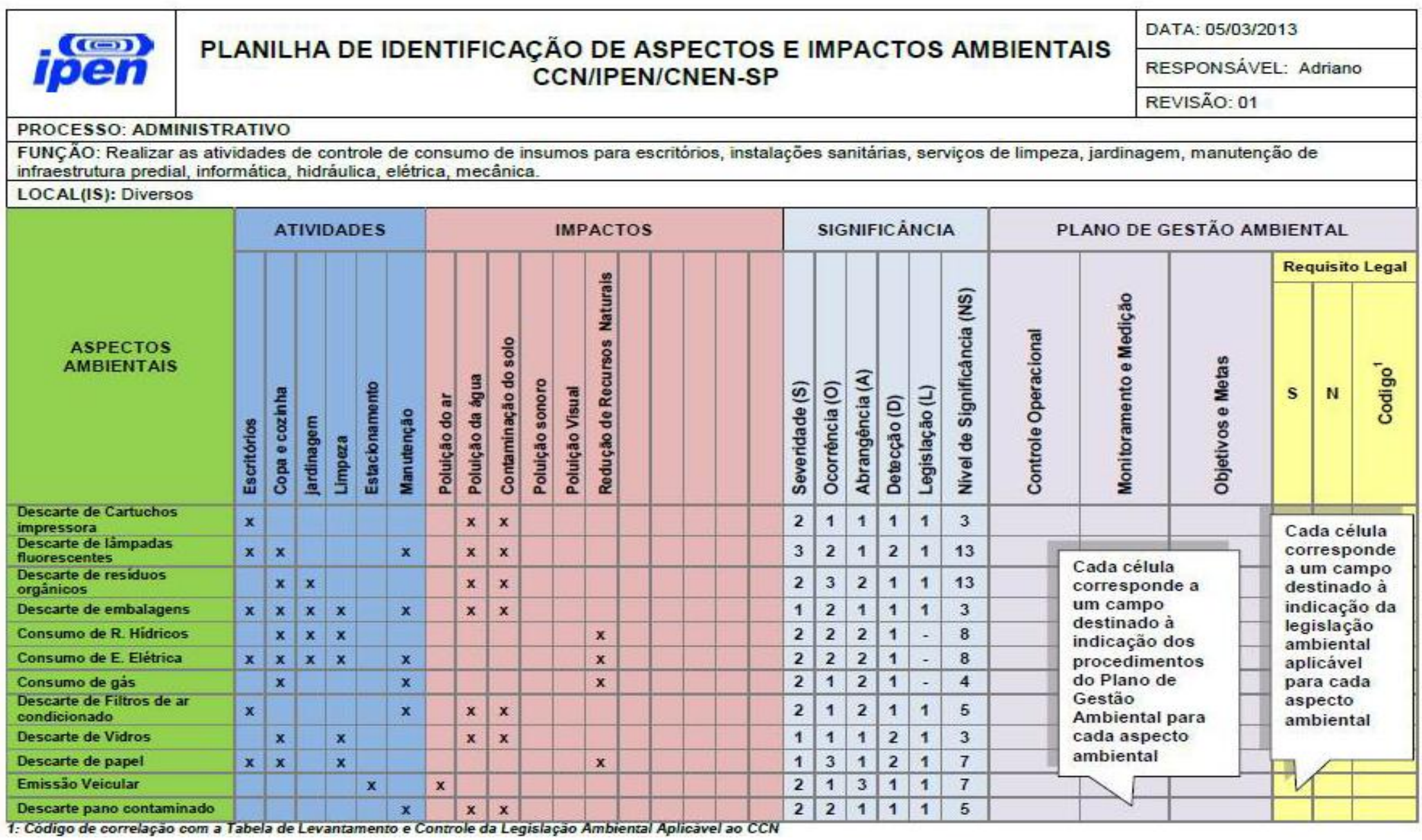

Fonte: MATTOS, L. A. T. (2014). 
Com os valores apresentados é possível detectar os aspectos ambientais que possuem maior chance de causar impactos ambientais [12]. São eles:

1. Processo Químico UF6:

a. Vazamento de $\mathrm{UF}_{6}$;

b. Descarte da água do lavador de gases;

c. Descarte de soluções com $\mathrm{UF}_{4}$.

2. Processo Ligas Especiais:

a. Descarte de soluções de decapagem do $U^{\circ}$;

b. Descarte da água do lavador de gases;

C. Emissões gasosas de lavadores de gases.

3. Processo Mecânico-Metalúrgico:

a. Descarte de soluções da decapagem $\left(\mathrm{NaOH}\right.$ e $\left.\mathrm{HNO}_{3}\right)$.

4. Processo Recuperação de Urânio:

a. Emissão de vapores para o sistema de exaustão;

b. Descarte da solução de Filtração.

5. Processo Administrativo:

a. Descarte de lâmpadas fluorescentes;

b. Descarte de resíduos orgânicos.

Assim, conclui-se que os principais aspectos que podem causar a contaminação do meio ambiente estão relacionados com os efluentes líquidos e gasosos no processo produtivo do combustível nuclear.

\subsection{Gerenciamento de Efluentes}

Nos últimos vinte e cinco anos vem crescendo a preocupação com a problemática ambiental por parte de vários grupos da sociedade em virtude da crescente degradação do meio ambiente e a necessidade da manutenção dos mesmos para as gerações futuras [48].

Problemas gerados por esta degradação como poluição do ar e dos recursos hídricos, contaminação do solo, extinção de espécies animais e vegetais, mudanças climáticas e esgotamento de alguns recursos naturais, tem sido considerado uma prioridade não somente para o Estado, mas também para muitas organizações [48]. 
É nesse contexto que se insere o caso da indústria, que tem sido considerada um dos agentes causadores desse impasse, em virtude do impacto direto que causam ao meio ambiente, como o desmatamento para a implantação de empreendimentos, a produção e geração de materiais inservíveis (resíduos), o destino inadequado desses resíduos e efluentes produzidos, emissão de gases do efeito estufa, entre outros [48].

Porém, nos últimos anos, as questões ambientais tem conquistado espaço e relevância e sendo incorporadas ao planejamento de muitas organizações, que tem buscado novas técnicas e tecnologias para serem aplicadas tanto durante seus processos, visando, por exemplo, a eliminação do desperdício de matéria-prima, o que irá reduzir a quantidade de resíduo solido produzido, como também visando serem aplicadas em uma fase posterior ao seu processo produtivo, ou seja, no destino que dão aos resíduos e efluentes. [48].

Os resíduos e efluentes industriais são um dos principais responsáveis pelos danos ambientais, já que são constituídos em geral de materiais que contém substâncias que alteram a composição do solo, da água e afetam a vida animal e vegetal, o que acaba causando desequilíbrios ecológicos. Apesar dos avanços da tecnologia em soluções que minimizem o impacto dos resíduos e efluentes no meio ambiente, ainda existe o impacto. O próprio processo de despoluição traz um determinado grau de impacto, pois utiliza substâncias químicas. No que tange a questão dos resíduos, vale ressaltar que os mesmos não podem ser destruídos, mas apenas transformá-los, minimizando o impacto e volume [48].

Atualmente, existem disponíveis um grande número de técnicas de tratamento. Essas técnicas de tratamento vão das tecnologias mais simples até as tecnologias mais avançadas [49]. Os processos de tratamento são classificados em físicos, químicos e biológicos, conforme a natureza dos poluentes a serem removidos e/ou das operações unitárias utilizadas para o tratamento [50].

Os processos físicos são aqueles que removem os sólidos em suspensão sedimentáveis e flutuantes através de separações físicas, tais como 
gradeamento, peneiramento, caixas separadoras de óleos e gorduras, sedimentação e flotação. Além disso, também é possível remover matéria orgânica e inorgânica em suspensão coloidal e reduzir ou eliminar a presença de microrganismos por meio de processos de filtração em areia ou em membranas (microfiltração e ultrafiltração) [50].

Processos químicos são os processos que utilizam produtos químicos, tais como: agentes de coagulantes, floculantes, neutralização de pH com ácido ou base. Esses produtos conseguem remover os poluentes por meio de reações químicas, além de condicionar a mistura de efluentes que será tratada nos processos subsequentes [50].

Seus principais processos são:

- Clarificação química;

- Eletrocoagulação;

- Precipitação de fosfatos e outros sais (remoção de nutrientes), pela adição de coagulantes químicos, compostos de ferro e ou alumínio;

- Cloração para desinfecção;

- Oxidação por ozônio, para a desinfecção;

- Redução do cromo hexavalente;

- Oxidação de cianetos;

- Precipitação de metais tóxicos;

- Troca iônica.

Já o tratamento por processos biológicos de esgotos e efluentes industriais tem o objetivo de remover a matéria orgânica dissolvida e em suspensão ao transformá-la em sólidos sedimentáveis (flocos biológicos) e gases. Basicamente, o tratamento biológico reproduz os fenômenos que ocorrem na natureza, mas em menor tempo [50].

Seus principais processos são: 
- Processos aeróbios, que são representados por lodos ativados e suas variantes, tais como, aeração prolongada, lodos ativados convencionais, lagoas aeradas facultativas e aeradas aeróbias;

- Processos facultativos, que são realizados pela utilização de biofilmes (filtros biológicos, biodiscos e biocontactores) e por algumas lagoas (fotossintéticas e aeradas facultativas).

- Os processos anaeróbios ocorrem em lagoas anaeróbias e biodigestores.

Essas tecnologias podem ser utilizadas isoladamente, ou então, pode-se desenvolver sistemas que utilizem uma combinação entre duas ou mais técnicas, para a obtenção de melhores resultados. Os critérios para a escolha de uma determinada tecnologia, bem como a definição de um sistema de tratamento devem ser definidos com base nas necessidades de cada indústria, onde devem ser considerados fatores como, ramo de atividade, localização geográfica, recursos hídricos disponíveis, processos produtivos, possibilidade de reutilização da água ou modificação do processo e restrições com relação à liberação de efluentes para o meio ambiente [49].

\subsubsection{Gerenciamento de Efluentes em Plantas Nucleares}

Em 2012 a U.S Nuclear Regulatory Commission (NRC) procurou conselhos da National Academies (NA) a respeito das análises dos riscos de câncer em populações que vivem perto de plantas de energia nuclear, esse projeto foi desenvolvido em duas fases e a primeira fase ficou pronta ainda em 2012 [25].

Na primeira fase foi realizado um estudo de escopo, no qual o comitê incluiu a identificação de abordagens científicas para " realizar o estudo de epidemiologia do câncer solicitado pelo NRC, " incluindo abordagens metodológicas para avaliação de dose e risco de câncer (estudo de populações, áreas geográficas, tipos de câncer, disponibilidade de dados de câncer) [25].

O relatório inicial da primeira fase relata questões gerais envolvidas em 
fornecer descrições válidas cientificamente sobre esses riscos, sugere dois projetos distintos fazendo maiores considerações e também propõe um trabalho adicional no qual avalia a viabilidade e o custo dos novos projetos [25, 29].

Esses estudos sobre câncer em populações que vivem perto de instalações nucleares vêm sendo desenvolvidos nas últimas duas décadas, a única razão científica é avaliar se as doses de radiação para populações vizinhas resultam em um aumento detectável no risco de câncer. Caso seja possível chegar a esta conclusão uma maior atenção terá que ser tomada tanto no descomissionamento dessas instalações como no tratamento de seus efluentes [26].

A operação de plantas nucleares gera grande quantidade de materiais radiativos assim como efluentes convencionais. Em uma instalação de energia nuclear, uma pequena fração dessas fontes radioativas é geralmente descarregada para o meio ambiente através de efluentes gasosos e líquidos. Esses efluentes radioativos geralmente são originários de várias fontes tais como: a fissão do urânio tramp, que é dissolvido das hastes de combustível expostas e revestido na estrutura do sistema refrigerante; vazamentos de barras de combustível falidas; a difusão de gases radioativos através de barras de combustível intactas; a ativação de materiais na água de resfriamento do reator; e corrosão de materiais ativados de tubos, válvulas, bombas e equipamentos auxiliares [28].

Portanto, o gerenciamento dos efluentes e rejeitos radioativos das usinas nucleares, do ponto de vista de proteção radiológica, consiste basicamente em três grandes temas:

- Desenvolver e implementar ações que minimizem, ou quando possível, eliminem a geração;

- Manter um sistema de controle e contabilização que permita conhecer as características dos efluentes e rejeitos, traçando indicadores que revelem o desempenho e as tendências da usina, e fornecendo dados que comprovem a aderência às normas do órgão regulador nacional; 
- Armazenar os rejeitos sólidos gerados de maneira segura, garantindo que a integridade física dos embalados seja mantida e que não haja impacto para a população e o meio ambiente [29].

Em um estudo realizado nas Plantas de Energia Nuclear da Coréia, foi analisado a liberação de efluentes radioativos líquidos e gasosos dessas plantas e os efeitos que causam nas doses anuais para o público. Os resultados mostraram que os efluentes gasosos contribuem mais para a radiação total do que os efluentes líquidos, mas mesmo que as centrais nucleares coreanas descarregassem alguns materiais radioativos no ambiente, todos os efluentes estavam dentro dos limites de segurança e as doses resultantes eram muito menores do que os limites de dose [28].

Todo ano a Agência Internacional de Energia Atômica publica uma review do panorama nuclear tecnológico [30], e no ano de 2016 os principais fatos que podemos destacar foram:

- Atualmente, existem 441 usinas de energia nuclear em operação em todo o mundo, e outras 157 estão encerrando ou estão em processo de descomissionamento, incluindo 17 que foram completamente descomissionadas.

- Existem mais de 320 instalações do ciclo do combustível em operação, cerca de 170 que foram encerradas ou estão em processo de descomissionamento e 125 que foram completamente descomissionadas. Existem também 246 reatores de pesquisa em operação e mais de 180 que foram encerrados ou estão em processo de descomissionamento. Mais de 300 reatores de pesquisa e montagens críticas foram completamente desarmados.

- As opções de eliminação de fontes radioativas seladas desocupadas, incluindo a co-eliminação com outros resíduos em instalações adequadas, um aumento no número de opções de reciclagem e repatriamento, ou disposição em furos dedicados, estão sendo consideradas em vários países. 
- As operações de incineração comercial e fusão de metais em vários países, como a Suécia e os EUA, continuam a oferecer oportunidades para serviços de tratamento de resíduos radioativos economicamente viáveis através das fronteiras.

- Melhorias em segurança continuam sendo feitas em centrais nucleares ao redor do mundo. Isso inclui identificar e aplicar lições aprendidas com o acidente de Fukushima, melhorando a eficácia da defesa em profundidade; fortalecendo a capacidade de preparação e resposta de emergência; mantendo e reforçando a capacitação; e protegendo as pessoas e o meio ambiente de radiações ionizantes.

Continuando ainda no tema de descomissionamento de instalações nucleares, na Suécia até 2020 metade de seus 13 reatores serão descomissionados. Essa ação será um grande desafio para todos envolvidos pois envolve muitas regulamentações. Assim, os suecos desenvolveram um trabalho sobre os aspectos administrativos envolvidos no descomissionamento dos reatores no qual poderão propor uma revisão sobre o processo de licenciamento de acordo com o Enviromental Act [31].

Além de estudos voltados para o descomissionamento de instalações nucleares, outra área que é realizado novos estudos é o de desenvolvimento de novos tratamentos de efluentes.

O reator comercial mais antigo da Coréia do Sul, Kori UNit 1, estará encerrando suas atividades a partir de 2017. Com o descomissionamento da central nuclear irá gerar uma grande quantidade de efluentes metálicos radioativos, e para um encerramento eficaz o fator-chave é um adequado tratamento dos efluentes. Para esse tipo de efluente o tratamento mais indicado seria o derretimento dos metais por fusão, mas atualmente na Coréia não existe nenhuma planta que execute isso. De acordo com o trabalho desenvolvido por SEO et al. (2017), estabeleceu-se um programa de manejo e gerenciamento para os resíduos sólidos metálicos avaliando as doses preliminares de acordo com os critérios de aceitação e operações na instalação [32]. 
Com base nos documentos de pesquisa disponíveis e nos dados empíricos da experiência nacional e internacional, o conceito operacional e o princípio da tecnologia de fusão foram estabelecidos e seus efeitos de redução de dose e volume foram avaliados. O conceito de operar uma planta de fusão é liberar livremente os lingotes após a fusão ou a liberação livre após um período de armazenamento planejado [32].

O sistema de gerenciamento de resíduos líquidos é uma instalação de armazenamento e tratamento de resíduos radioativos nas usinas nucleares, 0 qual tem como função garantir o gerenciamento seguro de resíduos radioativos gerados no processo de operação [32].

Materiais e processos, novos e melhorados, estão continuamente em desenvolvimento em vários países para reduzir a geração de resíduos e minimizar os custos. Para atender a crescente pressão para reduzir a liberação de radioativos para o meio ambiente KIM, J.; KIM, C. (2017) discute as possíveis melhorias de desempenho do sistema de gerenciamento de resíduos líquidos existente no Advanced Power Reactor 1400 (APR-1400) sem a instalação de equipamentos adicionais ou mudanças de design do sistema [33].

A principal geração de efluentes líquidos radioativos provém do processo de limpeza e manutenção do reator e sistemas relacionados. O tratamento dos resíduos radioativos líquidos geralmente envolve a aplicação de várias etapas, tais como filtração, precipitação, sorção, troca iônica, evaporação e /ou separação por membrana em atendimento aos requisitos tanto para liberação dos efluentes descontaminados quanto para 0 condicionamento de concentrados de resíduos para descarte [33].

O estudo desenvolvido por KIM, J.; KIM, C. (2017) propõe três opções possíveis para a melhoria do sistema de gerenciamento de resíduos líquidos no reator APR1400: adições químicas, aumento da seletividade de permuta iónica e condições de operação ótimas para reduzir a concentração de radioatividade na geração de efluentes e resíduos sólidos [33].

GARCIA, D. Z.; WERSHOFEN, H. (2017) apresenta o desenvolvimento de métodos radioquímicos para a separação simultânea de vários radionuclídeos em amostras de concreto, aço e grafite, com base em 
tratamentos de amostra individuais que se fundem em um procedimento comum de separação radioquímica baseado em cromatografia de extração [34].

Os efluentes radioativos gerados nas atividades de descomissionamento devem ser classificados de acordo com seu conteúdo radioativo. A informação radiológica exigida pelas autoridades nacionais inclui diversos emissores alfa e beta, que só podem ser determinados após um processo de separação radioquímica [34].

Em outro estudo, PLAGNES et al. (2017) desenvolveu um balanço hídrico para prever a estratégia de gerenciamento de um sistema de efluentes da fábrica de processamento de urânio. As operações de mineração e moagem, como a desidratação no poço ou a liberação de efluentes tratados, podem potencialmente influenciar a hidrologia e a qualidade da água ao redor das operações [35].

O trabalho realizado apresenta a metodologia utilizada para prever os volumes de água e a qualidade da água que descarregam a jusante em corpos d'água de superfície. Um modelo de compartimento representando os três lagos incluídos no sistema de gerenciamento foi configurado usando o software GoldSim®. O balanço da água irá permitir prever o volume do lago diariamente, e um modelo de balanço de massa desenvolvido para elementos conservadores também foi desenvolvido e permite validar as proporções de entradas e saídas emitidas a partir do modelo de balanço hídrico. Esse modelo foi então utilizado como ferramenta preditiva para avaliar o impacto de diferentes cenários de gerenciamento de efluentes, em volumes e química de águas superficiais, para períodos de tempo curtos e mais longos [35].

Um benefício significativo desse modelo é que ele pode ser usado como uma entrada para a modelagem geoquímica para prever as concentrações de todos os constituintes de interesse na água de superfície receptora [35].

Além do desenvolvimento de novos tratamentos para os efluentes das instalações nucleares, também houve avanços de novos tratamentos para efluentes gerados no ciclo do combustível nuclear. A recuperação do urânio tem a vantagem de salvar esse valioso metal e evitar o descarte inaceitável da 
solução de diuranato de amônio para o meio ambiente. Devido ao alto custo envolvido no processo de recuperação, vários métodos foram desenvolvidos para recuperar urânio de efluentes.

No trabalho desenvolvido por OTHMAN et al. (2005), sintetizou-se um filtro de tecido incorporando ácido acrilonitrilo / ácido metacílico para recuperação de urânio a partir de efluentes radioativos. A incorporação dos grupos funcionais foi confirmada por espectro FT-R. O filtro possui boas propriedades mecânicas e estabilidade térmica e química adequada para uso prático. A taxa de captação de urânio atingiu $95 \%$ a $25^{\circ} \mathrm{C}$ e pH 9,5 [36].

Em outro estudo, CHAUDHURY, S.; MUDHER, K. D. S.; VENUGOPAL, V. (2003) desenvolveram um método simples de separação e recuperação de urânio em utilizando $\mathrm{CaF}_{2}$ e $\mathrm{MgF}_{2}$. Esse processo emprega uma reação no estado sólido, aquecendo a mistura de urânio-escória com $(\mathrm{NH} 4)_{2} \mathrm{SO}_{4}$ a $350^{\circ} \mathrm{C}$ formando compostos de sulfato de urânio, cálcio e/ou magnésio. O sulfato de urânio é separado por dissolução em ácido diluído. Por esse método, cerca de 95\% do urânio presente pode ser recuperado [37].

De acordo com o trabalho de CARVALHO et al. (2017), esses desenvolveram uma metodologia de recuperação de urânio a partir das escórias, a qual é proveniente do processo de produção de urânio metálico por redução magnesiotérmica. Por esse método, cerca de $96 \%$ do urânio presente na escória pode ser recuperada e retornado ao processo produtivo [38].

O urânio é o elemento importante nas aplicações nucleares. Por essa razão, a remoção e recuperação de urânio são de grande importância devido ao efeito prejudicial ao meio ambiente. A remoção de urânio em tratamentos de efluentes radioativos é um dos maiores problemas devido à dificuldade em tratar por métodos convencionais de tratamento. O processo de sorção tem sido utilizado na remoção de metais pesados e outros materiais perigosos, tais como cor, odor e poluição orgânica [46, 47].

Muitos trabalhos foram publicados na sorção de urânio a partir de soluções aquosas em diferentes adsorvedores [39 - 41]. Entre os numerosos adsorventes, o carvão ativo é o mais utilizado e provou ser eficaz para a remoção de vários poluentes das águas residuais. Contudo, os processos de 
carbono ativo são processos de adsorção caro por causa do alto custo do carbono ativo [44].

Nos últimos anos, há um interesse crescente em usar materiais de baixo custo ecológico e materiais adsorvedores comercialmente disponíveis para a absorção de íons de urânio, como cascas de laranja por MAHMOUD, A. (2014), palma por KUSHWAHA S., SUDHAKAR P. P. (2013), palha de arroz por YAKOUT et al. (2013), esferas de celulose por RULE P., GONTE R. R. (2014), girassol, verbena e grama da guiné roxa por KASETSART, J. (2010) [39-43].

No estudo que SENEDA et al. (2001) realizou, eles desenvolveram um processo tecnicamente viável para separar e concentrar o urânio da solução de fluoreto de amônio, mantendo um complexo aniônico de fluoreto de uranilo em uma resina, limpando o flúor do sistema com o uso de solução diluída de carbonato de amônio e eluindo o urânio com uma solução mais concentrada de carbonato de amônio. O flúor é dessorvido de forma eficaz e a solução de carbonato de uranilo como produto final está livre de fluoreto [45]. 


\section{Materiais e Métodos}

Descreve-se os estudos realizados no desenvolvimento e definição do método a ser aplicado visando alcançar os objetivos propostos nesse trabalho.

a) Verificação e análise da legislação ambiental vigente no país; Inicialmente foi feito um levantamento bibliográfico focando na legislação ambiental vigente e de interesse para identificar os aspectos e impactos ambientais significativos; [7,8,17-19,21,22]

b) Analise do fluxo do processo de produção do combustível nuclear;

Nessa etapa foi realizada uma avaliação detalhada do processo produtivo de elementos combustíveis no $\mathrm{CCN}$, visando coletar dados que permitam identificar e caracterizar todos os processos. O levantamento de dados foi feito por meio de: (1) acompanhamento do processo produtivo, (2) consulta e avaliação de documentos técnicos existentes sobre o objeto de estudo e (3) esclarecimento junto aos responsáveis pela condução dos processos e/ou atividades selecionadas no estudo;

c) Coleta de amostras dos efluentes gerados;

d) Caracterização de todos os efluentes (líquidos e sólidos) radioativos e convencionais gerados durante o processo de fabricação de elementos combustíveis, levando em consideração os parâmetros físicos e contaminantes específicos;

e) Levantamento qualitativo e quantitativo dos efluentes produzidos;

Levantamento das considerações sobre o impacto desses resíduos e efluentes gera ao meio ambiente;

f) Avaliação e definição da Segregação dos efluentes de modo a agrupar os que requerem o mesmo tratamento, separando-os dos que requerem tratamentos específicos. 


\subsection{Caracterização química dos efluentes gerados no processo produtivo}

A caracterização dos efluentes identificados no processo produtivo do combustível nuclear foi realizada de três maneiras: (1) a partir do resultado de análises já realizadas anteriormente; (2) análises de amostras coletadas durante o processo de produção do combustível nuclear; e (3) coleta de amostras de efluentes que estavam armazenados.

A coleta das amostras era realizada em recipientes de plásticos devido a presença de fluoreto. A quantidade variava entre $20 \mathrm{ml}$ a $30 \mathrm{ml}$ para os efluentes líquidos e $15 \mathrm{~g}$ a $20 \mathrm{~g}$ para os sólidos.

As análises não eram realizadas no próprio centro (CCN), e sim encaminhadas para o CQMA. Na Tabela 3.1 estão especificadas as análises realizadas pelo CQMA e suas respectivas metodologias.

Tabela 3.1 Análises realizas no CQMA.

\begin{tabular}{|c|c|}
\hline Ánalises & Método Analítico \\
\hline Teor de urânio $\left(\mu \mathrm{g} \mathrm{ml}^{-1}\right)$ & \multirow{4}{*}{$\begin{array}{l}\text { Espectroscopia de emissão óptica com } \\
\text { plasma }\end{array}$} \\
\hline Teor de alumínio $\left(\mu \mathrm{g} \mathrm{ml}^{-1}\right)$ & \\
\hline Teor de sódio $\left(\mu \mathrm{g} \mathrm{ml}^{-1}\right)$ & \\
\hline Teor de estanho $\left(\mu \mathrm{g} \mathrm{ml}^{-1}\right)$ & \\
\hline Teor de fluoreto $\left(\mu \mathrm{g} \mathrm{ml}^{-1}\right)$ & \multirow{5}{*}{ Cromatografia de íons } \\
\hline Teor de cloreto $\left(\mu \mathrm{g} \mathrm{ml}^{-1}\right)$ & \\
\hline Teor de amônia $\left(\mu \mathrm{g} \mathrm{ml}^{-1}\right)$ & \\
\hline Teor de nitrato $\left(\mu \mathrm{g} \mathrm{ml}^{-1}\right)$ & \\
\hline Teor de magnésio $\left(\mu \mathrm{g} \mathrm{ml}^{-1}\right)$ & \\
\hline Razão isotópica (em peso de ${ }^{235} \mathrm{U}$ ) & Espectrometria de massa \\
\hline
\end{tabular}

As análises mais simples, utilizadas apenas para reconhecimento de valores, são realizadas pelo próprio $\mathrm{CCN}$, tais como: $\mathrm{pH}$, densidade e concentração de fluoreto com eletrodo de íons. 


\section{Resultados e Discussão}

4.1 Avaliação dos efluentes gerados no processo produtivo do elemento combustível

Para o desenvolvimento do trabalho foi realizado um acompanhamento do processo de produção do elemento combustível no $\mathrm{CCN}$, o que tornou possível indicar os tipos de efluentes que eram gerados em cada etapa do processo. Em toda a rota adotada geram-se efluentes líquidos, gasosos, sólidos.

Figura 4.1 Efluentes gerados no processo de produção do EC.

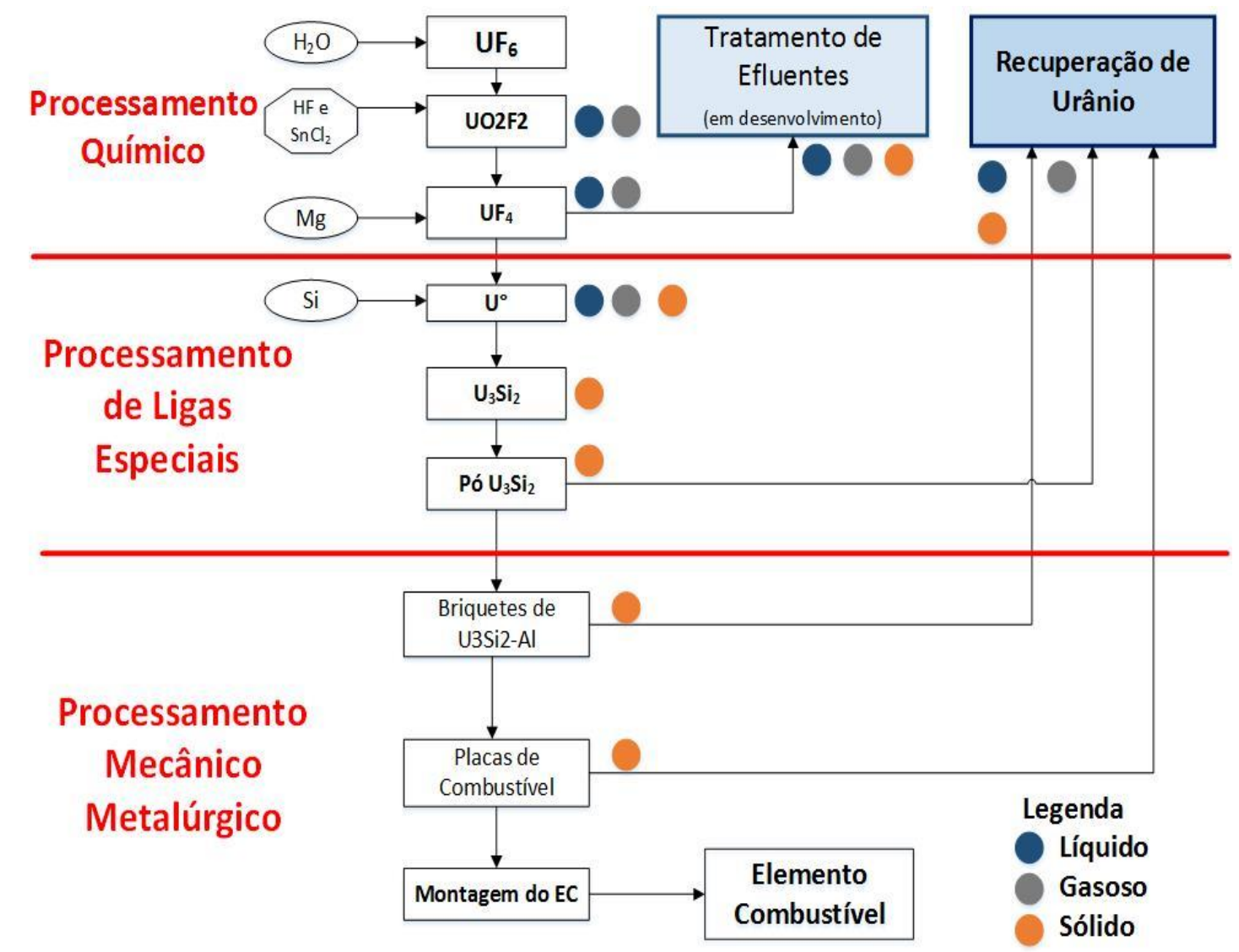

Fonte: Autora da dissertação.

Para um resultado mais detalhados, é apresentada na Tabela 4.1 os três setores do CCN associado às etapas do processo de produção do EC e os respectivos efluentes gerados, e ainda se destacam os efluentes que são radioativos. 
Tabela 4.1 Efluentes gerados no processo de produção do EC.

\begin{tabular}{|c|c|c|}
\hline Setor & Etapas Processo & Efluentes \\
\hline \multirow{11}{*}{$\begin{array}{l}\text { Processamento } \\
\text { Químico }\end{array}$} & \multirow{2}{*}{ Reconversão de $U_{6}$} & Efluente $\mathrm{UF}_{4}$ \\
\hline & & Redução da Água de Cristalização \\
\hline & \multirow{4}{*}{ Recuperação de Urânio } & Efluente DUA \\
\hline & & Solução Aquosa amoniacal \\
\hline & & Solução Orgânica \\
\hline & & Solução Aluminato de Sódio \\
\hline & \multirow{5}{*}{$\begin{array}{l}\text { Tratamento de Efluentes } \\
\text { Industriais }\end{array}$} & Água dos Lavadores de Gases \\
\hline & & $\begin{array}{l}\text { Solução Ácida (análises realizadas } \\
\text { no CQMA) }\end{array}$ \\
\hline & & $\begin{array}{l}\text { Solução Aquosa (sistema de } \\
\text { emergência) }\end{array}$ \\
\hline & & Restos de Amostras \\
\hline & & Sólidos de Limpeza \\
\hline \multirow{6}{*}{$\begin{array}{l}\text { Processamento de } \\
\text { Ligas Especiais }\end{array}$} & \multirow{6}{*}{$\begin{array}{l}\text { Redução e Fusão de } \\
\text { Ligas }\end{array}$} & Escória I $\left(\mathrm{MgF}_{2}\right)$ \\
\hline & & Solução Ácida (decapagem Uº) \\
\hline & & Solução Aquosa (Decapagem Uº) \\
\hline & & Cadinho de Grafite \\
\hline & & Cadinho de Zircônia \\
\hline & & $\begin{array}{l}\text { Solução de Álcool (tratamento } \\
\text { lignote) }\end{array}$ \\
\hline \multirow{7}{*}{$\begin{array}{l}\text { Processamento } \\
\text { Mecânico- } \\
\text { Metalúrgico }\end{array}$} & \multirow{2}{*}{$\begin{array}{l}\text { Processamento de Pós e } \\
\text { Briquetes }\end{array}$} & Solução Nítrica \\
\hline & & Briquetes fora da especificação \\
\hline & \multirow{4}{*}{$\begin{array}{l}\text { Fabricação de Placas e } \\
\text { Montagem do EC }\end{array}$} & Fragmentos de Alumínio \\
\hline & & $\begin{array}{l}\text { Solução Ácido Nítrico (decapagem } \\
\text { placas) }\end{array}$ \\
\hline & & $\begin{array}{l}\text { Solução de Hidróxido de Sódio } \\
\text { (decapagem placas) }\end{array}$ \\
\hline & & Placas rejeitadas \\
\hline & $\begin{array}{l}\text { Metrologia e Controle de } \\
\text { Processo }\end{array}$ & $\begin{array}{l}\text { Solução Aquosa (análise } \\
\text { metalográfica) }\end{array}$ \\
\hline
\end{tabular}

Efluentes radioativos

Fonte: Autora da dissertação.

\subsection{Caracterização química dos efluentes gerados no processo produtivo}

Após identificado os efluentes gerados, iniciou-se o estudo de caracterização química desses. A caracterização foi realizada a partir da coleta de amostras dos efluentes gerados e enviados ao Centro de Química e meio 
Ambiente - CQMA do IPEN/CNEN-SP para análises. A Tabela 4.2 apresenta as principais análises utilizadas para a caracterização dos efluentes.

Tabela 4.2 Análises utilizadas na caracterização dos efluentes.

\begin{tabular}{|c|c|}
\hline Amostra & Análises \\
\hline Solução Aluminato de sódio & $\begin{array}{l}\text { Teor de urânio }\left(\mu \mathrm{g} \mathrm{mL}^{-1}\right) \\
\text { Teor de alumínio }\left(\mu \mathrm{gL}^{-1}\right) \\
\text { Teor de sódio }\left(\mu \mathrm{gL}^{-1}\right) \\
\mathrm{pH}\end{array}$ \\
\hline Efluente do $\mathrm{UF}_{4}$ & $\begin{array}{l}\text { Teor de urânio }\left(\mu \mathrm{g} \mathrm{mL}^{-1}\right) \\
\text { Teor de estanho } \\
\text { Teor de fluoreto }\left(\mu \mathrm{gL}^{-1}\right) \\
\text { Teor de cloreto }\left(\mu \mathrm{gL}^{-1}\right) \\
\text { pH }\end{array}$ \\
\hline Efluente do DUA & $\begin{array}{l}\text { Teor de urânio }\left(\mu g \mathrm{~mL}^{-1}\right) \\
\text { Teor amônia }\left(\mathrm{g} \mathrm{L}^{-1}\right) \\
\text { Teor de fluoreto }\left(\mathrm{g} \mathrm{L}^{-1}\right) \\
\mathrm{pH}\end{array}$ \\
\hline Fase orgânica (TBP) & $\begin{array}{l}\text { Teor de urânio } \\
\text { Densidade }\end{array}$ \\
\hline $\begin{array}{l}\text { Permeado-Troca iônica } \\
\text { (desenvolvimento) }\end{array}$ & $\begin{array}{l}\mathrm{pH} \\
\text { Teor de fluoreto }\left(\mu \mathrm{g} \mathrm{mL}^{-1}\right) \\
\text { Teor de nitrato }\left(\mu \mathrm{gL}^{-1}\right) \\
\text { Teor de amônia }\left(\mu \mathrm{gL}^{-1}\right) \\
\text { Teor de urânio }\left(\mu \mathrm{gL}^{-1}\right)\end{array}$ \\
\hline Água dos lavadores gases & $\begin{array}{l}\mathrm{pH} \\
\text { Teor de fluoreto }\left(\mu \mathrm{g} \mathrm{mL}^{-1}\right) \\
\text { Teor de nitrato }\left(\mu \mathrm{gL}^{-1}\right) \\
\text { Teor de amônia }\left(\mu \mathrm{gL}^{-1}\right) \\
\text { Teor de urânio }\left(\mu \mathrm{gL} \mathrm{m}^{-1}\right)\end{array}$ \\
\hline Escorias de $U^{\circ}$ & $\begin{array}{l}\text { Teor de urânio }\left(\mathrm{g} \mathrm{kg}^{-1}\right) \\
\text { Teor de } \mathrm{Mg}\left(\mathrm{g} \mathrm{kg}^{-1}\right) \\
\text { Teor de Fluoreto }\left(\mu \mathrm{gL}^{-1}\right)\end{array}$ \\
\hline $\begin{array}{l}\text { Soluções contendo urânio e } \\
\text { refugos }\end{array}$ & Razão isotópica (em peso de ${ }^{235} \mathrm{U}$ ) \\
\hline
\end{tabular}

Fonte: Descrição das Atividades e Operações - Centro do Combustível Nuclear (2007)

São apresentados nas Tabelas 4.3 a 4.5 os resultados dos efluentes líquidos, gasosos e sólidos gerados, respectivamente. Nessas tabelas são fornecidas as quantidades geradas, a etapa do processo em que são gerados, a caracterização química e o método de tratamento aplicado. 
Tabela 4.3 Efluentes líquidos gerados no processo produtivo do EC. (continua)

\begin{tabular}{|c|c|c|c|c|c|}
\hline Item & Efluente & Quantidade & $\begin{array}{c}\text { Etapa } \\
\text { Processo }\end{array}$ & Caracterização & Tratamento \\
\hline A & Efluente $\mathrm{UF}_{4}$ & $\begin{array}{c}40 \text { litros por } \\
\text { batelada de EC }\end{array}$ & $\mathrm{RC}$ & $\begin{array}{c}{\left[\mathrm{U}^{+6}\right]=120 \mu \mathrm{g} \cdot \mathrm{mL}^{-1}} \\
{\left[\mathrm{Sn}^{+2}\right]=20 \mathrm{~g} \cdot \mathrm{L}^{-1}} \\
{\left[\mathrm{~F}^{-}\right]=47 \mu \mathrm{g} \cdot \mathrm{mL}^{-1}} \\
{[\mathrm{Cl}]=12 \mu \mathrm{g} \cdot \mathrm{mL}^{-1}} \\
\mathrm{pH} 2,43\end{array}$ & Em desenvolvimento. \\
\hline B & $\begin{array}{l}\text { Solução Ácida } \\
\text { (Decapagem U) }\end{array}$ & $\begin{array}{c}300 \mathrm{ml} \text { para cada } \\
\text { decapagem. } \\
\mathrm{HNO}_{3} \text { puro }\end{array}$ & $\mathrm{RF}$ & {$\left[\mathrm{U}^{+6}\right]<2,3 \mu \mathrm{g} \cdot \mathrm{mL}^{-1}$} & $\begin{array}{l}\text { Precipitado como DUA. Calcinado a } \\
\mathrm{UO}_{3} \text {. Retorna a linha produtiva como } \\
\mathrm{UF}_{4} \text {. }\end{array}$ \\
\hline
\end{tabular}

C Solução Aquosa

$300 \mathrm{ml}$ para cada decapagem

RF

$\left[\mathrm{U}^{+6}\right]<0,5 \mu \mathrm{g} \cdot \mathrm{mL}^{-1}$
Descarte depois de autorizado pela proteção radiológica ambiental após análise do teor de urânio e de acordo com o CONAMA N²0.

\begin{tabular}{|c|c|c|c|c|c|}
\hline D & $\begin{array}{l}\text { Álcool proveniente do } \\
\text { tratamento de superficial } \\
\text { das placas de } \cup_{3} S_{i 2}\end{array}$ & $\begin{array}{l}20 \text { L/Elemento } \\
\text { combustível }\end{array}$ & FPM & - & $\begin{array}{l}\text { Reutilizado como álcool técnico nas } \\
\text { instalações produtivas do CCN. }\end{array}$ \\
\hline E & $\begin{array}{l}\text { Solução aquosa } \\
\text { proveniente de lavagens } \\
\text { de peneiras } \\
\text { granulométricas e/ou } \\
\text { equipamentos utilizadas } \\
\text { no processo de produção }\end{array}$ & $\begin{array}{l}0,5 \mathrm{~L} \text { a cada } \mathrm{EC} \\
\text { produzido }\end{array}$ & PPB & $\mathrm{pH} 6,7$ & $\begin{array}{l}\text { Decantação do pó de urânio. } \\
\text { Separação do sobrenadante. } \\
\text { Controle do teor de urânio. Descarte } \\
\text { depois de autorizado pela proteção } \\
\text { radiológica ambiental, de acordo com } \\
\text { o CONAMA N²0. }\end{array}$ \\
\hline
\end{tabular}

Tabela 4.3 Efluentes líquidos gerados no processo produtivo do EC. (continuação) 
Solução de ácido nítrico

F proveniente do processo

de decapagem das

placas combustíveis
$\mathrm{HNO}_{3} 30 \%$

FPM

$\mathrm{pH} 3$

Solução é enviada ao CCR para reutilização em limpeza e descontaminação de reatores, filtros, dissolução de urânio (Recuperação de Urânio).
Solução de hidróxido de

G Sódio proveniente do processo de decapagem das placas combustíveis
$30 \mathrm{~L}$ de $\mathrm{NaOH} 2,5 \mathrm{M}$

FPM

$\mathrm{pH} 6$
Solução é enviada ao CCR para reutilização no processo de dissolução de placas combustíveis (Recuperação de Urânio).

\section{H Efluente DUA}

$200 \mathrm{~L} / 10$ placas

$\mathrm{RU}$

$$
\begin{gathered}
{\left[\mathrm{U}^{+6}\right]=8,5 \pm 1,5 \mu \mathrm{g} \cdot \mathrm{mL}^{-1}} \\
{\left[\mathrm{NH}_{4}^{+}\right]=8,8 \pm 0,8 \mathrm{~g} \cdot \mathrm{L}^{-1}} \\
{\left[\mathrm{~F}^{-}\right]=69 \pm 1,8 \mu \mathrm{g} \cdot \mathrm{mL}^{-1}} \\
\mathrm{pH} 9,2
\end{gathered}
$$

\begin{tabular}{|c|c|c|c|c|c|}
\hline I & $\begin{array}{l}\text { Solução aquosa } \\
\text { proveniente da } \\
\text { recuperação do urânio }\end{array}$ & $\begin{array}{c}15 \mathrm{~L} \text { por } \\
\text { batelada/10placas }\end{array}$ & $\mathrm{RU}$ & {$\left[\mathrm{U}^{+6}\right]=1,96 \pm 0,12 \mu \mathrm{g} \cdot \mathrm{mL}^{-1}$} & $\begin{array}{l}\text { Análise e Descarte de acordo com } 0 \\
\text { CONAMA N } 20 .\end{array}$ \\
\hline $\mathbf{J}$ & $\begin{array}{l}\text { Solução orgânica } \\
\text { proveniente da } \\
\text { recuperação do urânio } \\
\text { TBP (tributil fosfato) }\end{array}$ & $\begin{array}{c}15 \mathrm{~L} \text { por } \\
\text { batelada/10placas }\end{array}$ & $\mathrm{RU}$ & $\begin{array}{l}{\left[\mathrm{U}^{+6}\right]=97,7 \pm 0,5 \mu \mathrm{g} \cdot \mathrm{mL}^{-1}} \\
{\left[\mathrm{U}^{+6}\right]=10,2 \pm 0,3 \mu \mathrm{g} \cdot \mathrm{mL}^{-1}}\end{array}$ & $\begin{array}{l}\text { Lavar com carbonato de sódio. } \\
\text { Lavar com } \mathrm{HNO}_{3} . \\
\text { Lavar com água até } \mathrm{pH} 7 . \\
\text { Lavar com } \mathrm{HNO}_{3} \\
\sim 100 \text { L: ESTOCADO. }\end{array}$ \\
\hline
\end{tabular}

Troca lônica e o Urânio recuperado com carbonato de uranilo.

Tabela 4.3 Efluentes líquidos gerados no processo produtivo do EC.

(continuação) 


\begin{tabular}{|c|c|c|c|c|c|}
\hline K & $\begin{array}{l}\text { Solução ácida } \\
\text { proveniente de análises } \\
\text { químicas de controle do } \\
\text { combustível realizadas } \\
\text { no CQMA e retornadas } \\
\text { ao CCN }\end{array}$ & $\begin{array}{l}\text { A cada } 3 \text { meses de } \\
\text { produção gera } 5 \mathrm{~L} \\
\text { de solução de } \\
\text { urânio purificado }\end{array}$ & TEI & $\begin{array}{l}{\left[\mathrm{U}^{+6}\right]=15 \mu \mathrm{g} \cdot \mathrm{mL}^{-1}} \\
{\left[\mathrm{NO}_{3}^{-}\right]=80 \mathrm{mg} \cdot \mathrm{L}^{-1}}\end{array}$ & $\begin{array}{l}\text { Precipitado como DUA. Calcinado a } \\
\mathrm{UO}_{3} \text {. Retorna a linha produtiva como } \\
\mathrm{UF}_{4} \text {. }\end{array}$ \\
\hline $\mathbf{L}$ & $\begin{array}{l}\text { Solução aquosa } \\
\text { proveniente do sistema } \\
\text { de lava olhos e chuveiros } \\
\text { de emergência }\end{array}$ & - & TEI & $\begin{array}{l}\text { Não se aplica, pois até o } \\
\text { momento não houve a } \\
\text { necessidade de se utilizar o } \\
\text { sistema de emergência }\end{array}$ & $\begin{array}{l}\text { Descartado de acordo com a proteção } \\
\text { radiológica ambiental após análise de } \\
\text { teor de urânio conforme o CONAMA } \\
20 \text {. }\end{array}$ \\
\hline M & $\begin{array}{l}\text { Solução aquosa gerada } \\
\text { nas análises } \\
\text { metalográfica }\end{array}$ & $\begin{array}{l}\text { Solução } \\
\text { armazenada em } \\
\text { um tanque de } \\
2000 \mathrm{~L}\end{array}$ & MCP & $\begin{array}{c}{\left[\mathrm{NO}_{3}{ }^{2-}\right]=0,24 \mu \mathrm{g} \cdot \mathrm{mL}^{-1}} \\
{\left[\mathrm{~F}^{-}\right]=0,38 \mu \mathrm{g} \cdot \mathrm{mL}^{-1}}\end{array}$ & $\begin{array}{l}\text { Descartado de acordo com a Proteção } \\
\text { Radiológica ambiental após análise de } \\
\text { teor de urânio, atividade e pH } \\
\text { CONAMA } 20 .\end{array}$ \\
\hline $\mathbf{N}$ & $\begin{array}{l}\text { Aluminato de sódio } \\
\text { proveniente da } \\
\text { dissolução de placas } \\
\text { combustíveis }\end{array}$ & $60-80$ L/batelada & $\mathrm{RU}$ & $\begin{array}{c}{\left[\mathrm{U}^{+6}\right]=18 \mu \mathrm{g} \cdot \mathrm{mL}^{-1}} \\
{\left[\mathrm{Na}^{+}\right]=24 \mu \mathrm{g} \cdot \mathrm{mL}^{-1}} \\
{[\mathrm{Al}]=38 \mathrm{~g} \cdot \mathrm{L}^{-1}}\end{array}$ & Em desenvolvimento. \\
\hline
\end{tabular}

Fonte: Autora da dissertação.

Tabela 4.4 Efluentes gasosos gerados no processo produtivo do EC.

\begin{tabular}{lllll}
\hline Item & Efluente & Quantidade & $\begin{array}{c}\text { Etapa do } \\
\text { Processo }\end{array}$ & Caracterização \\
\hline
\end{tabular}




\begin{tabular}{|c|c|c|c|c|c|}
\hline 0 & $\begin{array}{l}\text { Lavador de } \\
\text { Gás CCR }\end{array}$ & 200 L/ano & $\begin{array}{l}\text { RC } \\
\text { RU } \\
\text { TEI }\end{array}$ & $\begin{array}{c}{\left[\mathrm{F}^{-}\right]=106,24 \mu \mathrm{g} \cdot \mathrm{mL}^{-1}} \\
{\left[\mathrm{NO}_{3}{ }^{2-}\right]=3,59 \mu \mathrm{g} \cdot \mathrm{mL}^{-1}} \\
{\left[\mathrm{U}^{+6}\right]<0,05 \mu \mathrm{g} \cdot \mathrm{mL}^{-1}} \\
{\left[\mathrm{Sn}^{+2}\right]=2,60 \pm 0,09 \mu \mathrm{g} \cdot \mathrm{L}^{-1}} \\
\mathrm{pH} 6,5\end{array}$ & $\begin{array}{c}\text { Controle de } 3 \text { em } 3 \text { meses verificando teor } \\
\text { de Urânio. } \\
\text { Troca da água uma vez ao ano. } \\
\text { Descarte da água após análise. }\end{array}$ \\
\hline $\mathbf{P}$ & $\begin{array}{l}\text { Lavador de } \\
\text { Gás CCL }\end{array}$ & 200 L/ano & $\mathrm{RF}$ & $\begin{array}{c}{\left[\mathrm{F}^{-}\right]=6,58 \mu \mathrm{g} \cdot \mathrm{mL}^{-1}} \\
{\left[\mathrm{Sn}^{+2}\right]=0,60 \pm 0,09 \mu \mathrm{g} \cdot \mathrm{L}^{-1}} \\
{\left[\mathrm{NO}_{3}\right]=0,16 \mu \mathrm{g} \cdot \mathrm{mL}^{-1}} \\
{\left[\mathrm{U}^{+6}\right]<0,05 \mu \mathrm{g} \cdot \mathrm{mL}^{-1}} \\
\mathrm{pH} 6,8\end{array}$ & $\begin{array}{c}\text { Controle de } 3 \text { em } 3 \text { meses verificando teor } \\
\text { de Urânio. } \\
\text { Troca da água uma vez ao ano. } \\
\text { Descarte da água após análise. }\end{array}$ \\
\hline $\mathbf{Q}$ & $\begin{array}{l}\text { Lavador de } \\
\text { Gás CCP }\end{array}$ & 200 L/ano & $\begin{array}{l}\text { PPM } \\
\text { FPM }\end{array}$ & $\begin{array}{c}{\left[\mathrm{U}^{+6}\right]<0,05 \mu \mathrm{g} \cdot \mathrm{mL}^{-1}} \\
{\left[\mathrm{NO}_{3}^{2-}\right]=0,16 \mu \mathrm{g} \cdot \mathrm{mL}^{-1}} \\
\mathrm{pH} 7,2\end{array}$ & $\begin{array}{c}\text { Controle de } 3 \text { em } 3 \text { meses verificando teor } \\
\text { de Urânio. } \\
\text { Troca da água uma vez ao ano. } \\
\text { Descarte da água após análise. }\end{array}$ \\
\hline
\end{tabular}

Fonte: Autora da dissertação. 
Tabela 4.5 Efluentes sólidos gerados no processo produtivo do EC. (continua)

\begin{tabular}{|c|c|c|c|c|c|}
\hline Item & Efluente & Quantidade & $\begin{array}{c}\text { Etapa } \\
\text { processo }\end{array}$ & Caracterização & Tratamento \\
\hline $\mathbf{R}$ & Escória I- $\mathrm{MgF}_{2}$ & $5 \mathrm{Kg} /$ batelada & $\mathrm{RF}$ & {$\left[\mathrm{U}^{+6}\right]=118 \pm 4 \mu \mathrm{g} \cdot \mathrm{g}^{-1}$} & $\begin{array}{l}\text { Calcinação a } \cup_{3} \mathrm{O}_{8} \text {, dissolução do } \\
\text { urânio e purificação com extração } \\
\text { com solventes, precipitação de DUA, } \\
\text { calcinação a } \mathrm{UO}_{3} \text {, precipitação de } \\
\mathrm{UF}_{4} \text {. Retorna a linha produtiva. }\end{array}$ \\
\hline $\mathbf{S}$ & Cadinho de Grafite & $\begin{array}{l}1 \text { Cadinho para } 3 \\
\text { bateladas de } U^{0}\end{array}$ & RF & $\begin{array}{c}10 \mathrm{~g} \text { de urânio/cadinho } \\
\text { quebrado }\end{array}$ & $\begin{array}{l}\text { Lixiviação do urânio nos cadinhos. } \\
\text { Possível reuso do grafite (em } \\
\text { desenvolvimento). }\end{array}$ \\
\hline $\mathbf{T}$ & Cadinho de Zircônia & $\begin{array}{l}2 \text { a } 3 \text { cadinhos/ } \\
\text { batelada. }\end{array}$ & $\mathrm{RF}$ & $\begin{array}{c}20 \mathrm{~g} \text { de urânio/cadinho } \\
\text { quebrado }\end{array}$ & $\begin{array}{l}\text { Lixiviação do urânio nos cadinhos. } \\
\text { Possível reuso do zircônio (em } \\
\text { desenvolvimento). }\end{array}$ \\
\hline $\mathbf{U}$ & Escória II & $3-4 \mathrm{Kg}$ & $\mathrm{RU}$ & {$\left[\mathrm{U}^{+6}\right]=0,087 \pm 0,003 \mu \mathrm{g} \cdot \mathrm{g}^{-1}$} & $\begin{array}{l}\text { Obtenção de cadinhos de } \mathrm{MgF}_{2} \text { (em } \\
\text { desenvolvimento). }\end{array}$ \\
\hline $\mathbf{V}$ & Placas, Briquetes e Pós & $\begin{array}{l}10 \text { placas ou } 10 \\
\text { briquetes por } \\
\text { batelada }\end{array}$ & PPM & $\begin{array}{l}\text { Briquete e/ou Placas } \\
70-80 \mathrm{~g} \text { de urânio }\end{array}$ & $\begin{array}{l}\text { Dissolução do alumínio e do urânio, } \\
\text { purificação do } U \text { com extração de } \\
\text { solventes, precipitação de DUA, } \\
\text { calcinação a } U_{3} \text {, precipitação de } \\
\text { UF }_{4} \text {. Retorna a linha produtiva. }\end{array}$ \\
\hline W & Fragmentos de Alumínio & $\begin{array}{l}1 \text { EC gera } 2 \mathrm{Kg} \\
\text { de alumínio }\end{array}$ & FPM & - & Sucata (reciclagem) \\
\hline
\end{tabular}


Tabela 4.5 Efluentes sólidos gerados no processo produtivo do EC.

(continuação)

Sólidos de limpeza de

X capelas, pias, tanques de

estocagem contendo urânio

Restos de amostras

utilizadas em análises de

controle do elemento

combustível

z Resina acrílica contendo urânio embutido

Fonte: Autora da dissertação.
Dissolução do urânio. Precipitação de DUA, calcinação a $\cup_{3}$. Incorporado ao pó recuperado. Retorna a linha produtiva como $\mathrm{UF}_{4}$ ou $\mathrm{U}_{3} \mathrm{O}_{8}$.

Dissolução urânio.

Precipitação de DUA,

Calcinação a $\mathrm{UO}_{3}$. Incorporado ao pó recuperado. Retorna a linha produtiva como $\mathrm{UF}_{4}$.

Estocado (sem desenvolvimento).
7 amostras embutidas/EC
$38 \mathrm{mg}$ 
Os efluentes e os rejeitos originados nas áreas produtivas do CCN são coletados, no local de origem, de forma segregada, de acordo com o estado físico, composição química e radiológica. Durante o tempo de coleta esses recipientes são mantidos em suportes plásticos identificados e posteriormente enviados para reciclagem.

Atualmente, no $\mathrm{CCN}$ a classe de efluentes líquidos considera-se uma subdivisão em efluentes radioativos e convencionais. Em função da classificação adotada, os efluentes radioativos são coletados e encaminhados para tratamento e recuperação de urânio e para os efluentes sólidos e líquidos é prevista a sua armazenagem temporária, em tambores e tanques respectivamente, antes da destinação para a área de armazenagem ou tratamento local. Os tanques de armazenagem de efluentes líquidos ficam confinados em tanques de contenção em polietileno.

Os efluentes gasosos e líquidos são submetidos aos processos de tratamento para atender aos requisitos da Resolução n 357, de 17 de março de 2005, e a Resolução do $n^{\circ}$ 430, de 13 de maio de 2011 do Conselho Nacional do Meio Ambiente - CONAMA para posteriormente serem lançados ao meio ambiente $[21,22]$.

Nos processos operacionais da área de Reconversão $\mathrm{UF}_{6}$ (transferência de $\mathrm{UF}_{6}$ e obtenção do $\mathrm{UF}_{4}$ ) são gerados efluentes gasosos contendo urânio somente em caso de ocorrência de algum evento anormal na operação. Nas operações na área de Recuperação Urânio proveniente dos refugos da fabricação (efluentes sólidos) gera uma corrente de efluentes gasosos apresentando uma composição de traços de $\mathrm{NH}_{3}, \mathrm{NOx}$, $\mathrm{HF}$ e vapor d'água.

Os efluentes identificados como itens $\mathrm{B}, \mathrm{K}, \mathrm{R}, \mathrm{V}, \mathrm{X}, \mathrm{Y}$ podem ser segregados para tratamento e recuperação de urânio e fluoreto por possuírem características químicas semelhantes. Ressalta-se que deve ser avaliado a massa de urânio enriquecido a $19,75 \pm 0,20 \%$ em peso de $U^{235}$, para evitar problemas de criticalidade. Os procedimentos administrativos do CCN estabelecem a manipulação de processamento de massa segura.

Os efluentes gerados na decapagem das placas combustíveis tais como solução de ácido nítrico $(F)$ e solução de $\mathrm{NaOH}(G)$ são reutilizados no 
processo produtivo. A solução de ácido nítrico é utilizada na dissolução de escorias e pós de urânio fazendo somente o ajuste da concentração. A solução pode também ser utilizada na limpeza e descontaminação de reatores químicos, filtros, etc.

A solução $\mathrm{NaOH}$ segue a mesma filosofia. É utilizada no processamento e recuperação de placas combustíveis na etapa de dissolução do alumínio. Antes de seu uso realiza-se a análise para verificar a concentração de $\mathrm{NaOH}$, e posteriormente a correção da concentração para o referido uso.

O álcool, item $\mathrm{D}$, utilizado para secagem das placas combustíveis no processo de decapagem também é reutilizado na unidade produtiva como "álcool técnico". Outras tecnologias podem ser aplicadas, mas ainda não estão em desenvolvimento no CCN.

Os efluentes gasosos que correspondem aos lavadores de gases são na verdade efluentes líquidos, pois os gases gerados são coletados em um sistema de exaustão e então armazenados na forma líquida. Esse efluente juntamente com os efluentes líquidos tais como C, E, J, L e M são descartados na rede de esgoto comum. Essa ação é possível porque ao realizar a caracterização química os valores dos contaminantes encontram-se abaixo do nível permitido para o descarte.

Alguns efluentes estão ainda em fase de desenvolvimento, entre eles 0 efluente do $\mathrm{UF}_{4}$, cujo desenvolvimento envolve além da recuperação do urânio o retorno para o processo produtivo. Até o momento estuda-se a recuperação do fluoreto na forma de fluorita $\left(\mathrm{CaF}_{2}\right)$ que então pode ser utilizado na etapa de obtenção de urânio metálico. Para a recuperação do estanho analisa-se a viabilidade de usar carbonato de amônio $\left(\mathrm{NH}_{3} \mathrm{CO}_{2}\right)$. Outros efluentes que ainda estão em fase inicial de desenvolvimento são: os cadinhos de grafite (S) e os de zircônia $(T)$, escória II (U) e aluminato de sódio (N).

O único efluente orgânico gerado no processo é resultante da etapa de purificação do urânio, o tributil fosfato (TBP). Esse efluente é tratado, adequado quimicamente e reutilizado no processo de purificação por mais 4 bateladas de 10 placas combustíveis. Posterior a isto ele torna-se um rejeito radioativo com concentração de urânio de $10 \mu \mathrm{g}$ de U. $\mathrm{mL}^{-1}$. 
$\mathrm{Na}$ etapa de fabricação do EC são gerados fragmentos e retalhos de alumínio 6061, que são envasados para reciclagem.

A fim de apresentar resultados mais objetivos a respeito dos efluentes líquidos gerados e seus tratamentos, separaram os efluentes em quatro grupos: (1) efluentes que passam pelo processo de reconversão de urânio; (2) efluentes que são reutilizados no processo; (3) efluentes que são descartados ao meio ambiente; (4) efluentes que o tratamento está em fase de desenvolvimento.

Utilizando as informações fornecidas nas Tabelas 4.3 a respeito da quantidade de efluente gerado e tomando como base a produção de um elemento de combustível é possível dizer que $30 \%$ do efluente líquido possuem tratamento de recuperação de urânio retornando ao processo produtivo gerando efluente convencional onde a unidade de tratamento está sendo implantado. 20\% dos efluentes líquidos são reutilizados na composição química em que foi gerado, $35 \%$ descartado diretamente ao meio ambiente de acordo com a legislação. O restante dos efluentes líquidos, cerca de 15\%, estão em fase de desenvolvimento do processo de tratamento.

Utilizando o mesmo critério para os efluentes sólidos encontrou-se que cerca de $90 \%$ contém urânio, sendo 55\% tratado e recuperado o urânio, retornando ao processo produtivo.

Com intuito de fornecer uma visão mais geral do processo de produção do combustível nuclear juntamente com os respectivos efluentes gerados, elaborou-se a Figura 4.2.

Para a elaboração da respectiva figura, destacou-se as principais etapas do processo de produção do combustível nuclear, juntamente com os efluentes identificados nesse trabalho, sendo que para sua identificação utilizou-se os itens a eles associados na tabela de resultados (Tabelas 4.3 a 4.5 ).

Os círculos cinzas representam os efluentes gasosos, os azuis os efluentes líquidos e amarelos os efluentes sólidos. Para os efluentes que apresentam um contorno vermelho significa que a metodologia de tratamento ainda está em desenvolvimento. $\mathrm{O}$ contorno rosa representa os efluentes que 
se tornam rejeitos radioativos e o contorno verde é o efluente que será reciclado.

Além dos efluentes, tem-se as linhas do processo que são quatro: azul, vinho, verde e rosa. A linha azul representa os efluentes que possuem tratamento; a linha vinho representa os efluentes que irão para o setor de recuperação de urânio e a linha verde são os efluentes que são utilizados no processo de recuperação e, por último, a linha rosa representa o $U_{4} F_{4}$ que foi obtido a partir do processo de recuperação e que voltará para o processo. 
Figura 4.2 Diagrama geral do processo de produção do EC.

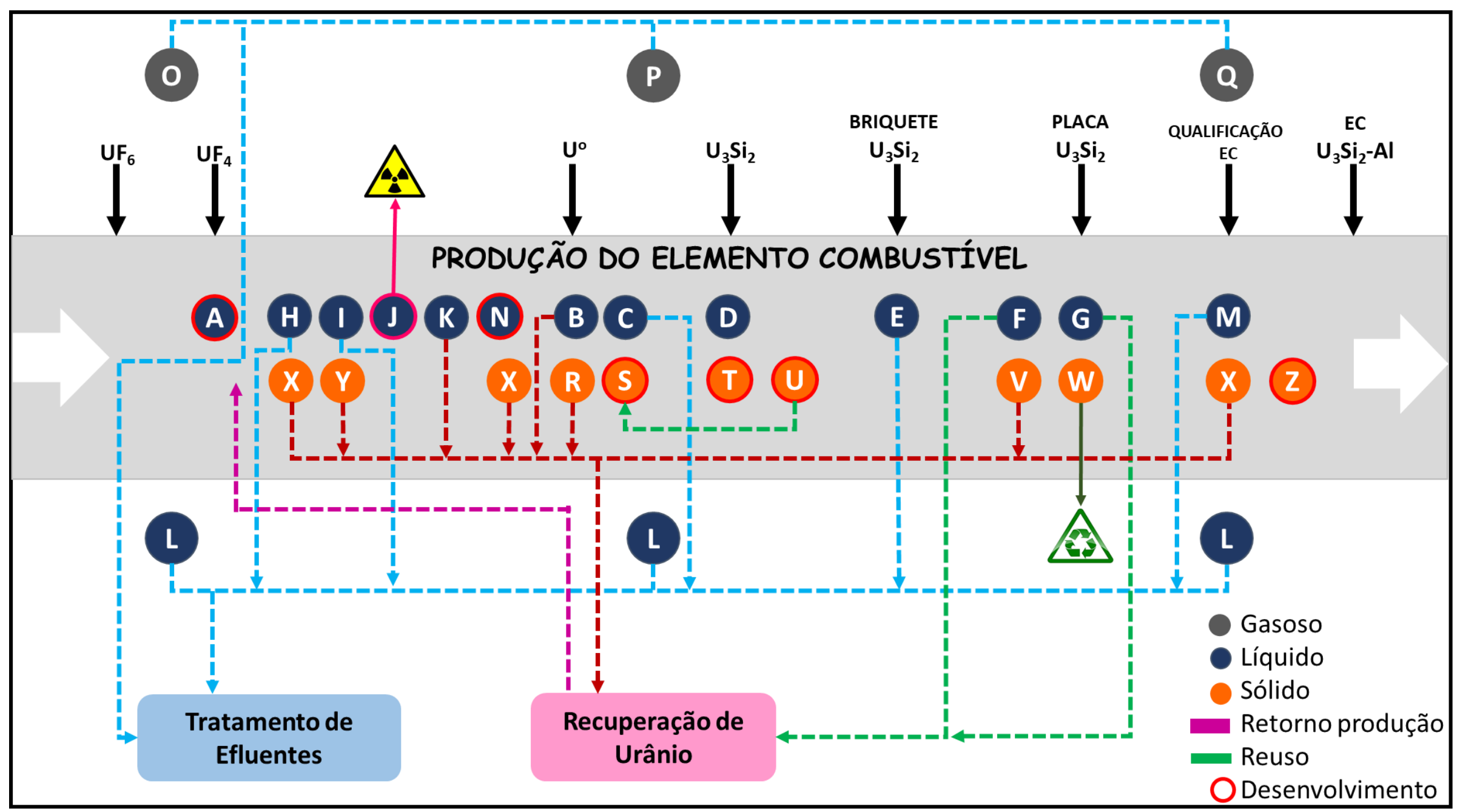

Fonte: Autora da dissertação. 


\subsection{Fluxograma do processo produtivo}

Como foi realizado o acompanhamento do processo de produção do combustível nuclear, foi possível presenciar as etapas mais detalhadamente e isso contribuiu para que se construísse um fluxograma de processo de produção do EC.

Como existem muitas etapas envolvidas no processo de produção do combustível nuclear, ao elaborar uma única imagem não seria possível realizar a impressão em uma folha tipo A4, portanto foi necessário separar algumas etapas. Para manter a apresentação já realizada até o momento, separou-se o processo nos seguintes blocos: reconversão do $\mathrm{UF}_{6}$, processamento de ligas especiais (o qual está dividido em duas partes), montagem do EC (foi separado em três partes), reconversão do urânio e tratamento dos efluentes contendo urânio. Cada bloco está representado nas Figuras 4.3 a 4.10.

Em cada bloco é foi destacado os principais produtos obtidos ao longo do processo por uma caixa de processo verde; os efluentes captados pelos lavadores de gases são representados por uma seta tracejada roxa; os efluentes que vão para o tratamento que contem urânio possuem uma seta tracejada azul; e os efluentes que irão passar pelo processo de recuperação de urânio apresentam uma seta tracejada verde e uma caixa indicativa de qual processo de recuperação este fará parte; os resíduos radioativos são representados por um seta de fluxo vermelha e uma caixa amarela.

Além disso, apresenta-se quais análises são realizadas em cada etapa do processo. Tem-se tanto as análises de qualificação dos produtos como as de caracterização física e química.

Na Figura 4.3 está representado a reconversão do UF6, a qual envolve as etapas de transferência de parte do $\mathrm{UF}_{6}$ do cilindro para uma ampola $1 \mathrm{~S}$ e, também, a obtenção do $\mathrm{UF}_{4}$ a partir de uma hidrólise.

As Figuras 4.4 e 4.5 representam as duas etapas que envolvem o bloco denominado como processamento de ligas especiais. A primeira etapa (Figura 4.4) é a obtenção do urânio metálico em um forno de redução e, a segunda etapa (Figura 4.5) é a produção do siliceto de urânio a partir da fusão do urânio 
metálico da etapa anterior com o sílicio.

O bloco que representa a montagem do EC foi dividido em três partes representado pelas Figuras 4.6 a 4.8 . A primeira parte representada pela Figura 4.6 tem-se a produção do briquete de $\mathrm{U}_{3} \mathrm{Si}_{2}-\mathrm{Al}$, na segunda parte (Figura 4.7) realiza-se a fabricação da placa combustível e, finalmente, para a terceira etapa representada pela Figura 4.8 tem-se a montagem do elemento combustível, onde é possível construir o EC padrão ou um EC de controle.

O próximo bloco, no qual é apresentado a recuperação de urânio na Figura 4.9 tem-se que a recuperação do urânio pode ser realizada de três maneiras: a partir de fragmentos de placas e briquetes, do pó que foi descartado e, também, a partir da escória I que contém fluoreto de magnésio.

Finalmente, na Figura 4.10 é apresentado o bloco em que ocorre o tratamento dos efluentes que contém urânio. Esses tratamentos são realizados em quatro vertentes: a partir do filtrado TCAU, do filtrado do $\mathrm{UF}_{4}$, do filtrado de DUA e da solução de TBP/VARSOL. Esse último, mesmo após o tratamento ainda conterá urânio em sua composição e por isso será armazenado, os outros tratamentos que geram novos efluentes serão encaminhados para 0 tratamento de efluentes convencionais para que atinjam as especificações necessárias para o descarte ao meio ambiente. 
Figura 4.3 Reconversão do UF 6 .

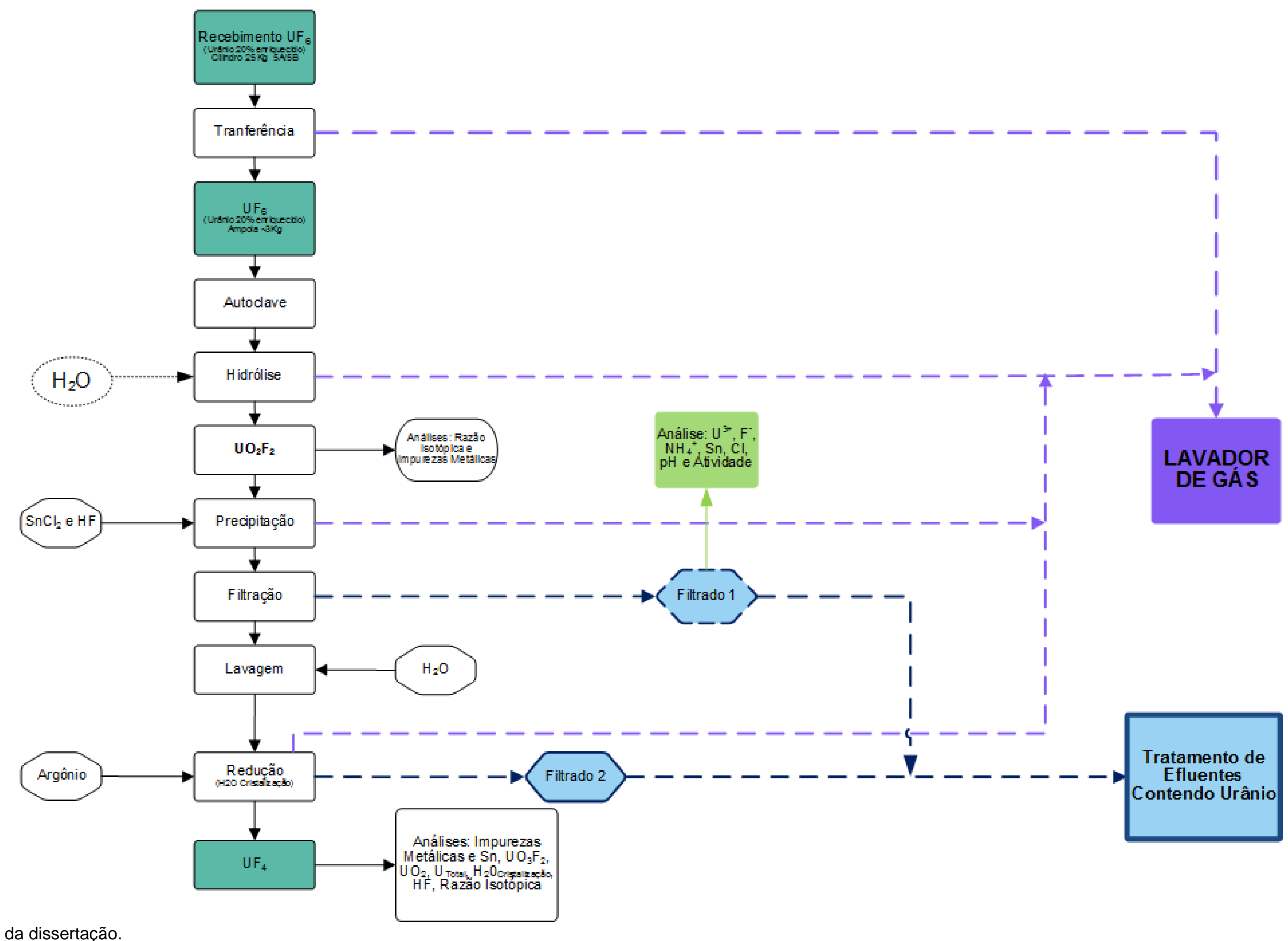

Fonte: Autora da dissertação. 
Figura 4.4 Processamento de ligas especiais - parte 1.

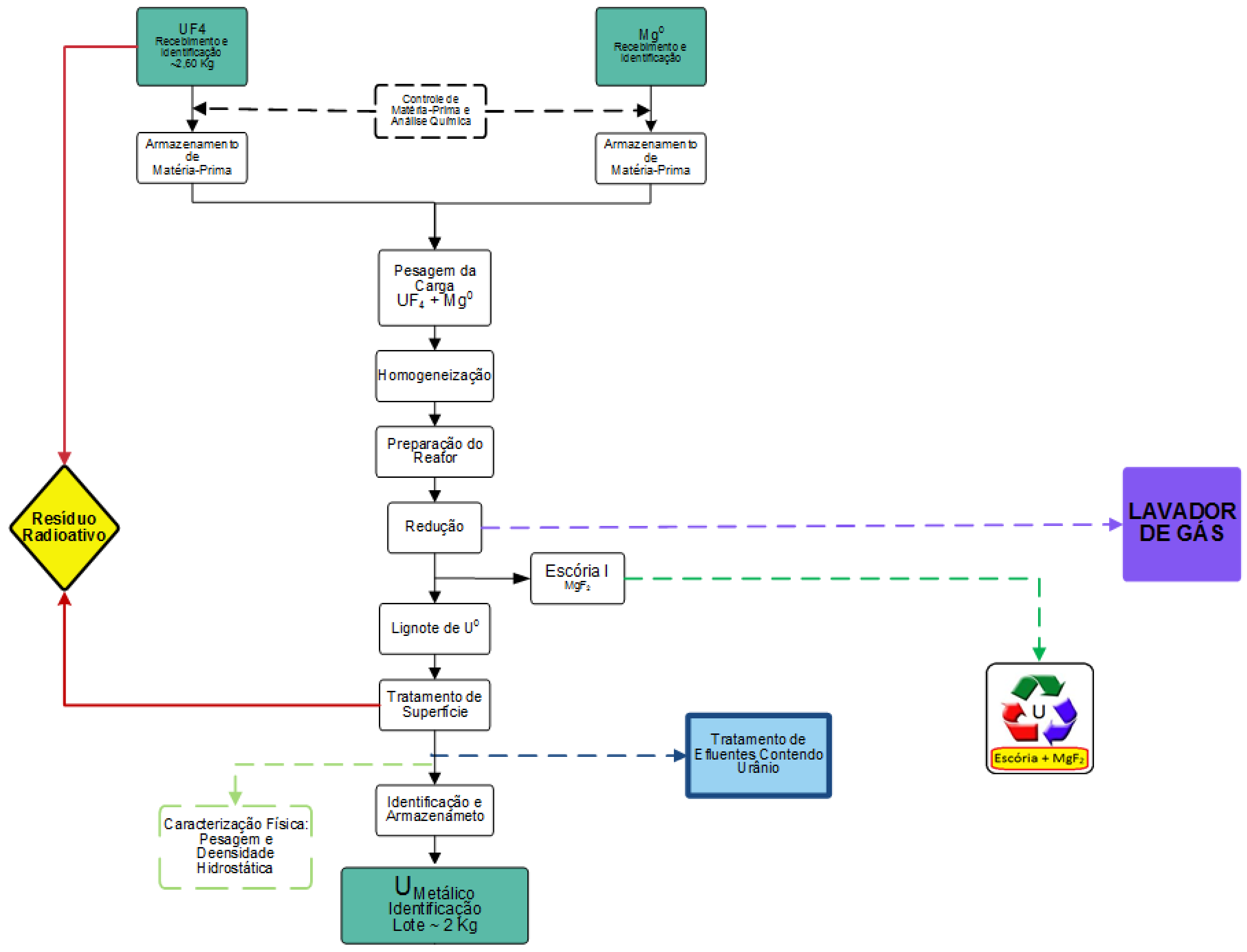

Fonte: Autora da dissertação 
Figura 4.5 Processamento de ligas especiais - parte 2.

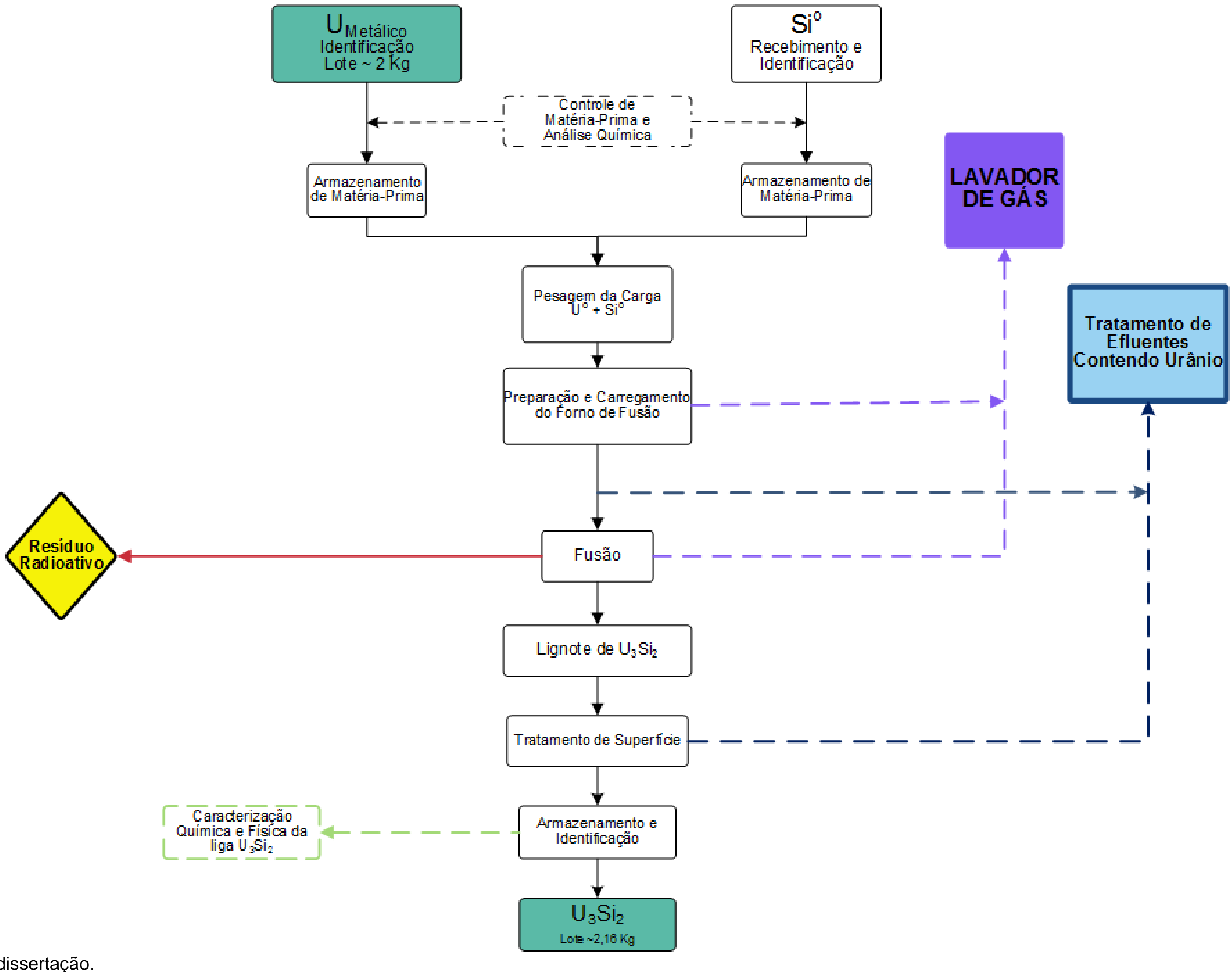

Fonte: Autora da dissertação. 
Figura 4.6 Montagem do EC - parte 1.

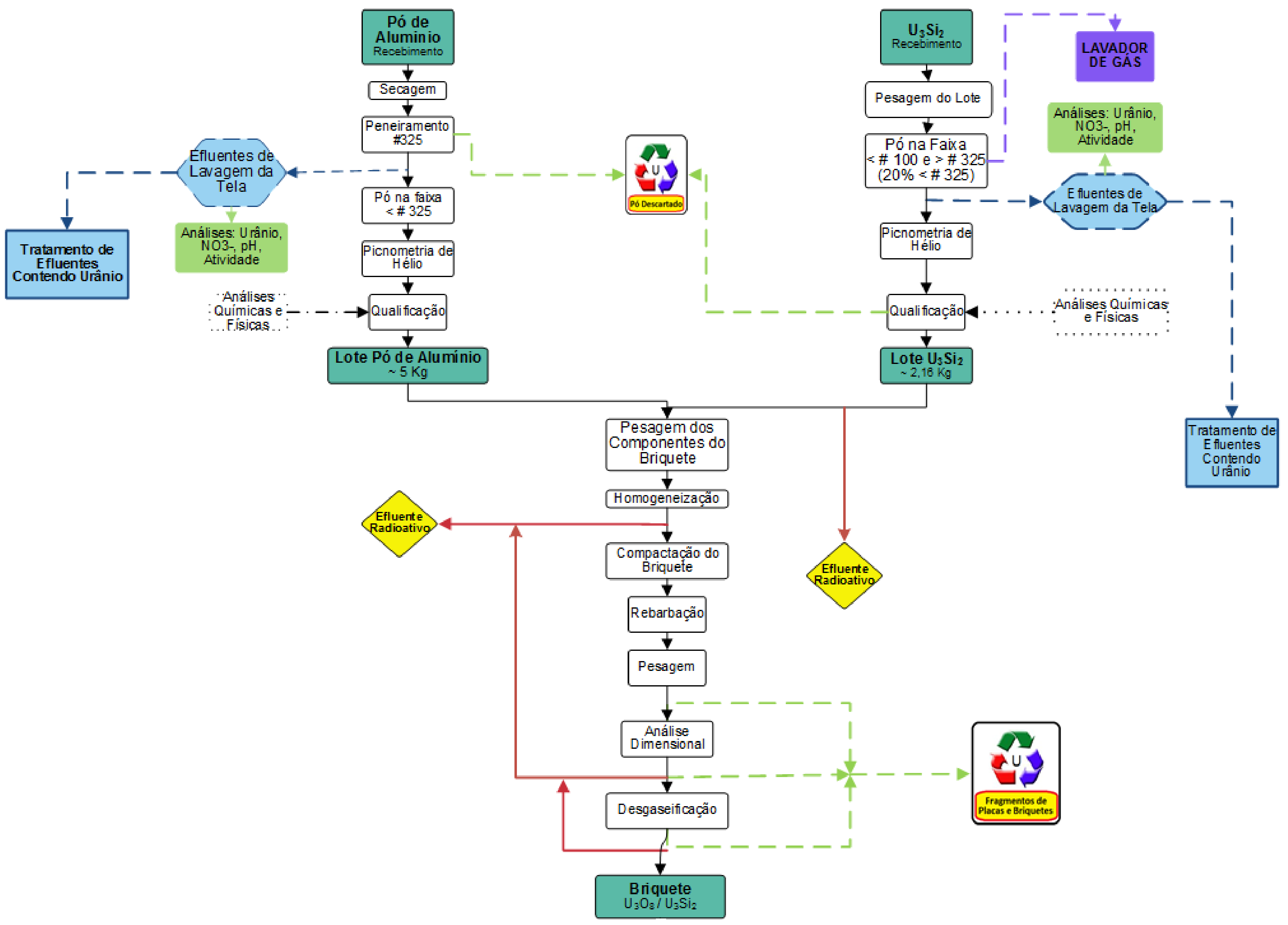




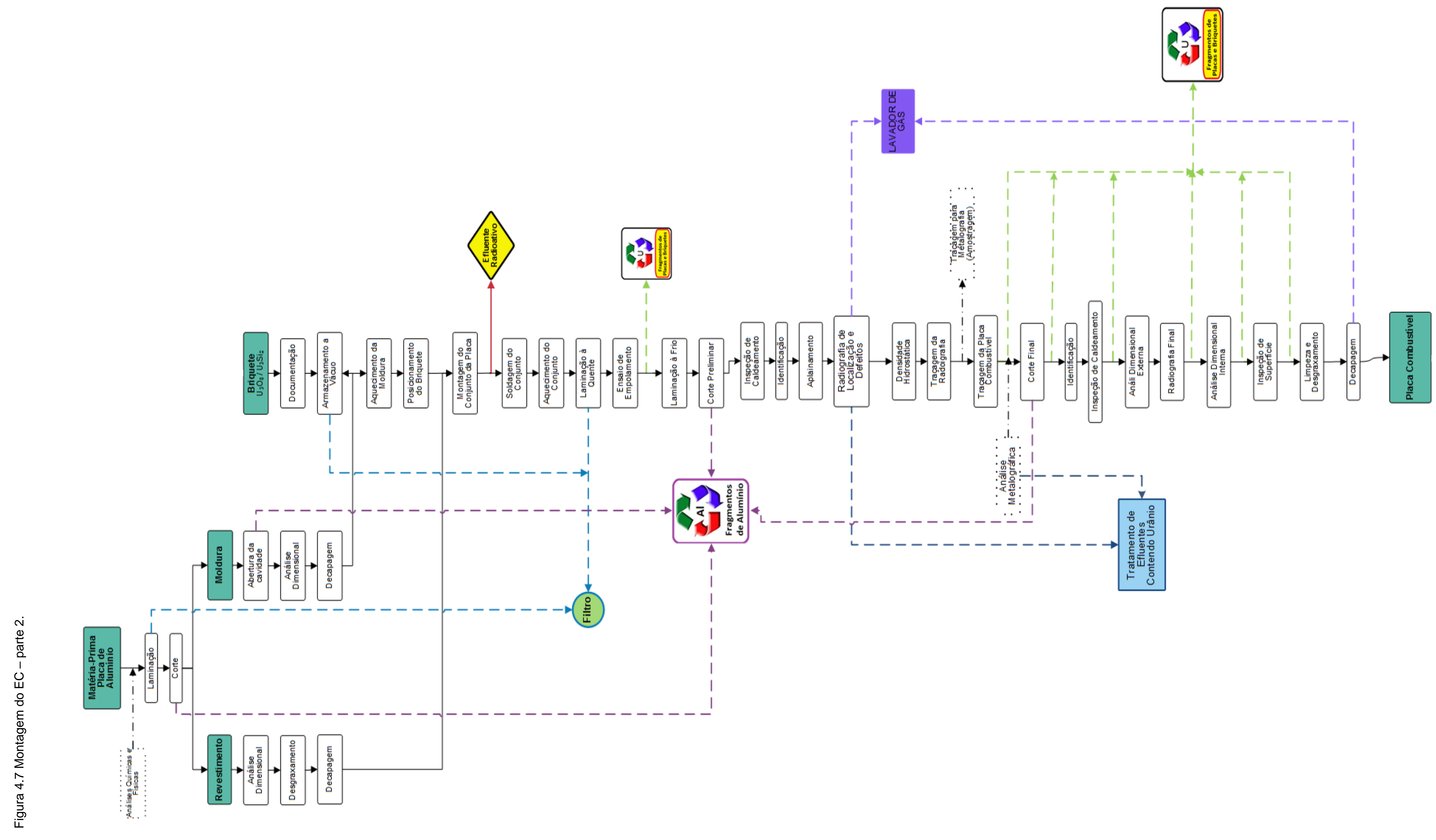


Figura 4.8 Montagem do EC - parte 3.

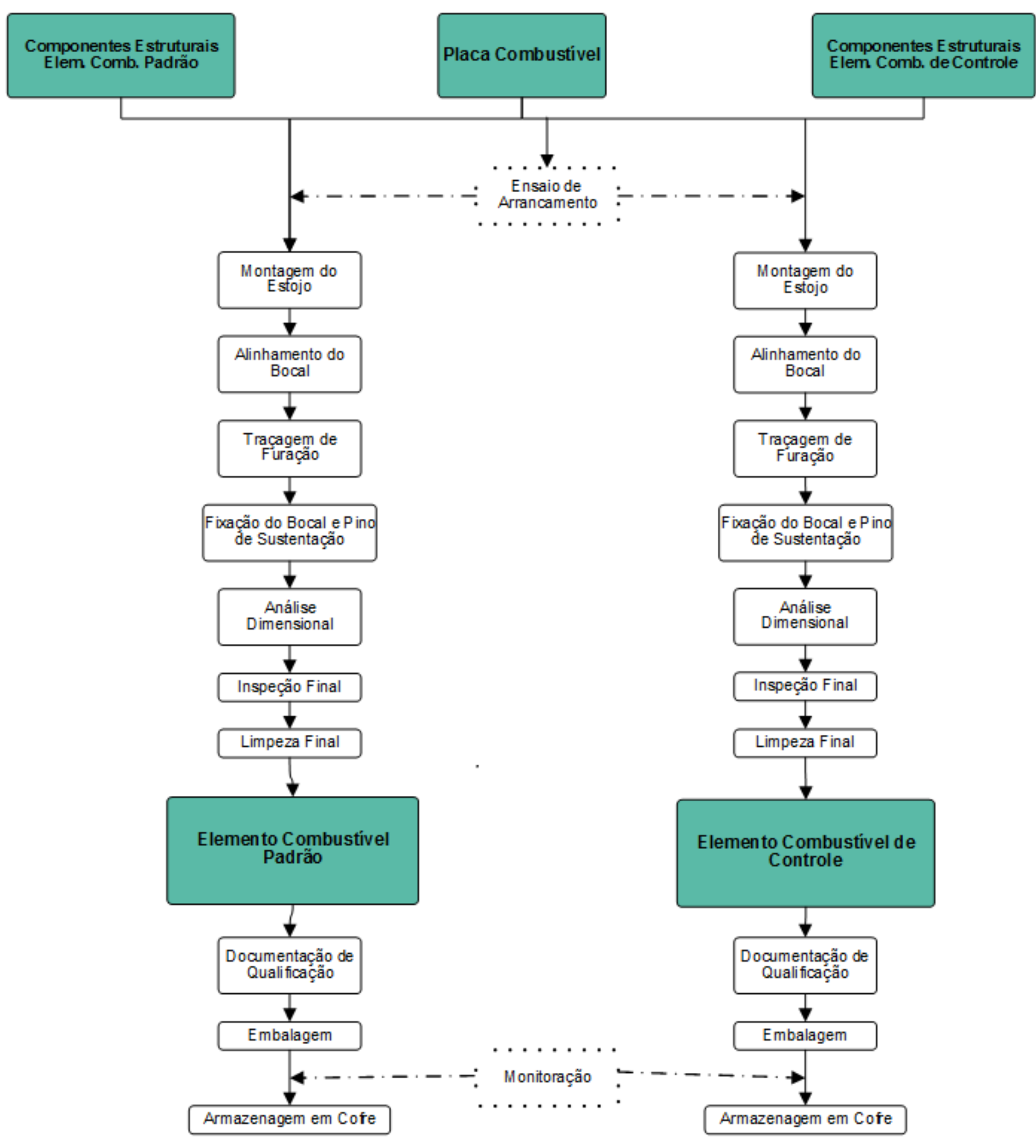

Fonte: Autora da dissertação. 
Figura 4.9 Recuperação de urânio.

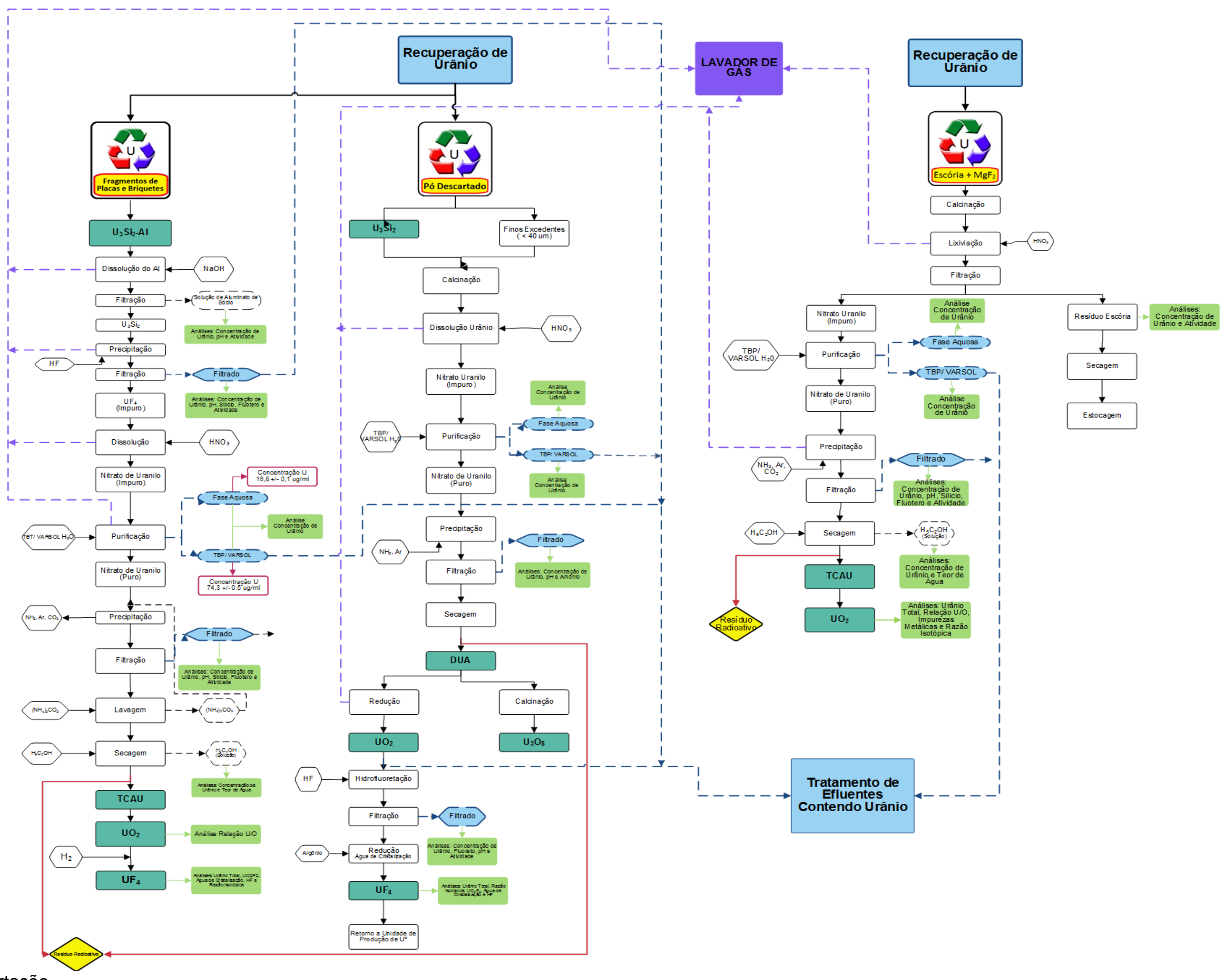

Fonte: Autora da dissertação. 


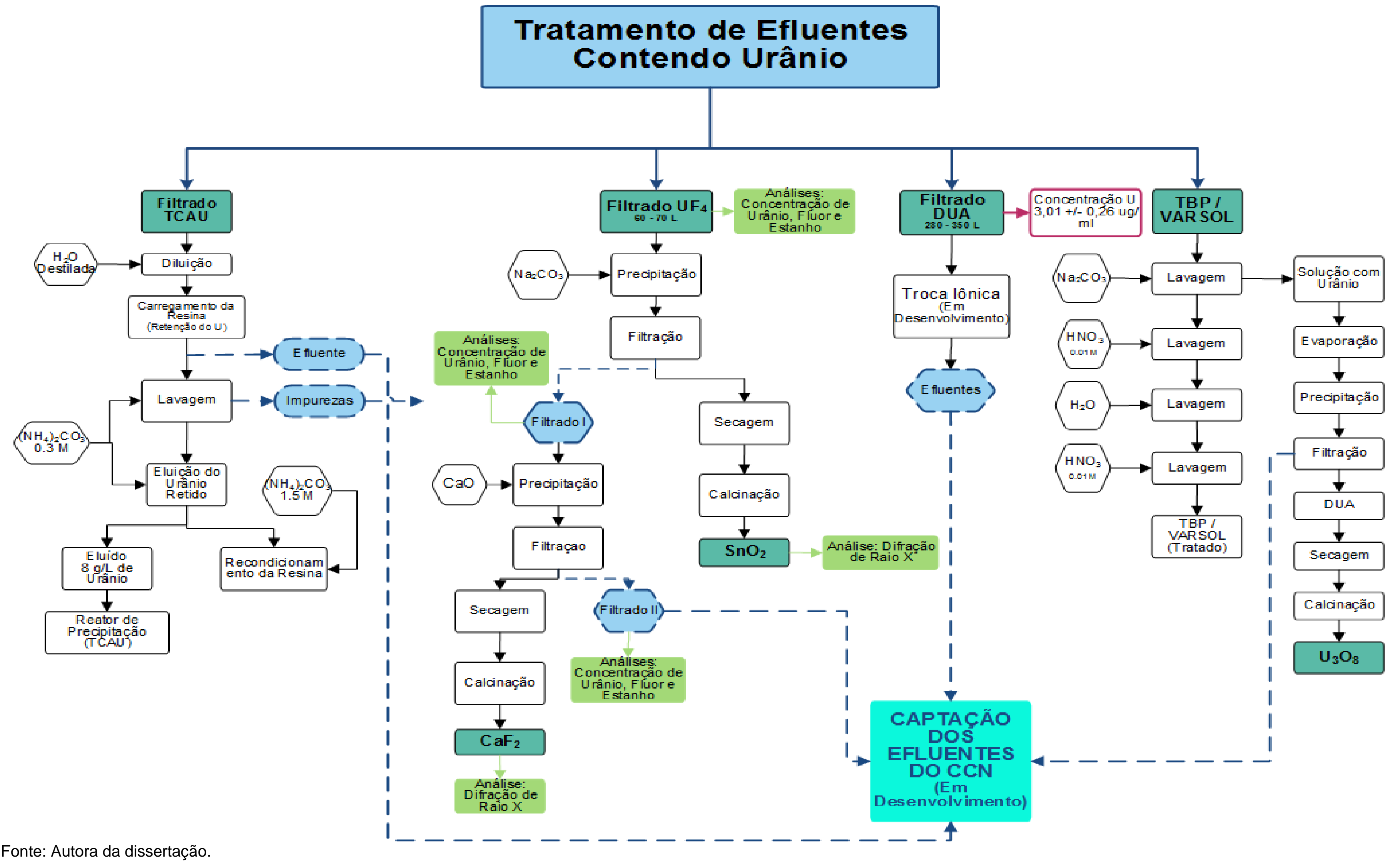




\subsection{Nova instalação do CCN}

A finalidade do Empreendimento Reator Multipropósito Brasileiro - RMB é disponibilizar para o país uma instalação nuclear com características e capacidade para prestar serviços de produção de radioisótopos, em especial o $\mathrm{Mo}^{99}$ para aplicação na medicina nuclear. O IPEN/CNEN-SP possui tecnologia e fabrica, no $\mathrm{CCN}$, combustível tipo placa nas características necessárias ao Empreendimento RMB.

Nos últimos anos o CCN vem melhorando sua infraestrutura predial, agrupando parte do processo fabril e dos laboratórios que se encontravam localizado de forma descentralizado no sítio do IPEN/CNEN-SP. A nova instalação do CCN visa atender a nova demanda, tendo como cliente o RMB, com todo processo fabril operando de modo integrado, na qual todas as atividades de fabricação sejam realizadas sob um plano mais coerente. A infraestrutura do local foi projetada para uma capacidade máxima de produção de até 60 elementos combustíveis por ano, com um regime de produção em até três turnos. O CCN é composto das seguintes edificações, que abrigam as suas unidades:

- Prédio 96 (piso térreo e superior);

- Escritórios;

- Prédio 97(piso térreo e superior).

O prédio 96 é composto de duas áreas de processamento e seus respectivos setores como segue:

- CCR - Processamento Químico (Setor de Transferência do UF, Setor de Reconversão de $\mathrm{UF}_{6}$, Setor de Recuperação de Urânio e Setor de Tratamento de Efluentes industriais)

- CCL - Processamento Ligas Especiais: (Setor de Redução e Fusão de Ligas). 
O prédio 97 é composto de uma área com três setores como segue:

- CCP - Processamento Mecânico-Metalúrgico (Setor de Processamento de Pós e Briquetes, Setor de Fabricação de Placas e Montagem de EC e Setor de Metrologia e Controle de Processo). Entre o prédio 96 e 97 encontram-se escritórios e banheiros dos servidores do Centro e a área administrativa.

No piso superior do prédio 96 está sendo implantados laboratórios de caracterização química e física para que num futuro todas as análises de caracterização sejam realizadas no CCN. O piso superior do prédio 97 localizase 0 auditório, salas de técnicos, sistema de monitoração e Proteção radiológica.

O CCN possui ainda em sua estrutura, cabine de gases, caldeira elétrica, moto gerador, sistema de tratamento de água desionizada, cabine de força elétrica, oficina mecânica e almoxarifado.

A Figura 4.8 ressalta o setor de tratamento de efluentes (sólidos e líquidos) e gasosos representando na figura por círculos azuis como lavadores de gases instalados em cada setor (CCR, CCL e CCP). Também, com o intuito de ter um melhor gerenciamento dos efluentes gerados o prédio conta com tubulações e pias específicas para cada classe de efluente.

Os efluentes originados nas áreas que constituem o CCN são coletados, no local de origem, de forma segregada, de acordo com o estado físico, composição química e radiológica. Os rejeitos sólidos são coletados em recipientes com capacidade para 40 litros. Durante o tempo de coleta esses recipientes são mantidos em suportes plásticos identificados e posteriormente enviados para reciclagem ou tratamento. 
Figura 4.11 Nova instalação do CCN.

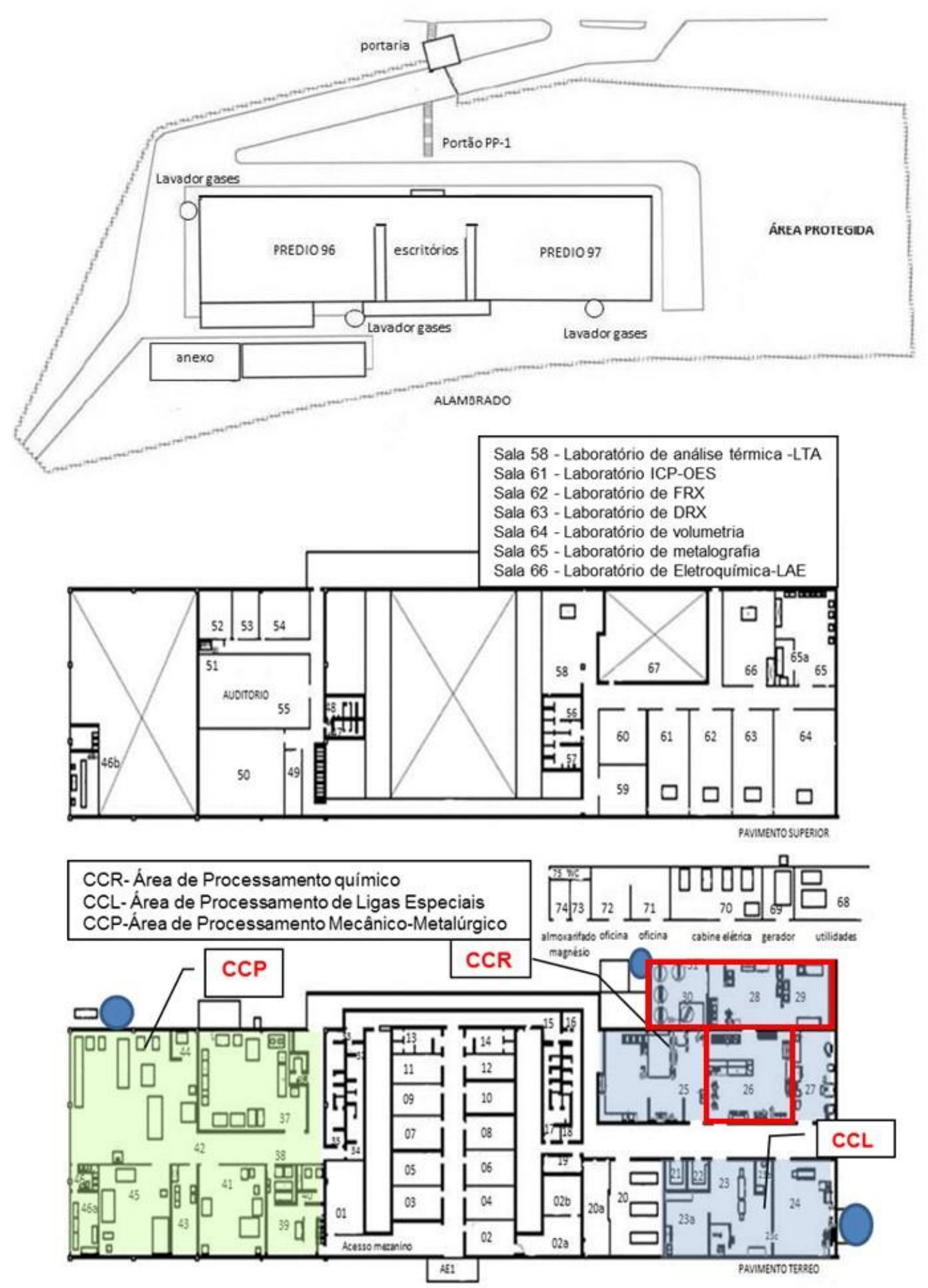

Fonte: Descrição das Atividades e Operações - Centro do Combustível Nuclear (2007). 
Para a classe de efluentes líquidos considera-se uma subdivisão em efluentes inorgânicos e orgânicos. Em função da classificação adotada, os efluentes são coletados e encaminhados para os tanques de armazenagem do Sistema de tratamento de efluentes do CCN. A segregação dos efluentes do CCN é obtida em função da instalação de pias e tubulações específicas para cada classe de efluente, ou seja, nas áreas onde há a possibilidade de geração de efluentes foram instaladas pias ligadas a tubulações independentes, para a coleta de efluentes.

Para os materiais radioativos são identificados com o símbolo de radiação e com informações sobre a origem, conteúdo, atividade, taxa de exposição e data. O restante dos materiais que são armazenados é etiquetado informando o lote, data, conteúdo da amostra, peso ou volume.

Para os efluentes sólidos e líquidos é prevista a sua armazenagem temporária, em tambores e tanques respectivamente, antes da destinação para a área de armazenagem ou tratamento local. Os tanques de armazenagem de efluentes líquidos ficam confinados em tanques de contenção em polietileno.

Os efluentes gasosos e líquidos são submetidos a processos de tratamento localizado, antes de sua liberação para o meio ambiente.

Na operação da Área de reconversão (transferência de $U_{6}$ e obtenção de tetrafluoreto de urânio - UF 4 ) são gerados efluentes gasosos contendo urânio somente em caso de ocorrência de algum evento anormal de operação. Nas operações da área de Reconversão do $U_{6}$ - Obtenção de $U_{4}$ e da área de Recuperação urânio proveniente dos refugos da fabricação (efluentes sólidos) gera uma corrente de efluentes gasosos apresentando uma composição de traços de $\mathrm{NH}_{3}$, NOx, HF e vapor d'água.

As correntes gasosas, contendo urânio ou não, são removidas das áreas geradoras por sistemas de exaustão e são geralmente conduzidas aos lavadores de gases. Nas salas 25, 25A e 25B, que se manipula $U_{6}$ na forma gasosa, é mantida a pressão das ligeiramente, inferior à atmosférica, o que impede a dispersão dos contaminantes para outras áreas. 
Os efluentes originados no CCN são submetidos a procedimentos de monitoração adequados em todas as etapas de gerenciamento. A monitoração é feita pelas áreas de proteção radiológica e controle ambiental.

A operação de liberação, para o meio ambiente, de efluentes líquidos tratados é feita de forma controlada, visando o atendimento aos padrões de emissão estabelecidos pela CNEN e demais órgão de controle ambiental. 


\section{Conclusões}

De acordo com os resultados apresentados, pode-se concluir que:

1. A área nuclear é um campo de pesquisa muito vasto em todos os seus aspectos. No aspecto ambiental a caracterização dos efluentes gerado no processo de produção de combustível nuclear tipo MTR permitiu conhecer melhor sua carga contaminante, sendo os principais urânio, fluoreto e amônia.

2. Foi possível quantificar os efluentes gerados no processo de produção do EC, e também caracterizar química e fisicamente os efluentes líquidos, gasosos e sólidos gerados no processo facilitando 0 gerenciamento ambiental.

3. Os efluentes gasosos gerados no processo de fabricação são coletados através de captores individuais em lavadores de gases. O controle químico é realizado de 3 em 3 meses e posteriormente liberado ao meio ambiente, sem causar contaminação.

4. Os resultados encontrados a partir da análise dos critérios de significância de impactos ambientais confirmam que os principais aspectos que podem causar contaminação ao meio ambiente, são os efluentes líquidos. Mas, caso realize-se um gerenciamento mais definido desses efluentes os critérios de significância de impactos ambientais poderiam atingir um índice menor diminuindo as chances de causar contaminação ao meio ambiente.

5. O processo de controle de efluentes líquidos é bastante significativo, pois apresenta tratamento, seja para atender as conformidades para realizar o descarte ou recuperar o urânio para voltar ao processo. 30\% do efluente líquido possuem tratamento de recuperação de urânio retornando ao processo produtivo gerando efluente convencional onde a unidade de tratamento está sendo implantado. $20 \%$ dos efluentes líquidos são reutilizados na composição química em que foi gerado, 35\% descartado diretamente ao meio ambiente de acordo com a legislação. O restante dos efluentes líquidos, cerca de $15 \%$, estão em fase de desenvolvimento do processo de tratamento. 
6. Dos efluentes sólidos gerados cerca de $90 \%$ contem urânio, sendo $55 \%$ tratado e recuperado o urânio, retornando ao processo produtivo. 0 único efluente sólido reciclado e isento de urânio são os retalhos de alumínio 6061 . O restante está em fase de desenvolvimento do processo de tratamento.

7. O TBP/isoparafina é o único efluente que após tratamento e reuso por um período de 4 bateladas torna-se rejeito radiativo, com concentração de urânio de 10,2 $\pm 0,3 \mu \mathrm{g} \cdot \mathrm{mL}^{-1}$

8. Com a identificação dos aspectos ambientais que teriam maior chance de contaminar o meio ambiente, algumas ações foram implementadas no processo de produção do combustível nuclear. Como exemplo, podese citar o método de avaliação das placas combustíveis, anteriormente realizadas por um processo químico que utilizava revelação de filmes radiográficos e geração de efluentes líquidos, atualmente fazendo uso de scanner radiográfico isento de efluentes. 


\section{Referências Bibliográficas}

[1] DURAZZO, M., CARVALHO, E. F. U., SILVA A, M. S., SOUZA, J. A. B.; RIELLA H, G. Fabricação de elementos combustíveis a base de $U_{3} \mathrm{Si}_{2}$ no Brasil. Revista Brasileira de Pesquisa e Desenvolvimento, v.9, n.1 p.18-28, 2007.

[2] Ministério da Ciência e da Tecnologia. Ciência, Tecnologia e Inovação para o Desenvolvimento Nacional - Plano de ação. Brasília, 20072010.

[3] MEDICINA NUCLEAR EM REVISTA: 0 especialista. São Paulo: Sociedade Brasileira de Medicina Nuclear, v. 5, jan. 2014. Trimestral. Disponível

em:

<http://rspress.com.br/userfiles/projetos/editorial_305/files/assets/basichtml/page1.html>. Acesso em: 20 set. 2017.

[4] JECKEL, Cristina M Moriguchi. O que é um radiofármaco? Para que serve? Disponível em: <http://inscer.pucrs.br/artigo-o-que-e-umradiofarmaco-para-que-serve-profa-dra-cristina-m-moriguchi-jeckelpesquisadora-do-inscer/>. Acesso em: 20 set. 2017.

[5] RIO DE JANEIRO. COMISSÃO NACIONAL DE ENERGIA NUCLEAR. (Org.). Com Reator Multipropósito, Brasil terá autonomia na produção de radioisótopos. 2016. Disponível em: <http://www.cnen.gov.br/ultimasnoticias/249-com-reator-multiproposito-brasil-tera-autonomia-naproducao-de-radioisotopos>. Acesso em: 20 set. 2017.

[6] IPEN, INSTITUTO DE PESQUISAS ENERGÉTICAS E NUCLEARES. Implantação de um Centro de Processamento de Combustíveis no IPEN - Plano Diretor. Departamento do Ciclo do Combustível. Relatório Interno MC.PT.0001.97.0. São Paulo, p. 35, 1997.

[7] CNEN. COMISSÃO NACIONAL DE ENERGIA NUCLEAR. Licenciamento de Instalações Nucleares. Norma CNEN-NE-1.04. Dezembro de 2002. 
[8] BRASIL, Resolução CONAMA n 237, de 22 de dezembro de 1997. Regulamenta os aspectos de licenciamento ambiental estabelecidos na Política Nacional do Meio Ambiente. Publicação DOU n² 247. p.30.841-30.843, 1997.

[9] IPEN, INSTITUTO DE PESQUISAS ENERGÉTICAS E NUCLEARES. Diretoria de Planejamento e Inovação - Plano Diretor. Relatório Interno, São Paulo, 2005.

[10] IPEN, INSTITUTO DE PESQUISAS ENERGÉTICAS E NUCLEARES, Disponível em: <https://www.ipen.br/portal_por/portal/interna.php?secao_id=544> Acesso em: 27/09/2017.

[11] IPEN, INSTITUTO DE PESQUISAS ENERGÉTICAS E NUCLEARES. Descrição das Atividades e Operações - Centro do Combustível Nuclear (CCN), Relatório Interno, São Paulo, 2007.

[12] MATTOS, L. A. T. Proposta metodológica para a identificação e avaliação de aspectos e impactos ambientais em instalações nucleares do IPEN: estudo de caso aplicado ao centro do Combustível Nuclear. Tese (Doutorado), Instituto de Pesquisas Energéticas e Nucleares / Universidade de São Paulo, São Paulo, 2008.

[13] RUPPENTHAL, J. E., Gestão Ambiental, Universidade Federal de Santa Maria, Colégio Técnico Industrial de Santa Maria, Rede e-Tec Brasil, 2014.

[14] NASCIMENTO, L. F. Gestão Ambiental e Sustentabilidade, Gestão Ambiental Sustentabilidade Miolo Grafica.indd, Florianópolis, 2012.

[15] SPAZZANI, M. L., SILVA, P. G. F. Planejamento e Avaliação em Projetos de Educação Ambiental, IESDE BRASIL S.A, 2012.

[16] GOUVÊA, Y. M. G., ACKER, F. T. V. Gestão e Tecnologias Ambientais: Legislação Ambiental. MBA-USP "Programa de Educação Continuada". Universidade de São Paulo, São Paulo, 2002.

[17] BRASIL. Lei no 6.938, de 31 de agosto de 1981(Diário Oficial). Dispõe sobre a Política Nacional do Meio Ambiente, seus fins mecanismos 
de formulação e aplicação, e dá outras providências Ministério da Ciência e Tecnologia, 1981.

[18] BRASIL, Resolução CONAMA n 001/86, de 23 de janeiro de 1986, Critérios básicos e diretrizes gerais para uso e implementação da avaliação de impacto ambiental. Publicação DOU, 1986.

[19] CNEN, COMISSÃO NACIONAL DE ENERGIA NUCLEAR (CNEN). Diretrizes Básicas de Radioproteção, CNEN-NE-3.01, 19 de julho de 1988.

[20] SILVA NETO, J. B. Processo alternativo para obtenção de tetrafluoreto de urânio a partir de efluentes fluoretados da etapa de reconversão de urânio. Dissertação (Mestrado), Instituto de Pesquisas Energéticas e Nucleares / Universidade de São Paulo, São Paulo, 2008.

[21] BRASIL, Resolução CONAMA n 357, de 18/03/2005. Classificação dos corpos de água e diretrizes ambientais. Publicação DOU $\mathrm{n}^{\circ} 357$. p.58-63, 2005.

[22] BRASIL, Resolução CONAMA $n^{\circ} 430$, de 13 de maio de 2011, Condições e padrões de lançamento de efluentes. Publicação DOU no $430,2005$.

[23] Guia de Terminologia Ambiental sobre tratamento de efluentes e resíduos. 2013. Disponível em: <http://www.teraambiental.com.br/blogda-tera-ambiental/bid/252991/guia-de-terminologia-ambiental-sobretratamento-de-efluentes-e-residuos>. Acesso em: 27 set. 2017.

[24] CNEN. COMISSÃO NACIONAL DE ENERGIA NUCLEAR. Licenciamento de Instalações Radiativas. Norma CNEN-NE-6.02. Abril de 2002.

[25] NA/NRC. Analysis Of Cancer Risks In Populations Near Nuclear Facilities: Phase 1. Washigton DC: National Academies Press; 2012. Available at www.nap.edu/catalog.php?record_id=13388. Accessed 24 May 2013. 
[26] WING S., RICHARDSON D. B., HOFFMANN W. Cancer Risks Near Nuclear Facilities: The Importance Of Research Design And Explicit Study Hypotheses. Environ Health Perspect; 2010.

[27] JABLON S., HRUBEC Z., BOICE J. D. Jr. Cancer In Populations Living Near Nuclear Facilities. A Survey Of Mortality Nationwide And Incidence In Two States.1991.

[28] KONG et al. Radioactive Effluents Released From Korean Nuclear Power Plants And The Resulting Radiation Doses To Members Of The Public. Nuclear Engineering And Technology. República da Coréia, p. 1-6. 28 jul. 2017.

[29] Gerenciamento De Efluentes E Rejeitos Radioativos Oriundos Da Geração De Energia Nuclear. Disponível em: <http://www.iaea.org/inis/collection/NCLCollectionStore/_Public/44/079/4 4079091.pdf>. Acesso em: 20 set. 2017.

[30] AIEA. Nuclear Techonology Review 2016(Report), Vienna. 2016.

[31] AMFT, M.; LEISVIK, M.; CARROLL, S. Applying And Adapting The Swedish Regulatory System For Decommissioning To Nuclear Power Reactors E The Regulator's Perspective. Journal Of Environmental Radioactivity. Suécia, p. 1-6. 07 mar. 2017.

[32] SEO et al. Proposal For The Management Strategy Of Metallic Waste From The Decommissioning Of Kori Unit 1 By Using Melting And Segmentation Technology. Annals Of Nuclear Energy. República da Coréia, p. 633-647. 29 jun. 2017.

[33] KIM, J.; KIM, C. Performance Improvement of Liquid Waste Management System for APR1400. Progress In Nuclear Energy. Coréia do Sul, p. 93-102. 25 maio 2017

[34] GARCIA, D. Z.; WERSHOFEN, H. Development Of Radiochemical Analysis Strategies For Decommissioning Activities. Applied Radiation And Isotopes. Alemanha, p. 204-207. 27 fev. 2017.

[35] PLAGNES et al. Water Balance Modelling Of A Uranium Mill Effluent Management System. Journal Of Hydrology. Canada, p. 741-753. 24 
mar. 2017.

[36] OTHMAN et al. Adsorption Of Hazardous lons From Radioactive Waste On Chelating Cloth Filter. Radiatioin Physics And Chemistry. Egito, p. 1-8. 27 ago. 2005.

[37] CHAUDHURY, S.; MUDHER, K. D. S.; VENUGOPAL, V. Recovery Of Uranium From Fluoride Matrix By Solid State Reaction Routes. Journal Of Nuclear Materials. India, p. 1-7. 24 jun. 2003.

[38] CARVALHO et al. Manufacturing Low Enriched Uranium Metal By Magnesiothermic Reduction Of UF4. Annals Of Nuclear Energy. São Paulo, p. 874-885. 28 jul. 2017.

[39] KUSHWAHA S., SUDHAKAR P. P. Sorção De Urânio A Partir De Soluções Aquosas Usando Adsorventes À Base De Palma: Estudo Cinético E De Equilíbrio. J. Environ. Radiogr, 126 (2013), pp. 115 - 124.

[40] YAKOUT S. M., METWALLY S. S., EL-ZAKLA T. Sorção De Urânio Em Carvão Ativado Preparado A Partir De Palha De Arroz: Competição Com Ácidos Húmicos. Appl. Surf. Sci., 280 (2013), pp. 745 - 750.

[41] ROONGTANAKIAT N., SUDSAWAD P., NGERNVIJIT N. Capacidade De Absorção De Urânio De Girassol, Vetiver E Grama De Guiné Roxa. Kasetsart J. Nat. Sci., 44 (2010), pp. $182-190$.

[42] QADEER R., HANIF J. Cinética De Urânio (VI) Adsorção De Carvão Ativado A Partir De Soluções Aquosas. Radiochim. Acta, 65 (1994), pp. $259-263$.

[43] MAHMOUD A. Avaliação Da Remoção De Urânio Da Solução Aquosa Usando Cascas De Laranja No Sistema De Cama Fixa. Chem. Eng. Process Tech., (2014), p. 5.

[44] RULE P., GONTE R. R. Uranium (VI) De Remediação De Ambiente Aquoso Usando Contas De Celulose Impregnadas. Environ. Radiogr., 36 (2014), pp. 22 - 29.

[45] SENEDA et al. Recovery of uranium from the filtrate of 'ammonium diuranate' prepared from uranium hexafluoride. Alloys And Compounds. São Paulo, p. 838-841. out. 2001. 
[46] BLEISE A., DANESI P. R., BURKART W. Propriedades, Uso E Efeitos Da Saúde Do Urânio Empobrecido (DU): Uma Visão Geral. Environ. Radiol., (2003), pp. 93 - 112.

[47] KABAY N., EGAWA H. Avanços Recentes No Desenvolvimento De Polímeros Quelatantes Para Recuperação De Urânio Da Água Do Mar. Doga-Tr. J. Chem., 17 (1993), pp. 62 - 73.

[48] SANTOS, R. M. S. et al. O Gerenciamento de resíduos sólidos e efluentes na indústria: aspectos ambientais, econômicos, sociais e estratégicos. Educação Ambiental em Ação, Amazonas, v. 41, p.1-12, set. 2012.

[49] MIERZWA, José Carlos; HESPANHOL, Ivanildo. Programa Para Gerencimento De Águas E Efluentes Nas Indústrias, Visando O Uso Racional E A Reutilização. Engenharia Sanitária e Ambiental, São Paulo, v. 4, n. 2, p.11-15, abr. 2000.

[50] TERA AMBIENTAL (Org.). Como funciona o tratamento de efluentes industriais. 2013. Disponível em: $<$ http://www.teraambiental.com.br/blog-da-teraambiental/bid/338190/como-funciona-o-tratamento-de-efluentesindustriais>. Acesso em: 20 set. 2017. 